\title{
Genetic Basis of Human Congenital Heart Disease
}

\author{
Shannon N. Nees ${ }^{1}$ and Wendy K. Chung ${ }^{1,2}$ \\ ${ }^{1}$ Department of Pediatrics, ${ }^{2}$ Department of Medicine, Columbia University Irving Medical Center, New York, \\ New York 10032, USA \\ Correspondence:Wkc15@cumc.columbia.edu
}

Congenital heart disease (CHD) is the most common major congenital anomaly with an incidence of $\sim 1 \%$ of live births and is a significant cause of birth defect-related mortality. The genetic mechanisms underlying the development of $\mathrm{CHD}$ are complex and remain incompletely understood. Known genetic causes include all classes of genetic variation including chromosomal aneuploidies, copy number variants, and rare and common singlenucleotide variants, which can be either de novo or inherited. Among patients with CHD, $\sim 8 \%-12 \%$ have a chromosomal abnormality or aneuploidy, between $3 \%$ and $25 \%$ have a copy number variation, and $3 \%-5 \%$ have a single-gene defect in an established $\mathrm{CHD}$ gene with higher likelihood of identifying a genetic cause in patients with nonisolated CHD. These genetic variants disrupt or alter genes that play an important role in normal cardiac development and in some cases have pleiotropic effects on other organs. This work reviews some of the most common genetic causes of CHD as well as what is currently known about the underlying mechanisms.

C ongenital heart disease (CHD) is the most common major congenital anomaly with an incidence of $\sim 1 \%$ of live births (Hoffman and Kaplan 2002; Calzolari et al. 2003). CHD is a significant cause of birth defect-related mortality (Hanna et al. 1994; Lee et al. 2001; Hoffman and Kaplan 2002; Calzolari et al. 2003; Centers for Disease Control and Prevention (CDC) 2007; van der Linde et al. 2011; Gilboa et al. 2016). CHD encompasses any malformation of the cardiovascular system present at birth, and there are many subtypes ranging from relatively simple lesions such as atrial and ventricular septal defects to complex lesions such as hypoplastic left heart syndrome (HLHS) in which there are underdeveloped left-sided cardiac structures and only a single functioning ventricle. The high concordance in monozygotic twins, the increased risk of recurrence in first-degree relatives compared with the general population, and genetic syndromes associated with specific types of $\mathrm{CHD}$ all suggest a genetic component to $\mathrm{CHD}$ in at least some cases (Nora et al. 1988). The genes and genetic mechanisms underlying $\mathrm{CHD}$ are complex and remain incompletely understood, but our understanding has improved significantly over the past decade. All classes of genetic variation including chromosomal aneuploidies, copy number variants $(\mathrm{CNVs})$, and rare and common de novo and inherited single-nucleo-

Editors: Benoit G. Bruneau and Paul R. Riley

Additional Perspectives on Heart Development and Disease available at www.cshperspectives.org

Copyright (C) 2020 Cold Spring Harbor Laboratory Press; all rights reserved; doi: 10.1101/cshperspect.a036749

Cite this article as Cold Spring Harb Perspect Biol 2020;12:a036749 
tide variants (SNVs) contribute to CHD (Thienpont et al. 2007; Erdogan et al. 2008; Southard et al. 2012; Gelb and Chung 2014). These genetic variants disrupt or alter genes that play an important role in normal cardiac development. Although many of the genes and mutations that increase the risk of developing CHD have been identified, only $\sim 20 \%-30 \%$ of individuals with CHD have an identifiable single genetic factor, and this yield varies significantly by cardiac lesion and whether there are additional medical features besides CHD (Grech and Gatt 1999; Gelb 2004; Cowan and Ware 2015; Patel et al. 2016). This work reviews the most common genetic causes of $\mathrm{CHD}$ as well as the known genetic mechanisms.

\section{OVERVIEW OF CHD}

$\mathrm{CHD}$ is the most common birth defect affecting $\sim 1 \%$ of live births, or up to $3 \%$ of live births in studies that include bicuspid aortic valve (BAV) (Hoffman and Kaplan 2002; Calzolari et al. 2003; Tutar et al. 2005; van der Linde et al. 2011; Egbe et al. 2014). CHD encompasses a wide spectrum of defects, with varying physiologic consequences. More severe lesions that require multiple surgeries have an incidence of $\sim 0.1 \%$ of live births (Bernier et al. 2010). Despite significant advances in clinical care, CHD remains the leading cause of birth defect-related mortality (Boneva et al. 2001; Lee et al. 2001; Marelli et al. 2007; Gilboa et al. 2010; Khairy et al. 2010). Data from the Metropolitan Atlanta Congenital Heart Defects Program showed a 1yr survival of $83 \%$ for patients with critical CHD (Oster et al. 2013). For those patients who survive through infancy, there are still significant lifelong morbidities (Oster et al. 2013; Agarwal et al. 2014).

\section{EVIDENCE FOR THE GENETIC BASIS OF CHD}

The etiology of $\mathrm{CHD}$ is multifactorial. A genetic or environmental cause can be identified in $\sim 20 \%-30 \%$ of all cases, and that number is changing as new methods of testing become available (Grech and Gatt 1999; Gelb 2004; Cowan and Ware 2015; Patel et al. 2016).
The overall incidence of CHD is similar between males and females; however, there are differences by type of CHD with males having a slightly higher incidence of more severe lesions (Sampayo and Pinto 1994; Moons et al. 2009). There are also differences in incidence of specific lesions based on race and ethnicity. Patent ductus arteriosus (PDA) and ventricular septal defects (VSDs) are more common in Europeans, whereas atrial septal defects (ASDs) are more common in Hispanics (Fixler et al. 1990; Egbe et al. 2014). The differences observed based on gender and race suggest that genetics play an important role in the development of specific types of CHD, with certain populations having increased genetic susceptibility.

The risk of CHD recurrence in the offspring of an affected parent is between 3\% and 20\% depending on the lesion. Recurrence risk in the offspring of women with CHD is about twice as high as the recurrence in offspring of men with CHD (Burn et al. 1998). A study from Northern Ireland found that the risk of recurrence of $\mathrm{CHD}$ for siblings was $3.1 \%$, and siblings had an increased risk of extracardiac anomalies even in the absence of CHD (Hanna et al. 1994). Other studies have shown similar risk of recurrence among siblings; more severe types of $\mathrm{CHD}$ have higher recurrence rates (Calcagni et al. 2006; Øyen et al. 2009; Brodwall et al. 2017). Lesions with the highest recurrence risk are heterotaxy (HTX), right ventricular outflow tract obstruction, and left ventricular outflow tract obstruction (Loffredo et al. 2004). Approximately one-half of siblings with recurrent $\mathrm{CHD}$ have a different lesion, supporting the theory that the etiology of CHD is multifactorial (Oyen et al. 2010). Table 1 describes the estimated recurrence risk for $\mathrm{CHD}$ by lesion and affected family member.

Overall, twins have an increased risk of $\mathrm{CHD}$ compared with singleton pregnancies, which is thought to be the result of vascular changes related to a shared placenta (Manning and Archer 2006; Herskind et al. 2013; Best and Rankin 2015). A population-based Taiwanese study calculated the adjusted risk ratio for $\mathrm{CHD}$ with an affected relative and found that it was 12.03 for a twin, 4.91 for a first-degree relative, and 1.21 for 
Table 1. Risk of recurrence for common isolated congenital heart disease

\begin{tabular}{lcccc}
\hline Lesion & Father affected $(\%)$ & Mother affected (\%) & One sibling affected (\%) & Two siblings affected (\%) \\
\hline ASD & $1.5-3.5$ & $4-6$ & $2.5-3$ & 8 \\
AVSD & $1-4.5$ & $11.5-14$ & $3-4$ & 10 \\
VSD & $2-3.5$ & $6-10$ & 3 & 10 \\
AS & $3-4$ & $8-18$ & 2 & 6 \\
PS & $2-3.5$ & $4-6.5$ & 2 & 6 \\
TOF & 1.5 & $2-2.5$ & $2.5-3$ & 8 \\
CoA & $2-3$ & $4-6.5$ & 2 & 6 \\
HLHS & 21 & 21 & $2-9$ & 6 \\
D-TGA & 2 & 2 & 1.5 & 5 \\
\hline
\end{tabular}

Data adapted from Cowan and Ware (2015).

See Nora et al. (1988); Nora (1994); Calcagni et al. (2006); Hinton et al. (2007).

(AS) Aortic stenosis, (ASD) atrial septal defect, (AVSD) atrioventricular septal defect, (CoA) coarctation of the aorta, (D-TGA) d-loop transposition of the great arteries, (HLHS) hypoplastic left heart syndrome, (PS) pulmonary stenosis, (TOF) tetralogy of Fallot, (VSD) ventricular septal defect.

a second-degree relative. They determined that the phenotypic variance of CHD was $37.3 \%$ for familial transmission and $62.8 \%$ for non-shared environmental factors (Kuo et al. 2018). In a large Norwegian birth cohort study, the adjusted relative risk ratio of $\mathrm{CHD}$ for siblings of a child with CHD was 14.0 for same-sex twins, 11.9 for opposite-sex twins, 3.6 for full siblings, and 1.5 for half siblings (Brodwall et al. 2017). These data suggest a genetic component, although there is also higher incidence of CHD in dizygotic twins compared with non-twin siblings suggesting an environmental component in addition (Caputo et al. 2005).

\section{GENETIC TESTING IN CONGENITAL HEART DISEASE}

When a genetic cause of CHD is identified, this knowledge can assist clinical management by identifying other organ systems that should be screened for structural or functional problems and by facilitating predictions about future complications and prognosis (Pierpont et al. 2007). Identification of a genetic etiology, which may be inherited or de novo, allows for more accurate estimation of recurrence risk. Despite the importance of identifying a genetic cause in patients with $\mathrm{CHD}$, current genetic testing practices are quite variable (Cowan and Ware 2015).

Genetic testing for a fetus with CHD can start in the prenatal period with either chorionic villus sampling (CVS) at 10-11 wk gestation or amniocentesis after 15-16 wk gestation to obtain placental/fetal DNA. More recently, noninvasive prenatal testing (NIPT) has been used to obtain fetal cell-free DNA from maternal blood to screen for aneuploidies and common deletions or duplications, most notably 22q11.2 deletion syndrome (Wapner et al. 2015; Grace et al. 2016; Dugoff et al. 2017; Gil et al. 2017). NIPT is a screening test, and abnormal findings require confirmatory testing using chorionic villi, amniocytes, or postnatal testing.

Clinical genetic testing in infants with CHD using karyotyping, fluorescence in situ hybridization (FISH), and chromosome microarray analysis (CMA) has an overall clinical yield of $15 \%-25 \%$ with a higher likelihood of finding a genetic diagnosis in patients with dysmorphic facial features and extracardiac anomalies (Breckpot et al. 2010, 2011; Baker et al. 2012; Al Turki et al. 2014; Connor et al. 2014; Ahrens-Nicklas et al. 2016). Karyotyping is a test performed on metaphase chromosomes that allows for the identification of aneuploidies and large chromosomal rearrangements. CMA is used to detect CNVs across the genome and can reliably detect deletions or duplications as small as $\sim 100,000$ nucleotides. If a specific deletion or duplication syndrome is suspected, FISH can be used and allows for rapid turnaround and focused testing. It is most commonly used to test for 22q11.2 deletion. 
Recent decreases in sequencing cost allow for more comprehensive assessment of the genome and have powered gene panel testing, whole-exome sequencing (WES), and wholegenome sequencing (WGS). For each of these tests, significant bioinformatics analysis is required after sequencing to determine the significance of the variant in each individual patient, often using data from family members to assess for the inheritance status and segregation with $\mathrm{CHD}$ in the family. WES targets the proteincoding regions, which comprise $\sim 1.5 \%$ of the genome, and has been particularly useful in assessing patients with $\mathrm{CHD}$ and extracardiac features (Gelb et al. 2013; Glessner et al. 2014; Homsy et al. 2015; LaHaye et al. 2016; Sifrim et al. 2016). WES is used increasingly in clinical practice because CHD is so genetically heterogeneous and because our knowledge of CHD genetics is incomplete (Bamshad et al. 2011). The yield of WES for CHD in the clinical setting of a single large genetic reference laboratory was 28\% (Retterer et al. 2016). The impact of having these genetic diagnoses on clinical care has not yet been elucidated. WGS sequences the entire genome including noncoding regions, but studies have not yet shown the additional clinical utility of WGS in patients with CHD, although this is an area of active investigation.

All of the tests described have limitations in terms of their detection and potential to identify variants of unknown significance, which may be difficult for both clinicians and patients to interpret. For this reason, it is important for cardiologists, medical geneticists, and genetic counselors to work together to decide the most appropriate testing and to interpret the results and explain them to the patient and their family.

\section{CHROMOSOMAL ANEUPLOIDIES}

Aneuploidy is an abnormal number of chromosomes such as a trisomy. The risk of most aneuploidies increases with increasing maternal age. In the Baltimore-Washington Infant study, chromosomal abnormalities were identified $>100$ times more frequently in patients with CHD compared with normal controls with a total of $12.9 \%$ of CHD cases having chromosomal abnormalities (Ferencz et al. 1989). The following sections review some of the most common aneuploidy syndromes associated with $\mathrm{CHD}$. Additional data on prevalence, types of $\mathrm{CHD}$, and associated features for each syndrome, as well as details on additional syndromes, are included in Table 2.

\section{Down Syndrome}

Down syndrome is the most common chromosomal abnormality found in patients with $\mathrm{CHD}$ and is usually caused by complete trisomy 21 (Hartman et al. 2011; de Graaf et al. 2016, 2017). CHD is found in $40 \%-50 \%$ of patients with Down syndrome, most commonly atrioventricular septal defect (AVSD) in $~ 40 \%$ followed by VSD, ASD, PDA, and tetralogy of Fallot (TOF) (Freeman et al. 2008; Allen et al. 2013).

CHD is a common cause of mortality in patients with Down syndrome, contributing to $13 \%$ of deaths in childhood and $23 \%$ of deaths in adulthood (Bittles et al. 2007). Some studies suggest that individuals with Down syndrome have worse outcomes after congenital heart surgery compared with those with no chromosomal abnormalities (Reller and Morris 1998; Landis et al. 2016). More recently, studies have shown equal or decreased risk of in-hospital mortality for patients with Down syndrome undergoing repair of CHD compared with patients with normal karyotypes except among patients with single ventricle physiology (Anaclerio et al. 2004; Formigari et al. 2004; Michielon et al. 2006, 2009; Lange et al. 2007; Evans et al. 2014; St Louis et al. 2014; Tumanyan et al. 2015). Although Down syndrome does not seem to confer an increased risk of mortality for most patients undergoing CHD repair, there is increased morbidity including increased length of stay, frequency of pulmonary hypertension, and other postoperative complications (Malec et al. 1999; Ip et al. 2002; Fudge et al. 2010; Lal et al. 2013).

\section{Trisomy 18 and 13}

Many fetuses with trisomy 13 or 18 do not survive to birth; however, among those who do, $\mathrm{CHD}$ is common. Ninety-five percent of pa- 
Genetic Basis of Human CHD
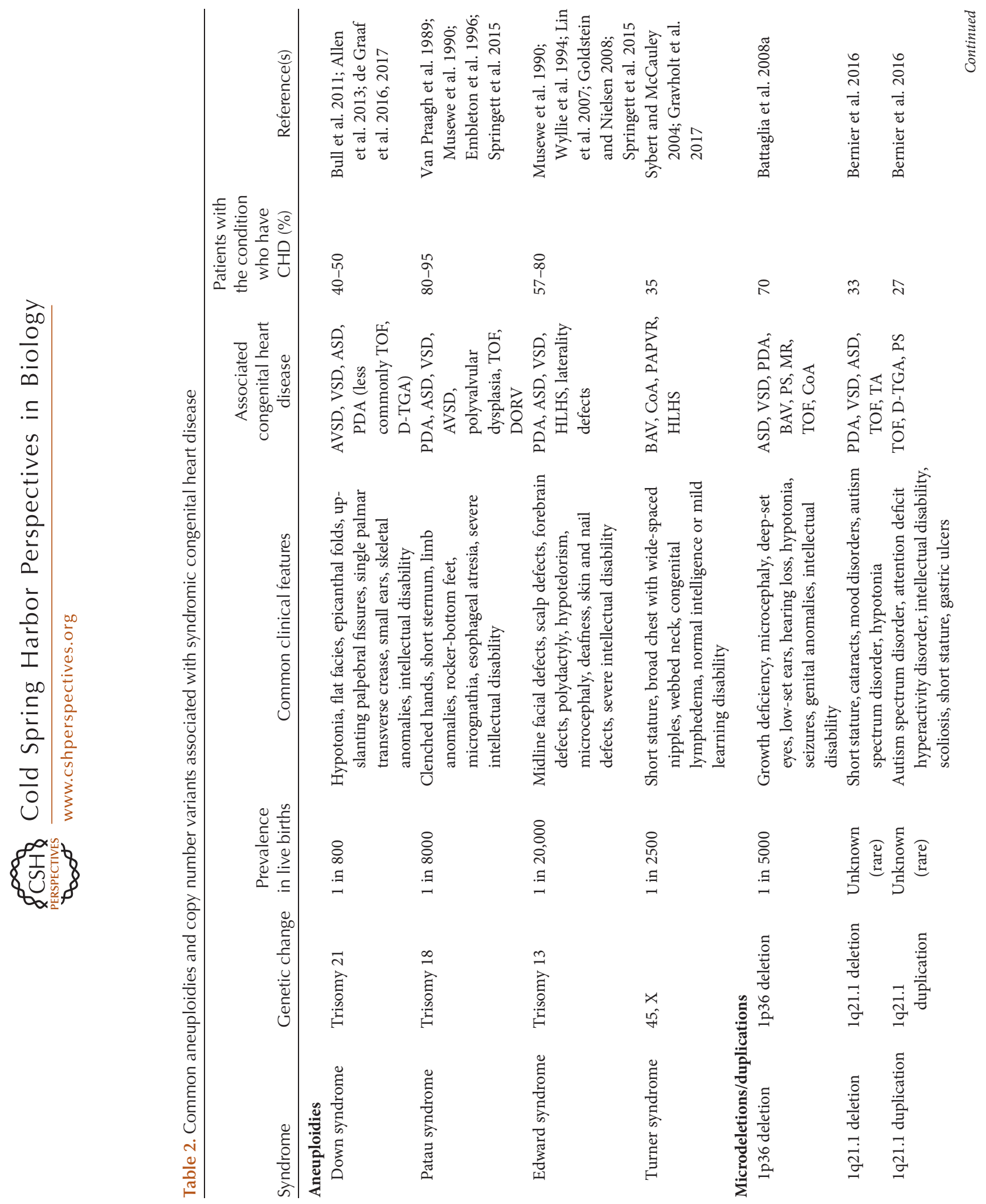
S.N. Nees and W.K. Chung
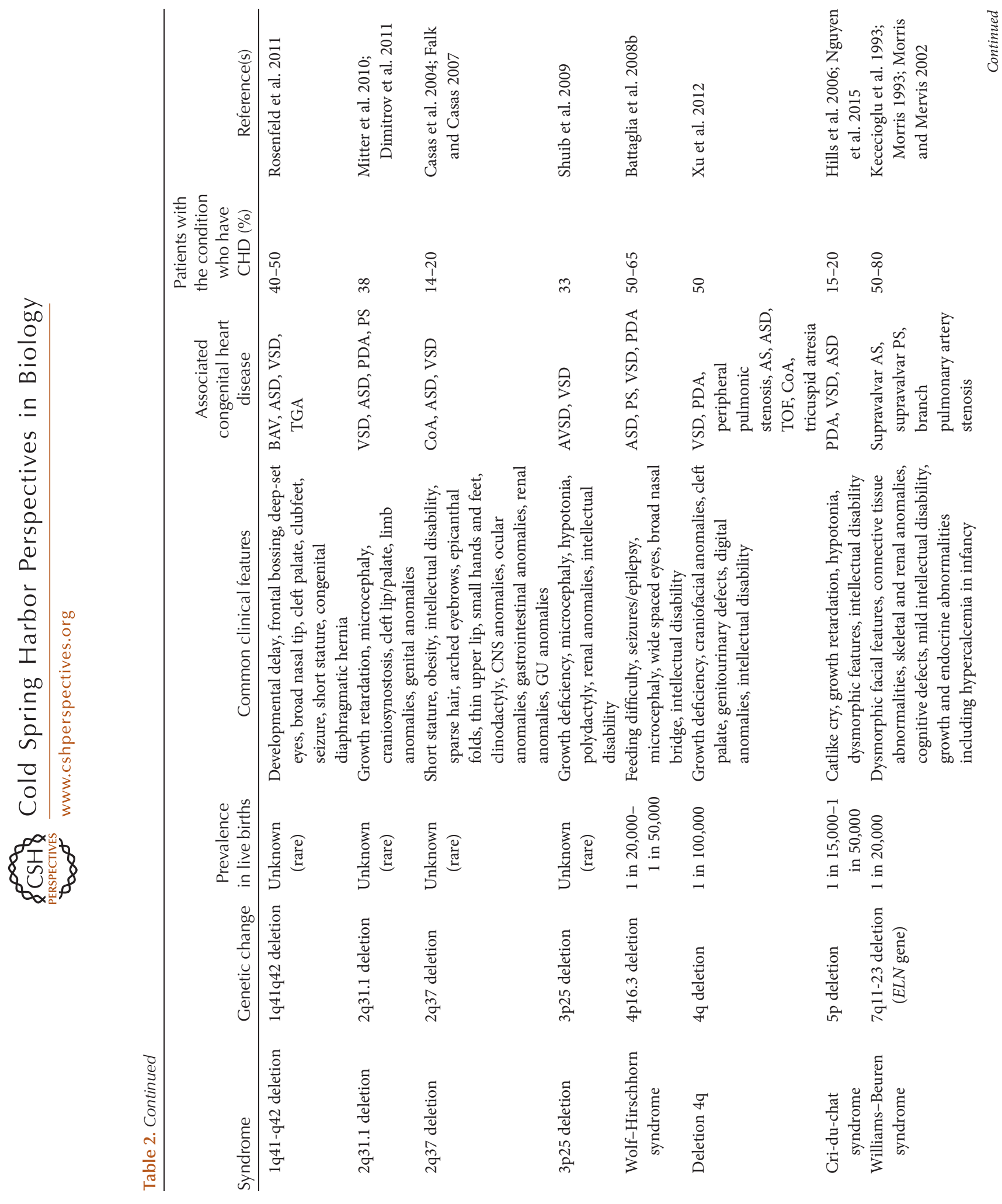
Genetic Basis of Human CHD
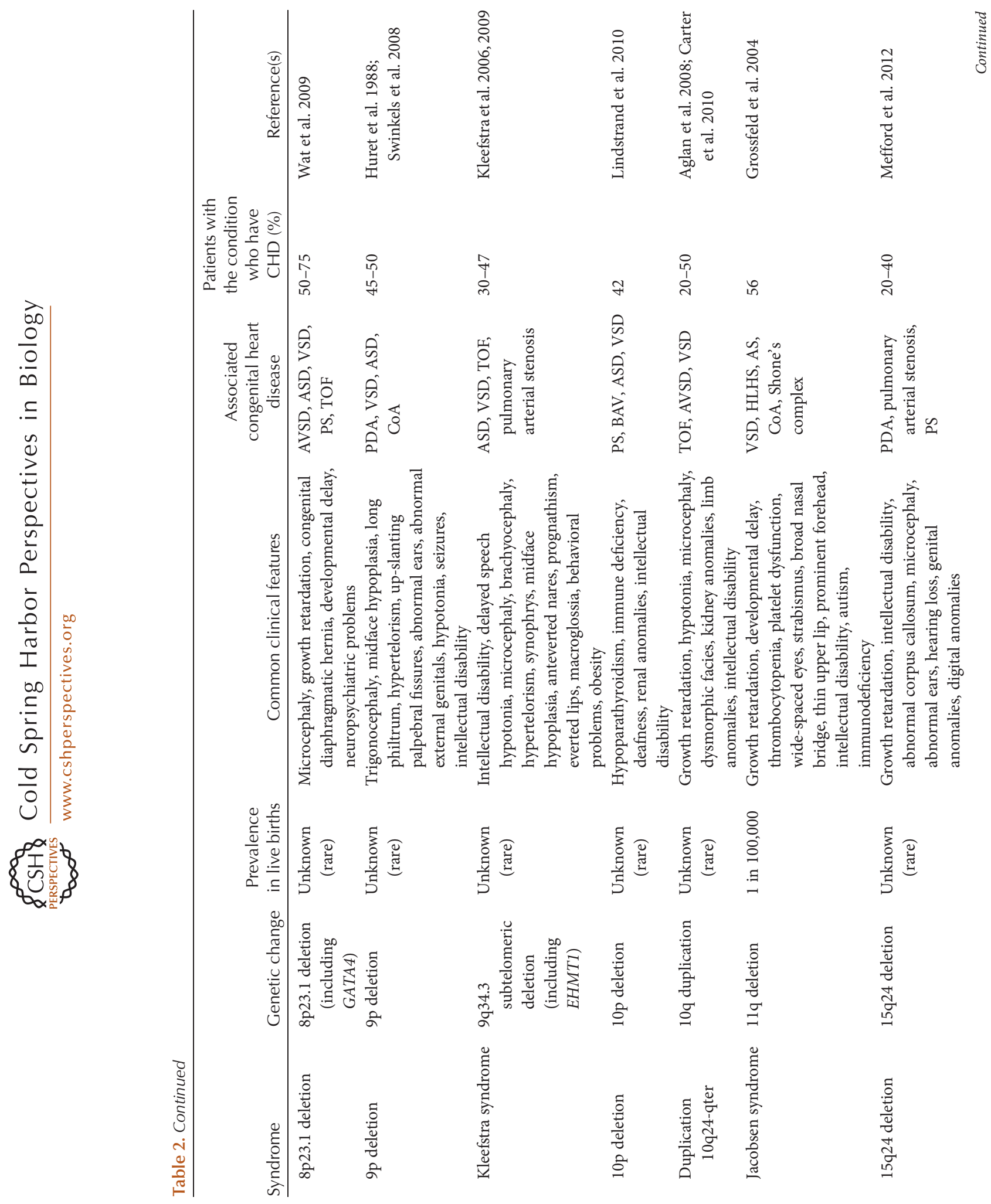
S.N. Nees and W.K. Chung
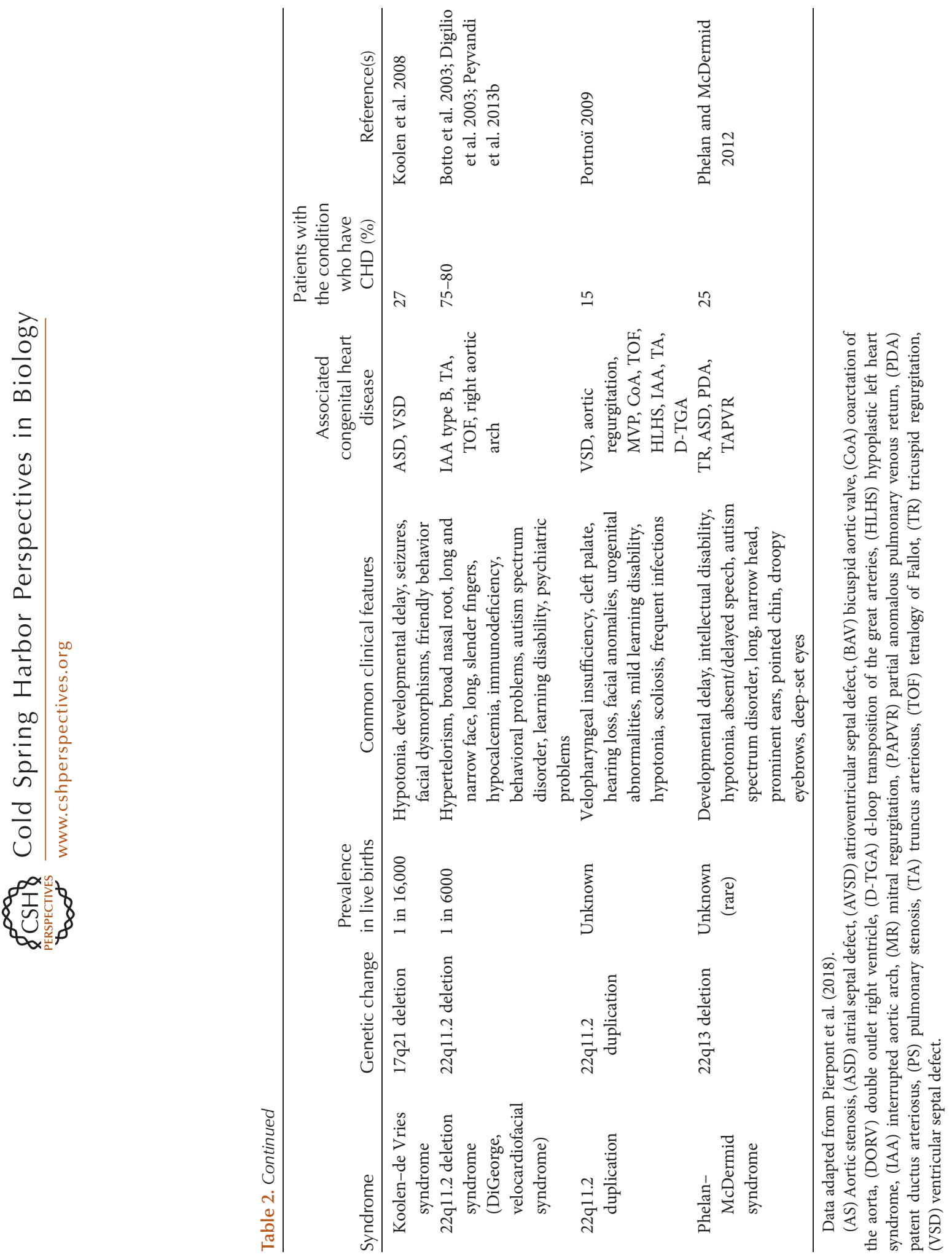
tients with trisomy 18 have CHD with PDA and VSD being the most common diagnoses. Most patients show polyvalvar dysplasia with two or more valves showing thickened, myxomatous, or dysplastic leaflets, although regurgitation and stenosis are uncommon (Van Praagh et al. 1989; Musewe et al. 1990). The majority of trisomy 13 patients have cardiac defects with PDA, ASD, and VSD being the most common lesions (Musewe et al. 1990; Lin et al. 2007). Life expectancy is limited in both trisomy 18 and 13, and most individuals die within the first year of life. Therefore, there has been significant debate as to whether repair of $\mathrm{CHD}$ should be offered in these patients (Embleton et al. 1996; Rasmussen et al. 2003; Yates et al. 2011).

\section{Turner Syndrome}

Turner syndrome is a sex chromosome disorder that results from a complete or partial loss of an $\mathrm{X}$ chromosome resulting in $45, \mathrm{X}$ karyotype. Those with mosaicism or structural abnormalities of the $\mathrm{X}$ chromosome tend to have less severe phenotypes compared with those with complete loss (Gøtzsche et al. 1994; Bucerzan et al. 2017). The most common cardiac lesions associated with Turner syndrome are left-sided lesions including BAV in $30 \%$ of patients and coarctation of the aorta $(\mathrm{CoA})$ in $10 \%$ of patients. More serious lesions such as partial anomalous pulmonary venous return (PAPVR) and HLHS are less common (Mazzanti and Cacciari 1998; Sybert and McCauley 2004). Individuals with Turner syndrome can have hypertension in the absence of CHD and can develop aortic root dilation; it is therefore recommended that all patients have a baseline echocardiogram and be followed with serial imaging (Lacro et al. 1988; Gravholt et al. 2017).

\section{COPY NUMBER VARIATION}

CNVs consist of deletions or duplications of contiguous regions of DNA that affect $\sim 12 \%$ of the genome and can impact either a single gene or multiple contiguous genes (Redon et al. 2006). Pathogenic CNVs tend to be de novo and large and disrupt coding portions of genes. These are found more frequently in patients with CHD compared with controls. There is wide variation in the reported prevalence of CNVs between $3 \%$ and $25 \%$ depending on the method of detection. CNVs are observed more frequently in patients with CHD and extracardiac features compared with those with isolated CHD (Goldmuntz et al. 2011; Soemedi et al. 2012; Southard et al. 2012; Zhu et al. 2016). Thienpont et al. (2007) used array-comparative genomic hybridization $(\mathrm{CGH})$ in patients with $\mathrm{CHD}$ and associated extracardiac anomalies and identified likely pathogenic CNVs in $17 \%$ of patients. Glessner et al. (2014) performed WES in 538 patients with CHD and found that $9.8 \%$ of patients without a previous genetic diagnosis had a rare de novo CNV.

Recent data have shown that CNVs are not only causative of $\mathrm{CHD}$, but they also impact clinical outcomes. Carey et al. (2013) compared neurocognitive and growth outcomes in patients with single ventricle physiology and found that patients with pathogenic CNVs had decreased linear growth and those with CNVs associated with known genomic disorders had the poorest neurocognitive and growth outcomes. Kim et al. (2016) examined CNVs in 422 cases of nonsyndromic CHD and found that the presence of a likely pathogenic CNV was associated with a significantly lower transplant-free survival after surgery. The increased risk of morbidity in patients with large CNVs may be due to additional genes that are impacted or due to pleiotropic effects of single genes within the region. Some of the most common syndromes caused by CNVs and associated with CHD are described in this section. Additional details are included in Table 2.

\section{2q11.2 Deletion Syndrome}

$22 \mathrm{q} 11.2$ deletion syndrome is the most common microdeletion syndrome associated with CHD. The majority of patients clinically diagnosed with DiGeorge or velocardiofacial syndrome have a microdeletion of 22q11.2. Seventy-five to eighty percent of patients with 22 q11.2 deletion have CHD, with conotruncal defects being the most common lesions (Marino et al. 2001). 
The prevalence of 22q11.2 deletion in patients with $\mathrm{CHD}$ is highest in patients with type $\mathrm{B}$ interrupted aortic arch (IAA), truncus arteriosus, TOF, and isolated aortic arch anomalies (Nielsen and Wohlert 1991; McElhinney et al. 2001; Agergaard et al. 2012; Peyvandi et al. 2013a; Donofrio et al. 2014). Among patients with conotruncal lesions, up to $50 \%$ have a 22q11 deletion (Goldmuntz et al. 1998).

22 q11.2 deletion is a syndrome that involves a contiguous deletion, most commonly involving more than 40 genes. Efforts to determine which gene within this region is responsible for the cardiovascular phenotype initially focused on TBX1 (Jerome and Papaioannou 2001; Merscher et al. 2001). Mutations in TBX1 have been identified in patients with clinical features of DiGeorge syndrome without a deletion, supporting the role of TBX1 in the development of CHD (Yagi et al. 2003). There are some shared clinical features between 22q11.2 duplication syndrome and the deletion syndrome, and experimental evidence suggests that both overexpression and underexpression of $T B X 1$ in the developing outflow tract can lead to $\mathrm{CHD}$ (Chen et al. 2014; Hasten et al. 2018). Some individuals with conotruncal defects and features of DiGeorge syndrome have a deletion in $22 \mathrm{q} 11$ that does not encompass the TBX1 gene, and two other genes in this region, CRKL and MAPK1, have been associated with the CHD phenotype (Breckpot et al. 2012; Thorsson et al. 2015).

\section{Williams-Beuren Syndrome}

Williams-Beuren syndrome, or Williams syndrome, is caused by a contiguous gene deletion at 7q11.23 that encompasses the elastin gene ELN (Ewart et al. 1993; Morris and Mervis 2002). Similar to 22q11 deletion syndrome, deletions are often sporadic but can be inherited. Between $50 \%$ and $80 \%$ of patients with Williams syndrome have CHD, most commonly supravalvar aortic stenosis (AS), supravalvar pulmonary stenosis (PS), and branch pulmonary artery stenosis (Kececioglu et al. 1993). Whereas the supravalvar AS tends to progress in childhood, the PS can improve (Wren et al. 1990; Eronen et al. 2002). Patients with Williams syndrome are at increased risk of sudden cardiac death and anesthesia-related complications (Conway et al. 1990; Latham et al. 2016). These complications are thought to arise from abnormalities in the coronary arteries and ventricular hypertrophy secondary to outflow obstruction, but the precise mechanisms are not known.

Mutations in ELN, a critical component of vascular tissue, are observed in patients with autosomal dominant isolated supravalvar AS, leading to the conclusion that haploinsufficiency of this gene is the etiology of CHD in patients with Williams syndrome (Curran et al. 1993; Ewart et al. 1993; Li et al. 1997a). Mutations in ELN lead to a vasculopathy that can cause arterial narrowing with thickened arterial walls. Narrowing of the aorta, coronary arteries, and renal arteries often lead to complications in these patients. It is recommended that all patients with supravalvar AS and patients with peripheral PS that does not resolve in the first few years of life undergo genetic testing (Pierpont et al. 2018).

\section{SINGLE-GENE DEFECTS}

In addition to CNVs, de novo sequence variants in single genes have been identified using WES in patients with $\mathrm{CHD}$, both in syndromic and nonsyndromic cases. Patients with $\mathrm{CHD}$ have an excess burden of de novo protein altering variants in genes that are expressed during cardiac development (Zaidi et al. 2013). A European study using WES in 1891 patients found that in patients with nonisolated CHD, there were an increased number of de novo protein-truncating variants and deleterious missense variants in known autosomal dominant CHD-associated genes as well as in non-CHD genes associated with developmental delay. In isolated $\mathrm{CHD}$ patients, there was a much lower frequency of de novo deleterious variants, but there was an increase in rare, inherited protein-truncating variants in CHD-associated genes likely representing mutations that are incompletely penetrant (Sifrim et al. 2016).

If there is family history of a syndrome that involves $\mathrm{CHD}$, testing for single-gene defects can be targeted based on family member test 
results or clinical suspicion. With the exception of Noonan syndrome panels, gene panels have not been routinely incorporated into testing for CHD because of the large number of genes involved. Therefore, in patients with a strong suspicion for a genetic cause of CHD, WES can be used effectively to identify single-gene defects.

\section{Monogenic Conditions Causing Syndromic CHD}

As sequencing techniques have improved, the genetic causes of several well-characterized clinical syndromes have been discovered. The following section describes examples of the most common monogenic syndromes associated with CHD. These syndromes are inherited in an autosomal dominant manner. Some are caused by variants in one gene and others are genetically heterogeneous. Table 3 contains additional details for selected syndromes.

\section{Alagille Syndrome}

Alagille syndrome is a condition consisting of $\mathrm{CHD}$, hepatic complications including bile duct paucity and cholestasis, and skeletal and ophthalmologic anomalies. There is significant variability in the expression even within the same family, with some individuals displaying very mild features and others with severe CHD or liver disease leading to transplant or death (Quiros-Tejeira et al. 1999; Kamath et al. 2003; Izumi et al. 2016; Ziesenitz et al. 2016). More than $90 \%$ of patients with Alagille syndrome have cardiovascular involvement. The most common lesion is branch pulmonary artery stenosis. More complex lesions include TOF with or without pulmonary atresia (Emerick et al. 1999; McElhinney et al. 2002). Other vascular anomalies are frequently found in patients with Alagille syndrome and are a significant cause of mortality (Kamath et al. 2004).

Alagille syndrome is genetically heterogeneous; the two most commonly associated genes are JAG1, which encodes a ligand in the Notch signaling pathway, and NOTCH2, a Notch receptor (Li et al. 1997b; Oda et al. 1997; McDaniell et al. 2006; Kamath et al. 2012). The Notch signaling pathway is important for controlling cell fate during development, and mutations in this pathway are also associated with other cardiac diseases (Niessen and Karsan 2008). JAG1 mutations are found in $\sim 90 \%$ of individuals with clinical Alagille syndrome, and these are usually loss-of-function mutations, suggesting haploinsufficiency as the mechanism (Warthen et al. 2006). In addition, $3 \%-7 \%$ of patients have deletions of chromosome 20p12, which contains JAG1. In a large family with cardiac defects typical of Alagille syndrome but no hepatic phenotype, a missense mutation that leads to slightly decreased JAG1 was identified suggesting that the variable expression may be associated with the amount of JAG1 (Lu et al. 2003). NOTCH2 mutations are found in $1 \%-2 \%$ of individuals with Alagille syndrome (Spinner et al. 1993; McDaniell et al. 2006).

\section{Holt-Oram Syndrome}

The two most common features of Holt-Oram syndrome are CHD and upper extremity malformations (Holt and Oram 1960). All patients with Holt-Oram syndrome have some upper limb anomaly ranging from mild abnormalities of the carpal bone to complete phocomelia (McDermott et al. 1993). Among patients with Holt-Oram syndrome, 75\% have CHD, and the most common types are ASDs and VSDs. More complex forms of CHD occur in $~ 15 \%-25 \%$ of patients (Sletten and Pierpont 1996; Baban et al. 2014; Barisic et al.2014). Patients are also at risk for cardiac conduction disease, which can be progressive and lead to complete heart block (McDermott et al. 1993; Basson et al. 1994).

About $75 \%$ of cases of Holt-Oram syndrome are caused by mutations in TBX5, a member of the T-box family of transcription factors, which plays a role in regulation of gene expression during embryogenesis (Basson et al. 1997; Li et al. 1997c; McDermott et al. 2005). TBX5 is expressed in the developing heart and limb and has been shown to be involved in the development of the cardiac septum and conduction system, consistent with the clinical findings in Holt-Oram syndrome (Steimle and Moskowitz 2017). Most of the variants in TBX5 are 
S.N. Nees and W.K. Chung
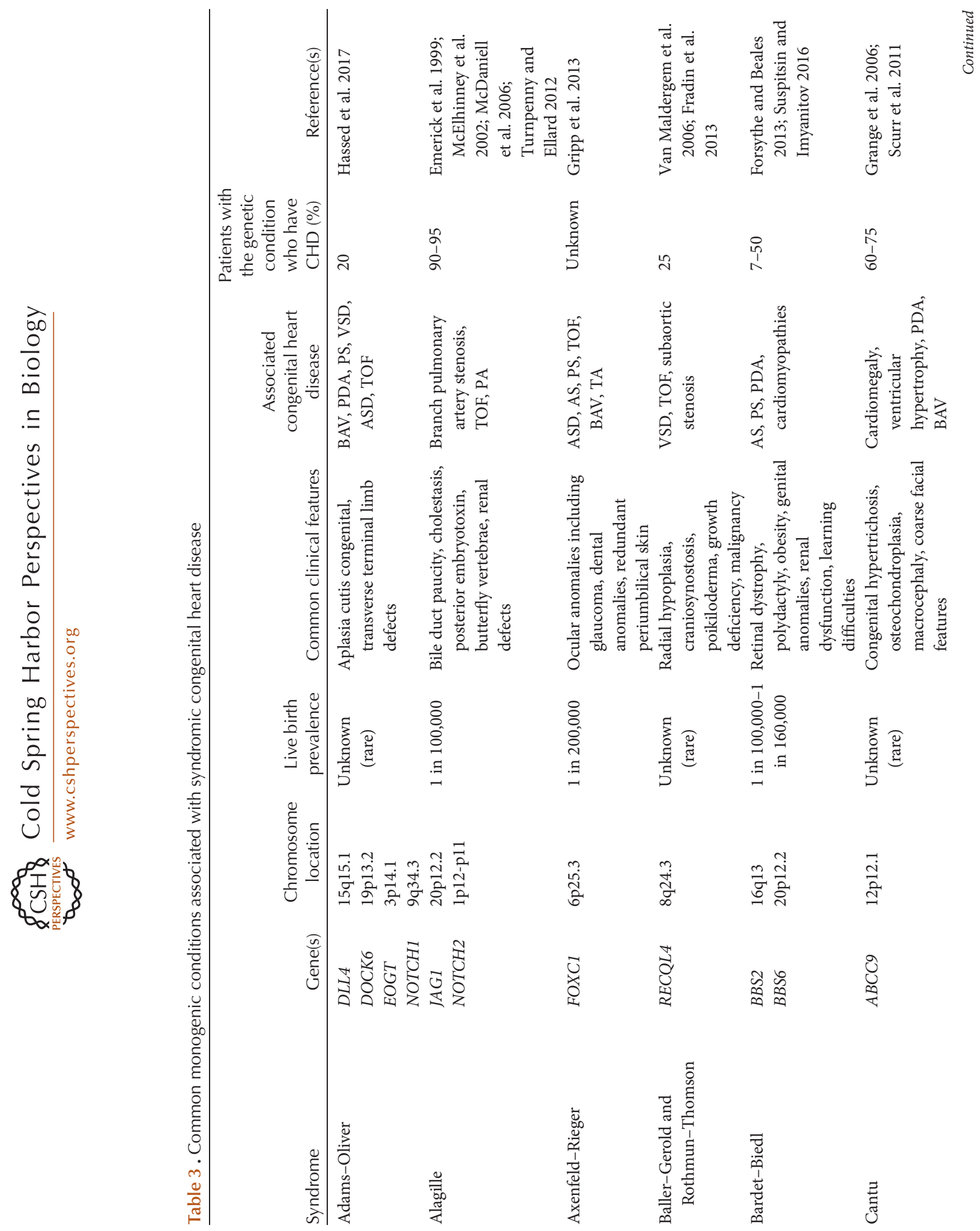
Genetic Basis of Human CHD
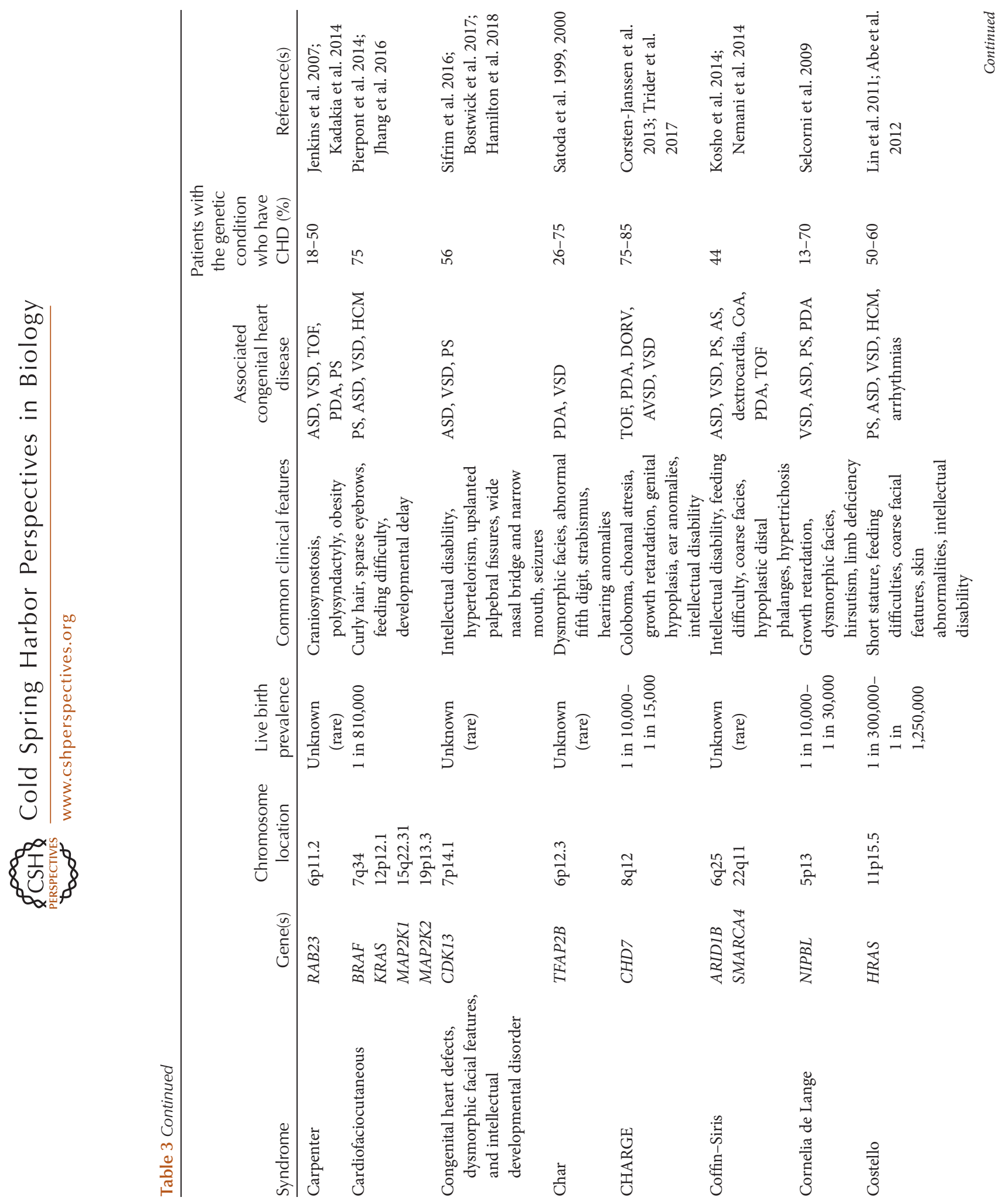
S.N. Nees and W.K. Chung
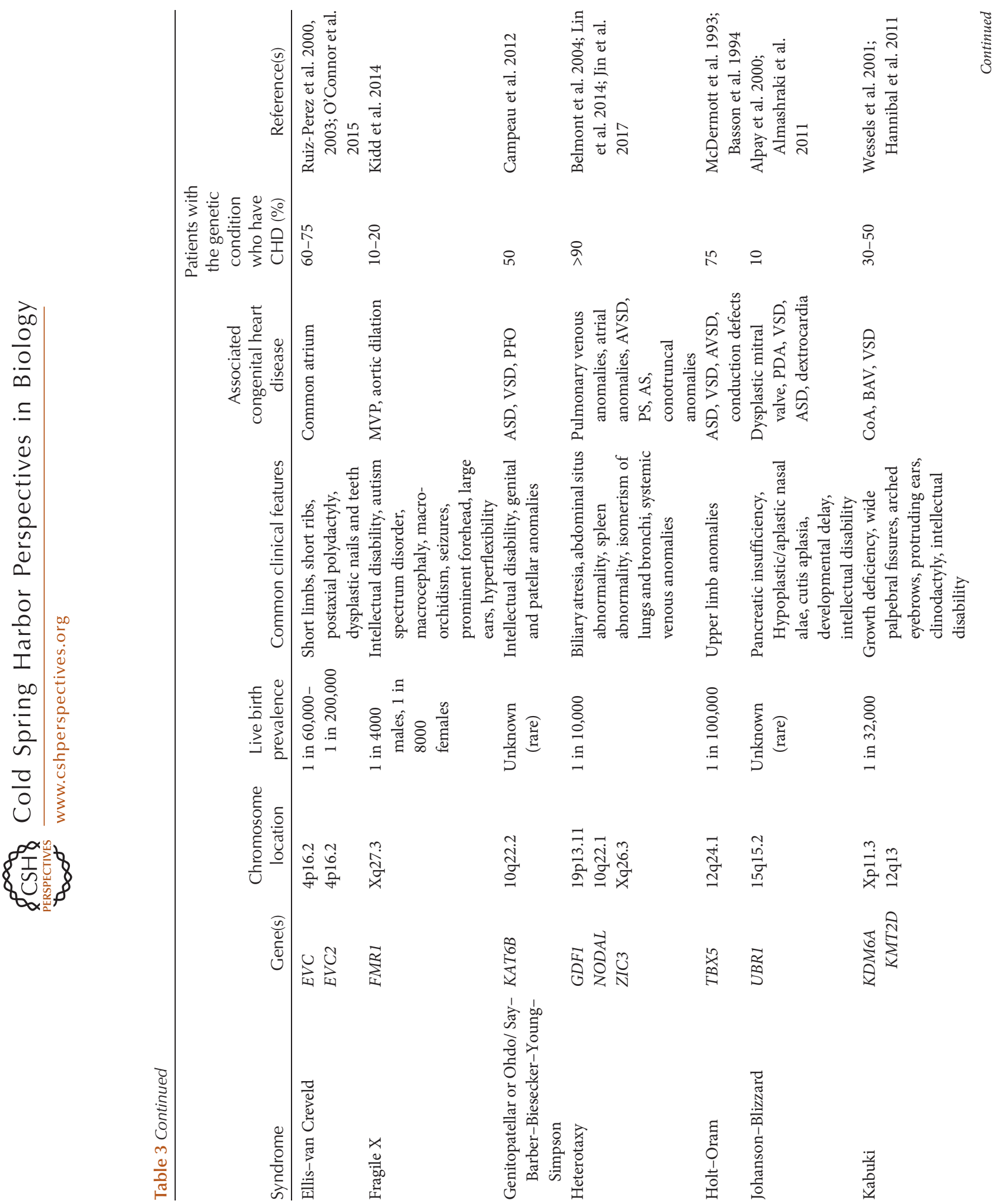
Genetic Basis of Human CHD
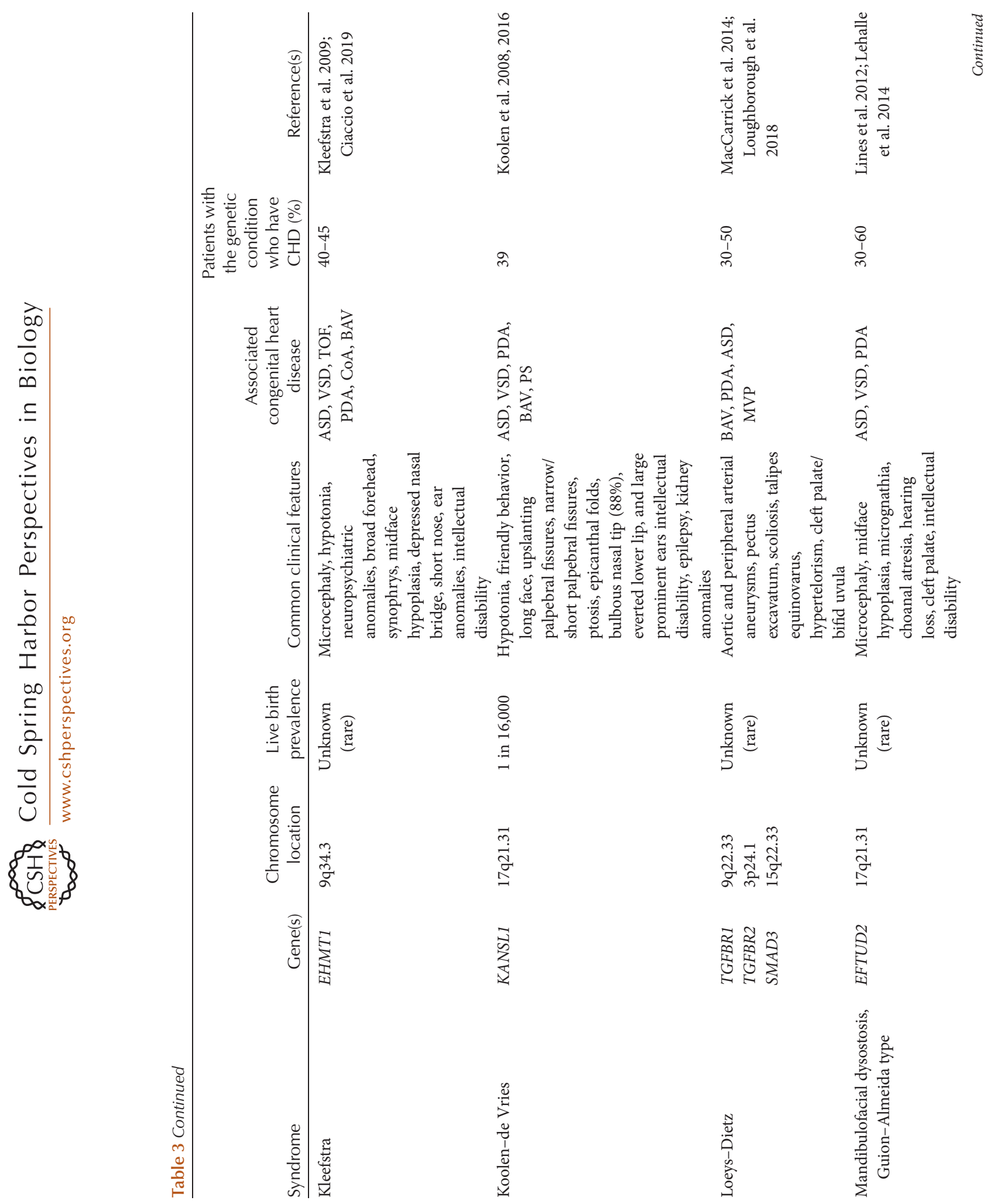
S.N. Nees and W.K. Chung
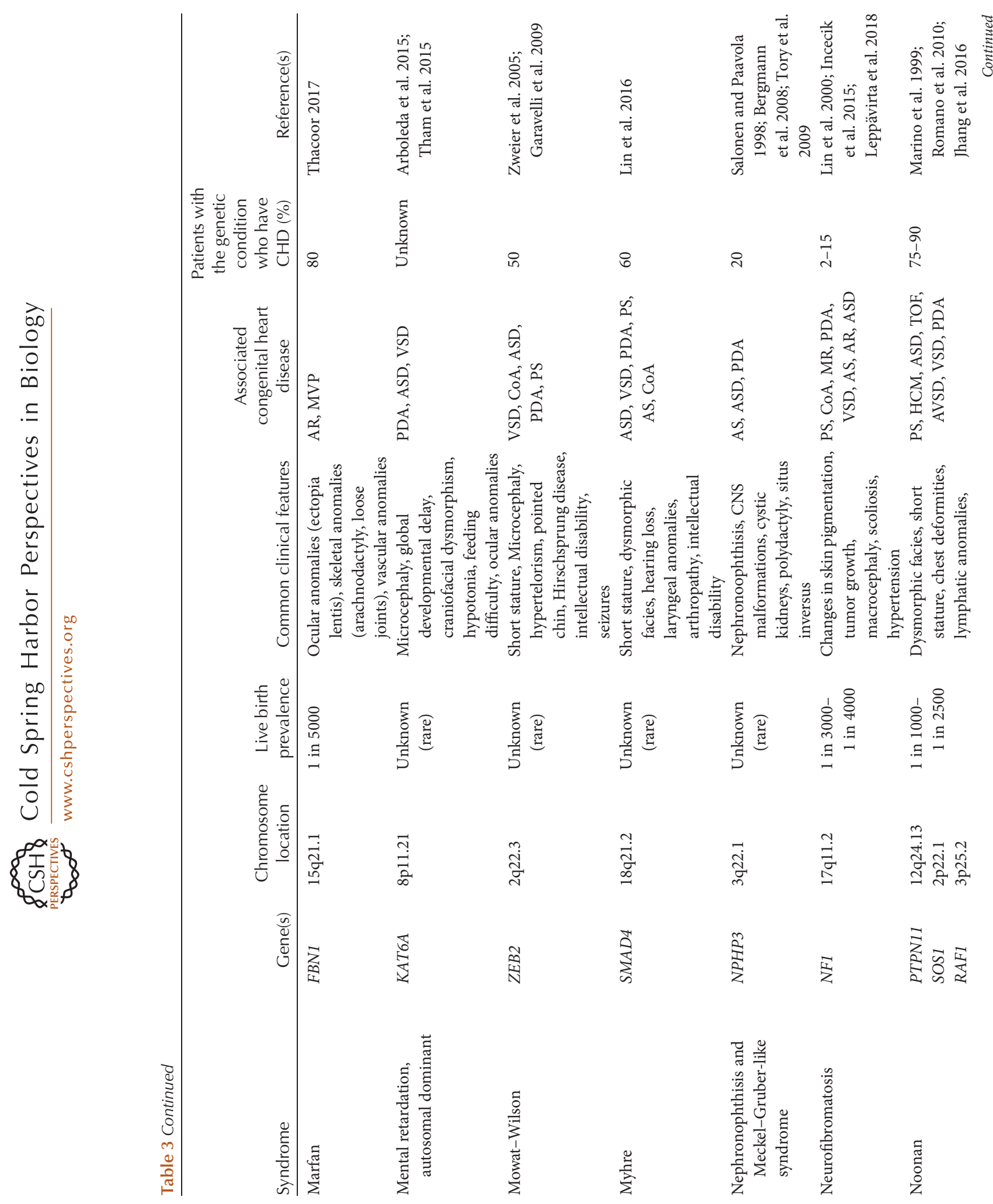
Genetic Basis of Human CHD
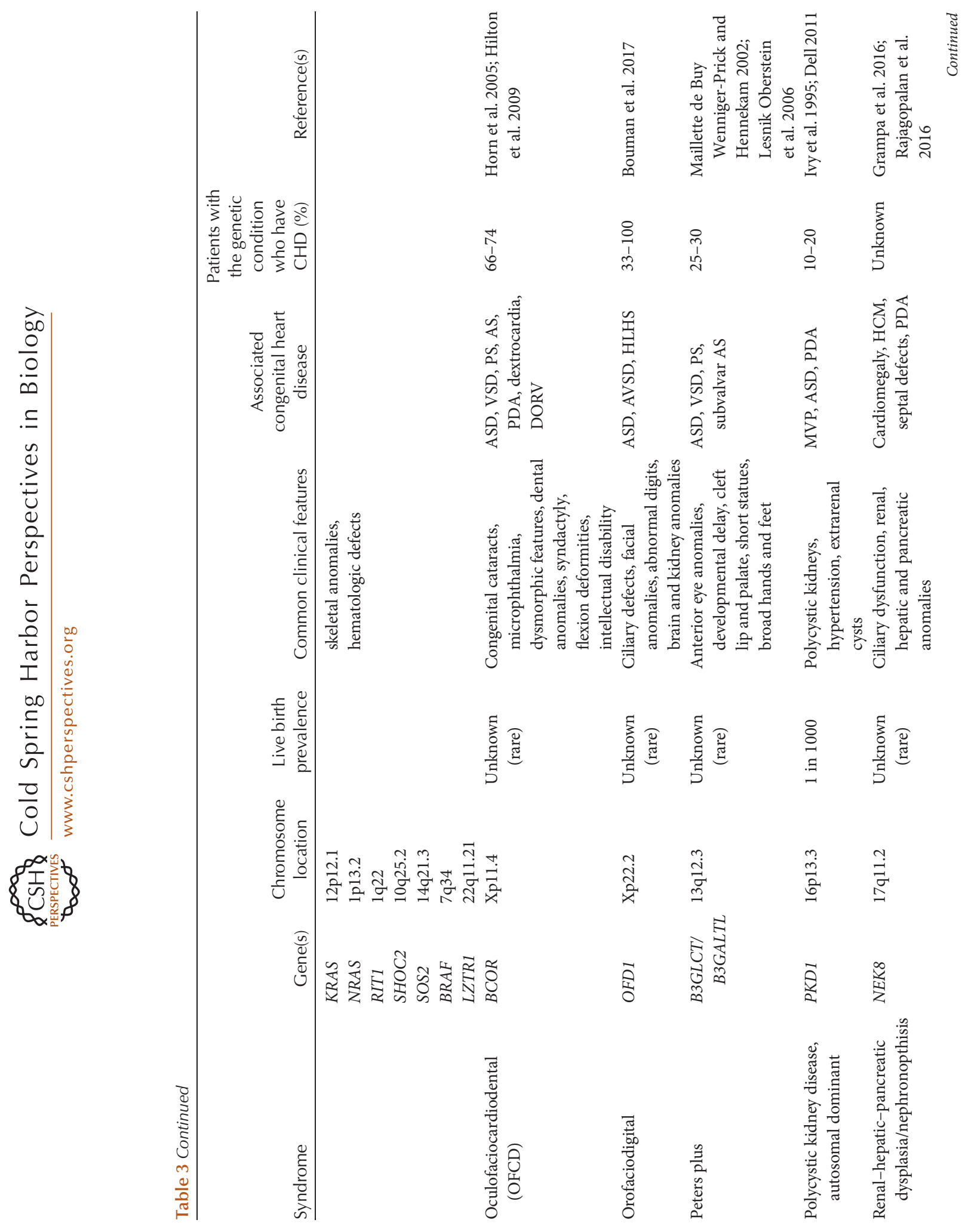
S.N. Nees and W.K. Chung
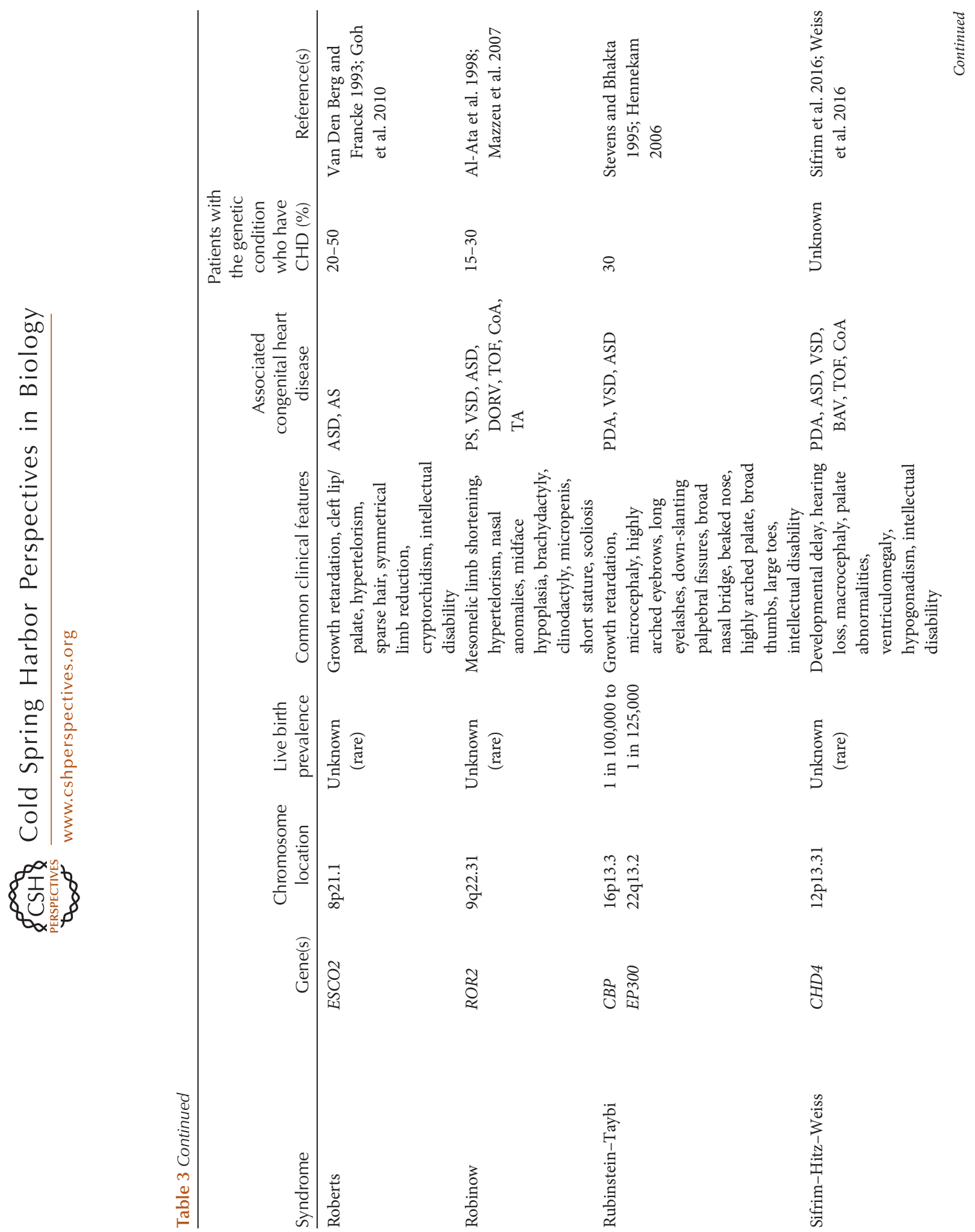
Genetic Basis of Human CHD
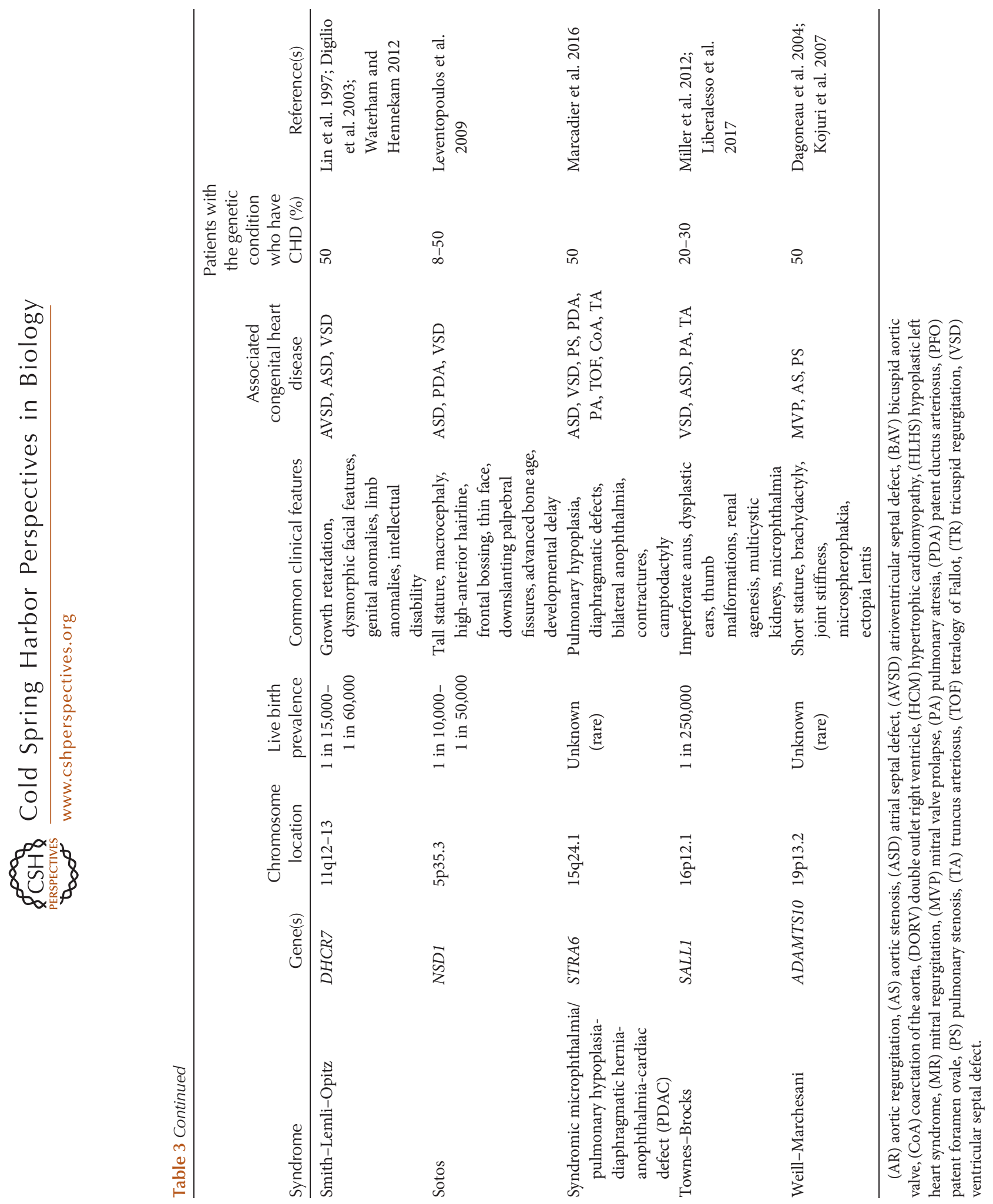
S.N. Nees and W.K. Chung

truncating variants, and the mechanism of disease is suspected to be haploinsufficiency. However, some variants that cause gain of function have similar phenotypes (Basson et al. 1997, 1999; Fan et al. 2003; Böhm et al. 2008; Muru et al. 2011). In the remaining $25 \%$ of cases of Holt-Oram syndrome, no genetic etiology has been identified, although it is hypothesized that these patients may have mutations in regulatory domains of TBX5 not included in routine sequencing.

\section{Noonan Syndrome and RASopathies}

Noonan syndrome and the RASopathies are a group of disorders with overlapping phenotypes including $\mathrm{CHD}$, short stature, dysmorphic facial features, and abnormal neurodevelopment. These disorders are caused by mutations in genes that encode proteins involved in the RAS/MAPK pathway, a signal-transduction pathway important for cell growth, differentiation, senescence, and death (Allanson 2016). Other than Noonan syndrome, disorders include cardiofaciocutaneous syndrome (CFC), Costello syndrome (CS), and Noonan syndrome with multiple lentigines.

Noonan syndrome is a disorder with both clinical and genetic heterogeneity consisting of characteristic facial features, short stature, CHD, cardiomyopathy, and chest deformities (Romano et al. 2010; Allanson and Roberts 2016). Cardiac involvement is present in $80 \%-90 \%$ of individuals. The most common cardiovascular findings are PS in 50\%-60\% and hypertrophic cardiomyopathy (HCM) in 20\% (Marino et al. 1999; El Bouchikhi et al. 2016; Jhang et al. 2016). The presence of HCM contributes to significant mortality and tends to be earlier-onset and more rapidly progressive than other types of pediatric HCM (Wilkinson et al. 2012; Gelb et al. 2015).

About one-half of the patients with Noonan syndrome have missense variants in PTPN11, which lead to activation of SHP2 and increased RAS/MAPK signaling (Tartaglia et al. 2001, 2002). Among those without PTPN11 variants, $20 \%$ have variants in SOS1 (Roberts et al. 2007). The cardiovascular manifestations of Noonan syndrome vary depending on the mutation. $\mathrm{Mu}$ tations in PTPN11 are more commonly associ- ated with PS, whereas mutations in RAF1 or RIT1 are associated with a high risk of HCM (Tartaglia et al. 2002; Aoki et al. 2016; Jhang et al. 2016; Kouz et al. 2016).

The other RASopathies share some common features, including developmental delays, short stature, ptosis, hypertelorism, and macrocephaly. Individuals with CFC and CS tend to have more severe cognitive impairment compared with individuals with Noonan syndrome (Abe et al. 2012). Cardiac defects are found in $\sim 75 \%$ of individuals with CFC, and, similar to Noonan syndrome, the most common findings are PS and HCM (Pierpont et al. 2014; Jhang et al. 2016). HCM is found in the majority of individuals with Noonan syndrome with multiple lentigines and is much more frequent than in individuals with Noonan syndrome (Limongelli et al. 2007; Aoki et al. 2016).

Given the clinical and genetic overlap between the RASopathies, gene panels have been developed that allow for sequencing the most commonly affected genes. These are useful in evaluation of patients with CHD in whom a RASopathy is suspected, because it may be difficult to distinguish between the syndromes based on clinical features alone, especially in infancy. An accurate diagnosis can assist with screening for other systemic involvement and providing prognostic information.

The majority of mutations causing RASopathies are gain-of-function mutations leading to increased signaling in the Ras/MAPK pathway (Carta et al. 2006; Pandit et al. 2007; Roberts et al. 2007, 2013; Cordeddu et al. 2009; Martinelli et al. 2010; Tartaglia et al. 2011; El Bouchikhi et al. 2016; Kouz et al. 2016). This provides a potential therapeutic target for inhibitors of RAS/MAPK signaling cascade (Chen et al. 2010; Marin et al. 2011; Rauen et al. 2011; $\mathrm{Wu}$ et al. 2011; Inoue et al. 2014). In one case report, a rapamycin analog was used to inhibit mTOR activity as palliative therapy in an individual with Noonan syndrome with multiple lentigines (NSML) and severe HCM, but further research is needed to determine if these therapies can improve the neurodevelopmental or cardiovascular outcomes in patients with these disorders (Hahn et al. 2015; Aoki et al. 2016). 


\section{Heterotaxy and Ciliopathies}

The heart is an asymmetric organ, and left-right patterning is critical for normal cardiac development. Disorders of left-right patterning include heterotaxy syndrome (HTX), in which there is abnormal sidedness of multiple organs, and situs inversus totalis (SIT), in which the organs are in a mirror-image pattern. Data from the National Birth Defects Prevention study showed that among patients with laterality defects, $68 \%$ had complex CHD and another $9 \%$ had simple CHD. Those with HTX were much more likely to have complex CHD compared with those with SIT (Lin et al. 2014). The association between CHD and laterality defects suggests a common developmental mechanism, perhaps because of defects in cilia as the primary cause of these abnormalities.

Cilia are organelles that have a crucial role in cellular signaling during development, particularly in the proper formation of the left-right axis in the developing embryo (Yoshiba and Hamada 2014). Abnormal ciliary structure or function is associated with syndromic ciliopathies, which include primary ciliary dyskinesia (PCD) and HTX, both of which are associated with CHD (Sutherland and Ware 2009).

A study examining chemically mutagenized fetal mice identified more than 200 mouse lines with various forms of $\mathrm{CHD}, 30 \%$ of which were consistent with HTX. WES in the fetal mice identified recessive CHD mutations in 61 genes, more than one-half of which were cilia-related (Li et al. 2015). In a study of WES in a large cohort of individuals with CHD, among 28 de novo mutations, 13 were in genes that were also identified in the mouse screen (Zaidi et al. 2013; Klena et al. 2017).

HTX is associated with CHD in the majority of individuals. Individuals with HTX are classified into two categories: left atrial isomerism (polysplenia syndrome) and right atrial isomerism (asplenia syndrome). In left atrial isomerism, common types of CHD include interruption of the inferior vena cava, PAPVR, and heart block. In right atrial isomerism, the most common defects are AVSDs, total anomalous pulmonary venous return (TAPVR), and cono- truncal defects. Extracardiac manifestations include spleen abnormalities, gut malrotation, biliary atresia, and CNS abnormalities (Sutherland and Ware 2009; Lin et al. 2014). HTX has a high risk of familial recurrence (Oyen et al. 2010). All types of inheritance including Xlinked, autosomal dominant, and autosomal recessive have been described with multiple implicated genes including LEFTYA, CRYPTIC, and $A C V R 2 B$ (Belmont et al. 2004). Pathogenic variants in ZIC3, a zinc-finger transcription factor involved in heart looping, are thought to contribute to $\sim 5 \%$ of HTX cases in males (Cowan et al. 2014; Paulussen et al. 2016).

PCD is a disorder characterized by abnormal ciliary motility in the airway tract that leads to frequent respiratory infections and complications (Mirra et al. 2017; Dalrymple and Kenia 2018). HTX and associated CHDs are found in $\sim 6 \%$ of patients with PCD showing the overlapping phenotypes and genetic etiologies of these conditions (Kennedy et al. 2007).

There is evidence that mutations in cilia genes are also involved in isolated CHD-especially AVSDs and D-transposition of the great arteries (D-TGA) (Versacci et al. 2018). In patients with CHD but no HTX, there is a high incidence of ciliary motion defects-up to $51 \%$ in one study (Garrod et al. 2014).

Given the significant genetic heterogeneity seen in HTX and PCD, genetic testing can be difficult. All patients should have CMA first because some CNVs and chromosomal abnormalities can be associated with HTX (Cowan et al. 2016). Gene panels are available for PCD, which include the most commonly associated genes (Pierpont et al. 2018).

\section{GDF1 and Founder Ashkenazi Mutation}

Given the heterogeneity of $\mathrm{CHD}$, there are likely to be genes involved in the pathogenesis of $\mathrm{CHD}$ in specific populations. One such gene is GDF1, which is associated with CHD in the Ashkenazi Jewish population. A study screening 375 unrelated patients with CHD identified loss-of-function mutations in GDF1 among cases with various types of $\mathrm{CHD}$ including conotruncal defects and atrioventricular canal defects. These 
were heterozygous mutations, and they hypothesized that GDF1 represented a susceptibility gene (Karkera et al. 2007). Linkage analysis in a family with right atrial isomerism led to the identification of compound heterozygous recessively inherited truncating mutations in GDF1 (Kaasinen et al. 2010). A large study using WES data for $2871 \mathrm{CHD}$ cases showed an increase in homozygous mutations in GDF1 among cases with evidence of Ashkenazim based on PCA analysis. One specific mutation, c.1091T $>$ C, accounted for $\sim 5 \%$ of severe CHD cases among those with Ashkenazi descent (Jin et al. 2017). Although the overall contribution to CHD is likely low, $G D F 1$ is an important contributor in certain populations (Sun et al. 2013).

\section{Monogenic Causes of Isolated CHD}

In addition to the syndromes described above, variants in an increasing number of genes have been identified in individuals with isolated CHD, initially through studies of familial CHD and later through the use of NGS. Among the genes that have been identified, most fall into one of the following functional categories and play an important role in normal cardiac development: transcription factors, signaling molecules, and structural proteins (Fahed et al. 2013). Select examples in each of these functional categories are described below. Table 4 contains additional genes associated with isolated $\mathrm{CHD}$. The list of genes associated with isolated $\mathrm{CHD}$ is rapidly expanding but it is often difficult to prove the pathogenicity of rare variants, especially in the setting of phenotypic heterogeneity.

\section{Transcription Factors}

There is a set of highly conserved transcription factors that are critical for cardiac development (Olson 2006; Kodo et al. 2012). Mutations in the homeobox transcription factor NKX2-5 were reported in both familial and sporadic cases of $\mathrm{CHD}$ associated with conduction defects in 1998 (Schott et al. 1998). The most common phenotype in individuals with NKX2-5 mutations is ASD with conduction delay (Benson et al. 1999; Stallmeyer et al. 2010). Identification of NKX2-5 mutations in individuals with these cardiac findings is clinically relevant because they are at increased risk of progressive conduction disease and sudden cardiac death, and the genetic information is considered in decisionmaking regarding pacemakers and implantable cardiac defibrillators (Perera et al. 2014; Ellesøe et al. 2016).

Other transcription factors that have been associated with structural heart disease in both human and mouse models include members of the GATA family (Garg et al. 2003; Rajagopal et al. 2007; Kodo et al. 2009; Wei et al. 2013; Qian et al. 2017) and members of the Tbox family that have been implicated in both syndromic and isolated forms of CHD (Kirk et al. 2007; Griffin et al. 2010; Smemo et al. 2012; Huang et al. 2017). Recent work has identified SOX17 as a contributor to CHD associated with pulmonary hypertension as well as isolated and familial pulmonary hypertension (Zhu et al. 2018). SOX17 is a transcriptional target of GATA4, and it inhibits signaling in the WNT/B-catenin pathway involved in cardiac development (Zorn et al. 1999; Holtzinger et al. 2010).

\section{Cell Signaling and Adhesion Models}

Many signaling pathways are involved in cardiac development, and genes in these pathways are frequently disrupted in patients with CHD. Notch signaling is important for cellular differentiation and is involved in the pathogenesis of both isolated and syndromic CHD ( $\mathrm{Li}$ et al. 1997b; McDaniell et al. 2006; Kamath et al. 2012; Stittrich et al. 2014; Meester et al. 2019). Mutations in NOTCH1 have been identified in autosomal dominantly inherited CHD consisting primarily of BAV and are associated with abnormalities of the outflow tracts and semilunar valves (Garg et al. 2005; KerstjensFrederikse et al. 2016; Preuss et al. 2016). In patients with isolated TOF, NOTCH1 was noted to be the most frequent site of genetic variants accounting for $4.5 \%$ of patients (Page et al. 2019).

Another cell signaling family that is crucial for cardiac development is the TGF- $\beta$ cytokine superfamily. Several genes in this family are im- 
Table 4. Selected monogenic causes of isolated congenital heart disease

\begin{tabular}{|c|c|c|c|c|}
\hline Gene & $\begin{array}{l}\text { Chromosome } \\
\text { location }\end{array}$ & $\begin{array}{l}\text { Mode of } \\
\text { inheritance }\end{array}$ & Cardiac disease & Reference(s) \\
\hline ACTC1 & $15 q 14$ & $\mathrm{AD}$ & ASD, HCM, DCM, LVNC & Matsson et al. 2008 \\
\hline CITED2 & $6 \mathrm{q} 24.1$ & $\mathrm{AD}$ & ASD, VSD & Sperling et al. 2005 \\
\hline CRELD1 & $3 p 25.3$ & $\mathrm{AD}$ & ASD, AVSD & Guo et al. 2010 \\
\hline GATA4 & $8 \mathrm{p} 23.1$ & $\mathrm{AD}$ & ASD, VSD, AVSD, PS, TOF & Zhang et al. 2017 \\
\hline GATA5 & $20 \mathrm{q} 13.33$ & $\mathrm{AD}, \mathrm{AR}$ & ASD, BAV, TOF, VSD, DORV & Jiang et al. 2013; Shan et al. 2014 \\
\hline GATA6 & $18 \mathrm{q} 11.2$ & $\mathrm{AD}$ & TA, TOF & $\begin{array}{l}\text { Kodo et al. 2009; Xu et al. 2018; } \\
\text { Zhang et al. } 2018\end{array}$ \\
\hline HAND1 & $5 q 33.2$ & $\mathrm{AD}$ & SV, VSD & Reamon-Buettner et al. 2008, 2009 \\
\hline HAND2 & $4 \mathrm{q} 34.1$ & $\mathrm{AD}$ & PS, TOF, VSD & $\begin{array}{l}\text { Shen et al. 2010; Topf et al. 2014; Sun } \\
\text { et al. } 2016\end{array}$ \\
\hline MEIS2 & $15 q 14$ & $\mathrm{AD}$ & ASD, VSD, CoA & Verheije et al. 2019 \\
\hline МYBРC3 & $11 \mathrm{p} 11.2$ & $\mathrm{AD}$ & ASD, PDA, VSD, MR & Wells et al. 2011; Wessels et al. 2015 \\
\hline MYH6 & $14 \mathrm{q} 11.2$ & $\mathrm{AD}, \mathrm{AR}$ & ASD, HCM, DCM, HLHS & Theis et al. 2015; Jin et al. 2017 \\
\hline MYH7 & $14 \mathrm{q} 11.2$ & $\mathrm{AD}$ for $\mathrm{CM}$ & EA, LVNC, HCM, DCM & $\begin{array}{l}\text { Postma et al. 2011; Hanchard et al. } \\
2016\end{array}$ \\
\hline NODAL & $10 \mathrm{q} 22.1$ & $\mathrm{AD}$ & D-TGA, DORV, TOF, VSD & $\begin{array}{l}\text { Roessler et al. 2008; Mohapatra et al. } \\
2009\end{array}$ \\
\hline NOTCH1 & $9 \mathrm{q} 34.3$ & $\mathrm{AD}$ & ASD, VSD, CoA, HLHS, DORV & $\begin{array}{l}\text { Garg et al. 2005; Kerstjens-Frederikse } \\
\text { et al. } 2016\end{array}$ \\
\hline NKX2-5 & $5 q 35.1$ & $\mathrm{AD}$ & ASD, TOF, HLHS & $\begin{array}{l}\text { Schott et al. 1998; Benson et al. 1999; } \\
\text { Stallmeyer et al. } 2010\end{array}$ \\
\hline NR2F2 & $15 q 26.2$ & $\mathrm{AD}$ & $\begin{array}{l}\text { AVSD, AS, CoA, VSD, HLHS, } \\
\text { TOF, DORV }\end{array}$ & $\begin{array}{l}\text { Al Turki et al. 2014; Bashamboo et al. } \\
\text { 2018; Qiao et al. } 2018\end{array}$ \\
\hline SMAD2 & $18 \mathrm{q} 21.1$ & $\mathrm{AD}$ & HTX, DORV, ASD, VSD, PDA & $\begin{array}{l}\text { Zaidi et al. 2013: Granadillo et al. } \\
2018\end{array}$ \\
\hline SMAD6 & $15 q 22.31$ & $\mathrm{AD}$ & $\mathrm{BAV}, \mathrm{CoA}, \mathrm{AS}$ & Gillis et al. 2017 \\
\hline TAB2 & $6 \mathrm{q} 25.1$ & $\mathrm{AD}$ & $\mathrm{BAV}, \mathrm{AS}, \mathrm{TOF}$ & Thienpont et al. 2010 \\
\hline$T B X 1$ & $22 \mathrm{q} 11.2$ & $\mathrm{AD}$ & $\begin{array}{l}\text { Conotruncal defects, VSD, IAA, } \\
\text { ASD }\end{array}$ & Yagi et al. 2003 \\
\hline TBX5 & $12 \mathrm{q} 24.1$ & $\mathrm{AD}$ & $\begin{array}{l}\text { VSD, ASD, AVSD, conduction } \\
\text { defects }\end{array}$ & Basson et al. 1999 \\
\hline TBX20 & $7 \mathrm{p} 14.2$ & Unknown & ASD, VSD, MS, DCM & Kirk et al. 2007 \\
\hline
\end{tabular}

Genes in this table are associated with congenital heart disease based on criteria established by The Clinical Genome Resource Gene Curation Working Group (2018).

(AS) aortic stenosis, (ASD) atrial septal defect, (AVSD) atrioventricular septal defect, (BAV) bicuspid aortic valve, (CM) cardiomyopathy, (COA) coarctation of the aorta, (DCM) dilated cardiomyopathy, (DORV) double outlet right ventricle, (DTGA) d-loop transposition of the great arteries, (EA) Ebstein's anomaly of the tricuspid valve, (HCM) hypertrophic cardiomyopathy, (HLHS) hypoplastic left heart syndrome, (HTX) heterotaxy syndrome, (IAA) interrupted aortic arch, (LVNC) left ventricular noncompaction, (MR) mitral regurgitation, (PDA) patent ductus arteriosus, (PS) pulmonary stenosis, (SV) single ventricle, (TA) truncus arteriosus, (TOF) tetralogy of Fallot, (VSD) ventricular septal defect.

plicated in heart development including $B M P-2$, $B M P-4, T G F-\beta 2$, and TGF- $\beta 3$ (Nakajima et al. 2000; Armstrong and Bischoff 2004). The TGF- $\beta$ superfamily also includes Nodal, a secreted signaling ligand that has been implicated in laterality defects including HTX as well as isolated CHD (Roessler et al. 2008; Mohapatra et al. 2009). Isolated CHD lesions associated with NODAL mutations include D-TGA, double outlet right ventricle (DORV), TOF, and isolated VSDs. Overexpression of TGF- $\beta 1$ seems to play a role in the development of pulmonary hypertension in patients with $\mathrm{CHD}$, suggesting that alterations in this pathway may have pleo- 
S.N. Nees and W.K. Chung

tropic effects on the heart as well as the pulmonary vasculature (Gao et al. 2005; Yuan 2018).

\section{Structural Proteins}

Mutations in structural cardiac proteins also contribute to CHD in some patients. Mutations in cardiac sarcomere proteins are associated with cardiomyopathies and recently have been reported in some types of CHD. MYH6 encodes myosin heavy chain 6 , and dominant mutations have been associated with ASDs in addition to dilated cardiomyopathy (Granados-Riveron et al. 2010; Posch et al. 2011). Recently, recessive MYH6 missense mutations were identified in two patients with HLHS and decreased ventricular function, suggesting a role in the development of the normal ventricular myocardium (Theis et al. 2015). Mutations in MYH7, another sarcomeric protein, have been associated with Ebstein's anomaly of the tricuspid valve and left ventricular noncompaction (Postma et al. 2011). ACTC1 encodes a cardiac actin and mutations have been identified in familial cases of ASDs without cardiac dysfunction (Matsson et al. 2008).

\section{Histone Modifiers}

WES has identified several monogenic causes of isolated and nonisolated CHD. Zaidi et al. (2013) used WES in 362 severe cases of CHD and showed an excess of likely damaging de novo variants in genes expressed during cardiac development. This study showed significant enrichment of genes involved in the modification of histone 3 lysine $4(\mathrm{H} 34 \mathrm{~K})$. Methylated H34K is an important regulator of developmental genes. Other genes in this pathway, including MLL2, KDM6A, and CHD7, have been previously associated with CHD (Vissers et al. 2004; Lederer et al. 2012). Histone modifications are important regulators of gene expression. These data suggest that the $\mathrm{H} 34 \mathrm{~K}$ pathway is important for appropriate gene regulation during cardiac development and that other epigenetic mechanisms may play a role in the pathogenesis of CHD. In addition, this shows the utility of using WES to identify new genes and mechanisms in cases of CHD of unknown etiology.

\section{COMMON VARIANTS AND CHD}

Given that the majority of CHD cases do not yet have a known genetic cause, several investigators have hypothesized that common variants may play a role in the risk of CHD. Genome wide association studies (GWASs) have been used to identify common variants associated with specific types of CHD. A large study of CHD found a region on chromosome $4 \mathrm{p} 16$ that was associated with risk of ASD, and genotype at this locus accounted for $\sim 9 \%$ of the population-attributable risk (Cordell et al. 2013a). A GWAS in the Han Chinese population identified two loci, 1p12 and 4q13.1, associated with CHD. Another study in the Han Chinese using a compound heterozygous model identified four additional loci that explained $7.8 \%$ of the CHD variance in the population, suggesting that multiple modes of inheritance are contributing (Jiang et al. 2018). Several studies have examined specific groups of CHD including left-sided lesions and TOF and have identified susceptibility loci that account for a small proportion of the genetic variation in each case (Cordell et al. 2013b; Mitchell et al. 2015; Hanchard et al. 2016). Although common variants likely have a role in CHD susceptibility, these account for only a small proportion of the genetic risk, and large studies of individuals with similar CHD lesions are needed to identify additional susceptibility loci.

\section{RECOMMENDATIONS FOR CLINICAL GENETIC TESTING}

Recommendations for clinical genetic testing in $\mathrm{CHD}$ are evolving. Any individual with features suggestive of a recognizable chromosomal condition should undergo focused testing. Because many syndromic forms of CHD have variable presentations, patients with $\mathrm{CHD}$ with any extracardiac finding including dysmorphic features, growth deficiency, developmental delay, or another congenital anomaly should be offered genetic testing. If there is a family history of congenital anomalies or multiple miscarriag- 
es, genetic testing should also be offered (Pierpont et al. 2007, 2018). In neonates and young infants, it can be difficult to appreciate dysmorphic features, cognitive delays, and extracardiac anomalies. Testing should be considered for these patients if they have a type of CHD that is frequently associated with genetic syndromes including TOF, IAA, truncus arteriosus, and left-sided obstructive lesions, even in the absence of other features (Ito et al. 2017). For fetuses diagnosed with $\mathrm{CHD}$, there is a much higher chance of identifying genetic abnormalities, possibly because of high rates of intrauterine demise with certain conditions. For this reason, genetic testing and counseling should be offered in all cases of prenatally diagnosed CHD because a positive test may help identify additional anomalies and affect pregnancy management (Donofrio et al. 2014; Bensemlali et al. 2016; Lazier et al. 2016).

CMA is the appropriate first-line test for most individuals and has been shown to be cost-effective (Manning and Hudgins 2010; Geddes et al. 2017). In cases in which rapid results will have a clinical benefit, FISH for aneuploidy or 22q11.2 deletion can be considered. The limitation of CMA is that balanced chromosomal rearrangements cannot be detected, and if this is suspected, karyotype is needed. If CMA is negative and a genetic cause of CHD is strongly suspected, WES can be considered.

\section{CONCLUDING REMARKS}

Congenital heart disease is a broad phenotype that encompasses many different cardiac structures and many genetic variants. Among patients with $\mathrm{CHD}, 8 \%-12 \%$ have an aneuploidy or large chromosomal abnormality, and 3\%-5\% have a single-gene defect. The frequency of detection of CNVs in CHD patients varies widely between $3 \%$ and $25 \%$ with increased frequency among those with nonisolated CHD. Recent evidence suggests that heterozygous de novo predicted deleterious SNVs can be identified in $8 \%$ of CHD patients and inherited autosomal recessive SNVs in 2\% (Jin et al. 2017). A given syndrome or genetic variant can cause different types of CHD in different patients because of genetic modifiers. In addition, for each type of $\mathrm{CHD}$, there is a long list of possible genetic causes. As sequencing becomes more cost-effective, additional causes will certainly be identified, and we are just beginning to understand how genetics impact outcomes among patients with CHD.

\section{ACKNOWLEDGMENTS}

S.N. receives salary support through a Ruth L. Kirschstein National Research Service Award of the National Institutes of Health under award number 5T32HL007854-22. Funding was provided for W.K.C. through the National Heart, Lung, and Blood Institute (NHLBI) U01 HL098163 and R01 12008885.

\section{REFERENCES}

Abe Y, Aoki Y, Kuriyama S, Kawame H, Okamoto N, Kurosawa K, Ohashi H, Mizuno S, Ogata T, Kure S, et al. 2012. Prevalence and clinical features of Costello syndrome and cardio-facio-cutaneous syndrome in Japan: findings from a nationwide epidemiological survey. Am J Med Genet Part A 158A: 1083-1094. doi:10.1002/ajmg.a.35292

Agarwal HS, Wolfram KB, Saville BR, Donahue BS, Bichell DP. 2014. Postoperative complications and association with outcomes in pediatric cardiac surgery. J Thorac Cardiovasc Surg 148: 609-616.e1. doi:10.1016/j.jtcvs.2013.10 .031

Agergaard P, Olesen C, Østergaard JR, Christiansen M, Sørensen KM. 2012. The prevalence of chromosome 22q11.2 deletions in 2,478 children with cardiovascular malformations. A population-based study. Am J Med Genet Part A 158A: 498-508. doi:10.1002/ajmg.a.34250

Aglan MS, Kamel AK, Helmy NA. 2008. Partial trisomy of the distal part of 10q: a report of two Egyptian cases. Genet Couns 19: 199-209.

Ahrens-Nicklas RC, Khan S, Garbarini J, Woyciechowski S, D’Alessandro L, Zackai EH, Deardorff MA, Goldmuntz E. 2016. Utility of genetic evaluation in infants with congenital heart defects admitted to the cardiac intensive care unit. Am J Med Genet Part A 170: 3090-3097. doi:10 .1002/ajmg.a.37891

Allanson JE. 2016. Objective studies of the face of Noonan, cardio-facio-cutaneous, and Costello syndromes: a comparison of three disorders of the Ras/MAPK signaling pathway. Am J Med Genet Part A 170: 2570-2577. doi:10.1002/ajmg.a.37736

Allanson JE, Roberts AE. 2016. Noonan syndrome. In GeneReviews ${ }^{\circledast}$. University of Washington, Seattle.

Allen HD, Driscoll DD, Shaddy RE, Feltes TF. 2013. Moss and Adams' heart disease in infants, children, and adolescents: including the fetus and young adult, 8th ed. Wolters Kluwer, Philadelphia. 
Almashraki N, Abdulnabee MZ, Sukalo M, Alrajoudi A Sharafadeen I, Zenker M. 2011. Johanson-Blizzard syndrome. World J Gastroenterol 17: 4247-4250. doi:10 $.3748 /$ wjg.v17.i37.4247

Al-Ata J, Paquet M, Teebi AS. 1998. Congenital heart disease in Robinow syndrome. Am J Med Genet 77: 332-333. doi:10.1002/(SICI)1096-8628(19980526)77:4<332::AIDAJMG16>3.0.CO;2-J

Alpay F, Gü D, Lenk MK, Oğur G. 2000. Severe intrauterine growth retardation, aged facial appearance, and congenital heart disease in a newborn with Johanson-Blizzard syndrome. Pediatr Cardiol 21: 389-390. doi:10.1007/ s002460010089

Al Turki S, Manickaraj AK, Mercer CL, Gerety SS, Hitz MP, Lindsay S, D’Alessandro LCA, Swaminathan GJ, Bentham J, Arndt AK, et al. 2014. Rare variants in NR2F2 cause congenital heart defects in humans. Am J Hum Genet 94: 574-585. doi:10.1016/j.ajhg.2014.03.007

Anaclerio S, Di Ciommo V, Michielon G, Digilio MC, Formigari R, Picchio FM, Gargiulo G, Di Donato R, De Ioris MA, Marino B. 2004. Conotruncal heart defects: impact of genetic syndromes on immediate operative mortality. Ital Heart J 5: 624-628.

Aoki Y, Niihori T, Inoue S, Matsubara Y. 2016. Recent advances in RASopathies. J Hum Genet 61: 33-39. doi:10 .1038/jhg.2015.114

Arboleda VA, Lee H, Dorrani N, Zadeh N, Willis M, Macmurdo CF, Manning MA, Kwan A, Hudgins L, Barthelemy F, et al. 2015. De novo nonsense mutations in KAT6A, a lysine acetyl-transferase gene, cause a syndrome including microcephaly and global developmental delay. Am J Hum Genet 96: 498-506. doi:10.1016/j.ajhg.2015.01.017

Armstrong EJ, Bischoff J. 2004. Heart valve development. Circ Res 95: 459-470. doi:10.1161/01.RES.0000141146 .95728.da

Baban A, Pitto L, Pulignani S, Cresci M, Mariani L, Gambacciani C, Digilio MC, Pongiglione G, Albanese S. 2014 Holt-Oram syndrome with intermediate atrioventricular canal defect, and aortic coarctation: functional characterization of a de novo TBX5 mutation. Am J Med Genet Part A 164: 1419-1424. doi:10.1002/ajmg.a.36459

Baker K, Sanchez-de-Toledo J, Munoz R, Orr R, Kiray S, Shiderly D, Clemens M, Wearden P, Morell VO, Chrysostomou C. 2012. Critical congenital heart diseaseutility of routine screening for chromosomal and other extracardiac malformations. Congenit Heart Dis 7: 145150. doi:10.1111/j.1747-0803.2011.00585.x

Bamshad MJ, Ng SB, Bigham AW, Tabor HK, Emond MJ, Nickerson DA, Shendure J. 2011. Exome sequencing as a tool for Mendelian disease gene discovery. Nat Rev Genet 12: $745-755$. doi: $10.1038 / \operatorname{nrg} 303$

Barisic I, Boban L, Greenlees R, Garne E, Wellesley D, Calzolari E, Addor MC, Arriola L, Bergman JE, Braz P, et al 2014. Holt Oram syndrome: a registry-based study in Europe. Orphanet J Rare Dis 9: 156. doi:10.1186/ s13023-014-0156-y

Bashamboo A, Eozenou C, Jorgensen A, Bignon-Topalovic J, Siffroi JP, Hyon C, Tar A, Nagy P, Sólyom J, Halász Z, et al. 2018. Loss of function of the nuclear receptor NR2F2, encoding COUP-TF2, causes testis development and cardiac defects in 46, XX children. Am J Hum Genet 102: 487-493. doi:10.1016/j.ajhg.2018.01.021
Basson CT, Cowley GS, Solomon SD, Weissman B, Poznanski AK, Traill TA, Seidman JG, Seidman CE. 1994. The clinical and genetic spectrum of the Holt-Oram syndrome (heart-hand syndrome). N Engl J Med 330: 885891. doi:10.1056/NEJM199403313301302

Basson CT, Bachinsky DR, Lin RC, Levi T, Elkins JA, Soults J, Grayzel D, Kroumpouzou E, Traill TA, Leblanc-Straceski J, et al. 1997. Mutations in human TBX5 cause limb and cardiac malformation in Holt-Oram syndrome. Nat $\mathrm{Ge}$ net 15: 30-35. doi:10.1038/ng0197-30

Basson CT, Huang T, Lin RC, Bachinsky DR, Weremowicz S, Vaglio A, Bruzzone R, Quadrelli R, Lerone M, Romeo G, et al. 1999. Different TBX5 interactions in heart and limb defined by Holt-Oram syndrome mutations. Proc Natl Acad Sci 96: 2919-2924. doi:10.1073/pnas.96.6.2919

Battaglia A, Hoyme HE, Dallapiccola B, Zackai E, Hudgins L, McDonald-McGinn D, Bahi-Buisson N, Romano C, Williams CA, Brailey LL, et al. 2008a. Further delineation of deletion 1 p36 syndrome in 60 patients: a recognizable phenotype and common cause of developmental delay and mental retardation. Pediatrics 121: 404-410. doi:10 .1542/peds.2007-0929

Battaglia A, Filippi T, Carey JC. 2008b. Update on the clinical features and natural history of Wolf-Hirschhorn (4p-) syndrome: experience with 87 patients and recommendations for routine health supervision. Am J Med Genet Part C Semin Med Genet 148C: 246-251. doi:10.1002/ajmg.c .30187

Belmont JW, Mohapatra B, Towbin JA, Ware SM. 2004. Molecular genetics of heterotaxy syndromes. Curr Opin Cardiol 19: 216-220. doi:10.1097/00001573-20040500000005

Bensemlali M, Bajolle F, Ladouceur M, Fermont L, Lévy M, Le Bidois J, Salomon LJ, Bonnet D. 2016. Associated genetic syndromes and extracardiac malformations strongly influence outcomes of fetuses with congenital heart diseases. Arch Cardiovasc Dis 109: 330-336. doi:10.1016/j .acvd.2016.01.006

Benson DW, Silberbach GM, Kavanaugh-McHugh A, Cottrill C, Zhang Y, Riggs S, Smalls O, Johnson MC, Watson MS, Seidman JG, et al. 1999. Mutations in the cardiac transcription factor NKX2.5 affect diverse cardiac developmental pathways. J Clin Invest 104: 1567-1573. doi:10 $.1172 / \mathrm{JCI} 8154$

Bergmann C, Fliegauf M, Brüchle NO, Frank V, Olbrich H, Kirschner J, Schermer B, Schmedding I, Kispert A, Kränzlin B, et al. 2008. Loss of nephrocystin-3 function can cause embryonic lethality, Meckel-Gruber-like syndrome, situs inversus, and renal-hepatic-pancreatic dysplasia. Am J Hum Genet 82: 959-970. doi:10.1016/j.ajhg .2008.02.017

Bernier PL, Stefanescu A, Samoukovic G, Tchervenkov CI. 2010. The challenge of congenital heart disease worldwide: epidemiologic and demographic facts. Semin Thorac Cardiovasc Surg Pediatr Card Surg Annu 13: 26-34. doi:10.1053/j.pcsu.2010.02.005

Bernier R, Steinman KJ, Reilly B, Wallace AS, Sherr EH, Pojman N, Mefford HC, Gerdts J, Earl R, Hanson E, et al. 2016. Clinical phenotype of the recurrent 1q21.1 copynumber variant. Genet Med 18: 341-349. doi:10.1038/ $\operatorname{gim} .2015 .78$ 
Best KE, Rankin J. 2015. Increased risk of congenital heart disease in twins in the north of England between 1998 and 2010. Heart 101: 1807-1812. doi:10.1136/heartjnl-2015307826

Bittles AH, Bower C, Hussain R, Glasson EJ. 2007. The four ages of Down syndrome. Eur J Public Health 17: 221-225. doi:10.1093/eurpub/ckl103

Böhm J, Heinritz W, Craig A, Vujic M, Ekman-Joelsson BM, Kohlhase J, Froster U. 2008. Functional analysis of the novel TBX5 c.1333delC mutation resulting in an extended TBX5 protein. BMC Med Genet 9: 88. doi:10.1186/14712350-9-88

Boneva RS, Botto LD, Moore CA, Yang Q, Correa A, Erickson JD. 2001. Mortality associated with congenital heart defects in the United States. Circulation 103: 2376-2381. doi:10.1161/01.CIR.103.19.2376

Bostwick BL, McLean S, Posey JE, Streff HE, Gripp KW, Blesson A, Powell-Hamilton N, Tusi J, Stevenson DA, Farrelly E, et al. 2017. Phenotypic and molecular characterisation of CDK13-related congenital heart defects, dysmorphic facial features and intellectual developmental disorders. Genome Med 9: 73. doi:10.1186/s13073-0170463-8

Botto LD, May K, Fernhoff PM, Correa A, Coleman K, Rasmussen SA, Merritt RK, O'Leary LA, Wong LY, Elixson EM, et al. 2003. A population-based study of the 22q11.2 deletion: phenotype, incidence, and contribution to major birth defects in the population. Pediatrics 112: 101107. doi:10.1542/peds.112.1.101

Bouman A, Alders M, Oostra RJ, van Leeuwen E, Thuijs N, van der Kevie-Kersemaekers AM, van Maarle M. 2017. Oral-facial-digital syndrome type 1 in males: congenital heart defects are included in its phenotypic spectrum. Am $J$ Med Genet A 173: 1383-1389. doi:10.1002/ajmg.a .38179

Breckpot J, Thienpont B, Peeters H, de Ravel T, Singer A, Rayyan M, Allegaert K, Vanhole C, Eyskens B, Vermeesch JR, et al. 2010. Array comparative genomic hybridization as a diagnostic tool for syndromic heart defects. J Pediatr 156: 810-817.e4. doi:10.1016/j.jpeds.2009.11.049

Breckpot J, Thienpont B, Arens Y, Tranchevent LC, Vermeesch JR, Moreau Y, Gewillig M, Devriendt K. 2011. Challenges of interpreting copy number variation in syndromic and non-syndromic congenital heart defects. Cytogenet Genome Res 135: 251-259. doi:10.1159/ 000331272

Breckpot J, Thienpont B, Bauters M, Tranchevent LC, Gewillig M, Allegaert K, Vermeesch JR, Moreau Y, Devriendt K. 2012. Congenital heart defects in a novel recurrent 22q11.2 deletion harboring the genes CRKL and MAPK1. Am J Med Genet Part A 158A: 574-580. doi:10 .1002/ajmg.a.35217

Brodwall K, Greve G, Leirgul E, Tell GS, Vollset SE, Øyen N. 2017. Recurrence of congenital heart defects among siblings-a nationwide study. Am J Med Genet Part A 173: 1575-1585. doi:10.1002/ajmg.a.38237

Bucerzan S, Miclea D, Popp R, Alkhzouz C, Lazea C, Pop IV, Grigorescu-Sido P. 2017. Clinical and genetic characteristics in a group of 45 patients with Turner syndrome (monocentric study). Ther Clin Risk Manag 13: 613622. doi:10.2147/TCRM.S126301
Bull MJ; Committee on Genetics. 2011. Health supervision for children with Down syndrome. Pediatrics 128: $393-$ 406. doi:10.1542/peds.2011-1605

Burn J, Brennan P, Little J, Holloway S, Coffey R, Somerville J, Dennis NR, Allan L, Arnold R, Deanfield JE, et al. 1998. Recurrence risks in offspring of adults with major heart defects: results from first cohort of British collaborative study. Lancet 351: 311-316. doi:10.1016/S0140-6736(97) 06486-6

Campeau PM, Lu JT, Dawson BC, Fokkema IFAC, Robertson SP, Gibbs RA, Lee BH. 2012. The KAT6B-related disorders genitopatellar syndrome and Ohdo/SBBYS syndrome have distinct clinical features reflecting distinct molecular mechanisms. Hum Mutat 33: 1520-1525. doi:10.1002/humu.22141

Calcagni G, Digilio MC, Sarkozy A, Dallapiccola B, Marino B. 2006. Familial recurrence of congenital heart disease: an overview and review of the literature. Eur J Pediatr 166: 111-116. doi:10.1007/s00431-006-0295-9

Calzolari E, Garani G, Cocchi G, Magnani C, Rivieri F, Neville A, Astolfi G, Baroncini A, Garavelli L, Gualandi F, et al. 2003. Congenital heart defects: 15 years of experience of the Emilia-Romagna registry (Italy). Eur J Epidemiol 18: 773-780. doi:10.1023/A:1025312603880

Caputo S, Russo MG, Capozzi G, Morelli C, Argiento P, Di Salvo G, Sarubbi B, Santoro G, Pacileo G, Calabrò R. 2005. Congenital heart disease in a population of dizygotic twins: an echocardiographic study. Int J Cardiol 102: 293-296. doi:10.1016/j.ijcard.2004.05.018.

Carey AS, Liang LL, Edwards J, Brandt T, Mei H, Sharp AJ, Hsu DT, Newburger JW, Ohye RG, Chung WK, et al. 2013. Effect of copy number variants on outcomes for infants with single ventricle heart defects. Circ Cardiovasc Genet 6: 444-451. doi:10.1161/CIRCGENETICS.113 .000189.

Carta C, Pantaleoni F, Bocchinfuso G, Stella L, Vasta I, Sarkozy A, Digilio C, Palleschi A, Pizzuti A, Grammatico P, et al. 2006. Germline missense mutations affecting KRAS isoform $B$ are associated with a severe Noonan syndrome phenotype. Am J Hum Genet 79: 129-135. doi:10.1086/ 504394

Carter MT, Dyack S, Richer J. 2010. Distal trisomy 10q syndrome: phenotypic features in a child with inverted duplicated 10q25.1-q26.3. Clin Dysmorphol 19: 140-145 doi:10.1097/MCD.0b013e3283377915

Casas KA, Mononen TK, Mikail CN, Hassed SJ, Li S, Mulvihill JJ, Lin HJ, Falk RE. 2004. Chromosome 2q terminal deletion: report of 6 new patients and review of phenotype-breakpoint correlations in 66 individuals. $\mathrm{Am} \mathrm{J} \mathrm{Med}$ Genet A 130A: 331-339. doi:10.1002/ajmg.a.30156

Centers for Disease Control and Prevention (CDC). 2007. Hospital stays, hospital charges, and in-hospital deaths among infants with selected birth defects-United States, 2003. MMWR Morb Mortal Wkly Rep 56: 25-29.

Chen PC, Wakimoto H, Conner D, Araki T, Yuan T, Roberts A, Seidman CE, Bronson R, Neel BG, Seidman JG, et al. 2010. Activation of multiple signaling pathways causes developmental defects in mice with a Noonan syndrome-associated Sos1 mutation. J Clin Invest 120: 4353-4365. doi:10.1172/JCI43910

Chen M, Yang YS, Shih JC, Lin WH, Lee DJ, Lin YS, Chou $\mathrm{CH}$, Cameron AD, Ginsberg NA, Chen CA, et al. 2014. 
Microdeletions/duplications involving TBX1 gene in fetuses with conotruncal heart defects which are negative for 22q11.2 deletion on fluorescence in-situ hybridization. Ultrasound Obstet Gynecol 43: 396-403. doi:10 $.1002 /$ uog. 12550

Ciaccio C, Scuvera G, Tucci A, Gentilin B, Baccarin M, Marchisio P, Avignone S, Milani D. 2019. New insights into Kleefstra syndrome: report of two novel cases with previously unreported features and literature review. Cytogenet Genome Res 156: 127-133. doi:10.1159/ 000494532

Connor JA, Hinton RB, Miller EM, Sund KL, Ruschman JG Ware SM. 2014. Genetic testing practices in infants with congenital heart disease. Congenit Heart Dis 9: 158-167. doi:10.1111/chd.12112

Conway EE, Noonan J, Marion RW, Steeg CN. 1990. Myocardial infarction leading to sudden death in the Williams syndrome: report of three cases. J Pediatr 117: 593-595. doi:10.1016/S0022-3476(05)80696-1

Cordeddu V, Di Schiavi E, Pennacchio LA, Ma'ayan A, Sarkozy A, Fodale V, Cecchetti S, Cardinale A, Martin J, Schackwitz W, et al. 2009. Mutation of SHOC2 promotes aberrant protein $\mathrm{N}$-myristoylation and causes Noonanlike syndrome with loose anagen hair. Nat Genet 41: 1022-1026. doi:10.1038/ng.425

Cordell HJ, Bentham J, Topf A, Zelenika D, Heath S, Mamasoula C, Cosgrove C, Blue G, Granados-Riveron J Setchfield K, et al. 2013a. Genome-wide association study of multiple congenital heart disease phenotypes identifies a susceptibility locus for atrial septal defect at chromosome 4p16. Nat Genet 45: 822-824. doi:10.1038/ng.2637

Cordell HJ, Topf A, Mamasoula C, Postma AV, Bentham J, Zelenika D, Heath S, Blue G, Cosgrove C, Granados Riveron J, et al. 2013b. Genome-wide association study identifies loci on 12q24 and 13q32 associated with tetralogy of Fallot. Hum Mol Genet 22: 1473-1481. doi:10.1093/hmg/ dds552

Corsten-Janssen N, Kerstjens-Frederikse WS, du Marchie Sarvaas GJ, Baardman ME, Bakker MK, Bergman JEH, Hove HD, Heimdal KR, Rustad CF, Hennekam RCM, et al. 2013. The cardiac phenotype in patients with a CHD7 mutation. Circ Cardiovasc Genet 6: 248-254. doi:10.1161/ CIRCGENETICS.113.000054

Cowan JR, Ware SM. 2015. Genetics and genetic testing in congenital heart disease. Clin Perinatol 42: 373-393. doi:10.1016/j.clp.2015.02.009

Cowan J, Tariq M, Ware SM. 2014. Genetic and functional analyses of ZIC3 variants in congenital heart disease. Hum Mutat 35: 66-75. doi:10.1002/humu.22457

Cowan JR, Tariq M, Shaw C, Rao M, Belmont JW, Lalani SR, Smolarek TA, Ware SM. 2016. Copy number variation as a genetic basis for heterotaxy and heterotaxy-spectrum congenital heart defects. Philos Trans R Soc B Biol Sci 371: 20150406. doi:10.1098/rstb.2015.0406

Curran ME, Atkinson DL, Ewart AK, Morris CA, Leppert MF, Keating MT. 1993. The elastin gene is disrupted by a translocation associated with supravalvular aortic stenosis. Cell 73: 159-168. doi:10.1016/0092-8674(93)90168-P

Dagoneau N, Benoist-Lasselin C, Huber C, Faivre L, Mégarbané A, Alswaid A, Dollfus H, Alembik Y, Munnich A, Legeai-Mallet L, et al. 2004. ADAMTS10 mutations in autosomal recessive Weill-Marchesani syndrome. Am J Hum Genet 75: 801-806. doi:10.1086/425231

Dalrymple RA, Kenia P. 2018. European Respiratory Society guidelines for the diagnosis of primary ciliary dyskinesia: a guideline review. Arch Dis Child Educ Pract Ed 104: 265-269 edpract-2017-312902. doi:10.1136/archdis child-2017-312902

de Graaf G, Buckley F, Skotko BG. 2016. Live births, natural losses and elective terminations with Down syndrome in Massachusetts. Genet Med 18: 459-466. doi:10.1038/gim .2016 .15

de Graaf G, Buckley F, Dever J, Skotko BG. 2017. Estimation of live birth and population prevalence of Down syndrome in nine U.S. states. Am J Med Genet Part A 173: 2710-2719. doi:10.1002/ajmg.a.38402

Dell KM. 2011. The spectrum of polycystic kidney disease in children. Adv Chronic Kidney Dis 18: 339-347. doi:10 .1053/j.ackd.2011.05.001

Digilio M, Angioni A, De Santis M, Lombardo A, Giannotti A, Dallapiccola B, Marino B. 2003. Spectrum of clinical variability in familial deletion 22q11.2: from full manifestation to extremely mild clinical anomalies. Clin Genet 63: 308-313. doi:10.1034/j.1399-0004.2003.00049.x

Dimitrov B, Balikova I, de Ravel T, Van Esch H, De Smedt M, Baten E, Vermeesch JR, Bradinova I, Simeonov E, Devriendt $\mathrm{K}$, et al. 2011. 2q31.1 microdeletion syndrome: redefining the associated clinical phenotype. J Med Genet 48: 98-104. doi:10.1136/jmg.2010.079491

Donofrio MT, Moon-Grady AJ, Hornberger LK, Copel JA, Sklansky MS, Abuhamad A, Cuneo BF, Huhta JC, Jonas RA, Krishnan A, et al. 2014. Diagnosis and treatment of fetal cardiac disease: a scientific statement from the American Heart Association. Circulation 129: 2183 2242. doi:10.1161/01.cir.0000437597.44550.5d

Dugoff L, Mennuti MT, McDonald-McGinn DM. 2017. The benefits and limitations of cell-free DNA screening for 22q11.2 deletion syndrome. Prenat Diagn 37: 53-60. doi:10.1002/pd.4864

Egbe A, Uppu S, Stroustrup A, Lee S, Ho D, Srivastava S. 2014. Incidences and sociodemographics of specific congenital heart diseases in the United States of America: an evaluation of hospital discharge diagnoses. Pediatr Cardiol 35: 975-982. doi:10.1007/s00246-014-0884-8

El Bouchikhi I, Belhassan K, Moufid FZ, Iraqui Houssaini M, Bouguenouch L, Samri I, Atmani S, Ouldim K. 2016. Noonan syndrome-causing genes: molecular update and an assessment of the mutation rate. Int J Pediatr Adolesc Med 3: 133-142. doi:10.1016/j.ijpam.2016.06.003

Ellesøe SG, Johansen MM, Bjerre JV, Hjortdal VE, Brunak S, Larsen LA. 2016. Familial atrial septal defect and sudden cardiac death: identification of a novel NKX2-5 mutation and a review of the literature. Congenit Heart Dis 11: 283290. doi:10.1111/chd.12317

Embleton ND, Wyllie JP, Wright MJ, Burn J, Hunter S. 1996. Natural history of trisomy 18. Arch Dis Child Fetal Neonatal Ed 75: F38-F41. doi:10.1136/fn.75.1.F38

Emerick KM, Rand EB, Goldmuntz E, Krantz ID, Spinner NB, Piccoli DA. 1999. Features of Alagille syndrome in 92 patients: frequency and relation to prognosis. Hepatology 29: 822-829. doi:10.1002/hep.510290331

Erdogan F, Larsen LA, Zhang L, Tümer Z, Tommerup N, Chen W, Jacobsen JR, Schubert M, Jurkatis J, Tzschach A, 
et al. 2008. High frequency of submicroscopic genomic aberrations detected by tiling path array comparative genome hybridisation in patients with isolated congenital heart disease. J Med Genet 45: 704-709. doi:10.1136/jmg .2008 .058776

Eronen M, Peippo M, Hiippala A, Raatikka M, Arvio M, Johansson R, Kähkönen M. 2002. Cardiovascular manifestations in 75 patients with Williams syndrome. J Med Genet 39: 554-558 doi:10.1136/jmg.39.8.554.

Evans JM, Dharmar M, Meierhenry E, Marcin JP, Raff GW. 2014. Association between Down syndrome and in-hospital death among children undergoing surgery for congenital heart disease: a US population-based study. Circ Cardiovasc Qual Outcomes 7: 445-452. doi:10.1161/CIR COUTCOMES.113.000764

Ewart AK, Morris CA, Atkinson D, Jin W, Sternes K, Spallone P, Stock AD, Leppert M, Keating MT. 1993. Hemizygosity at the elastin locus in a developmental disorder, Williams syndrome. Nat Genet 5: 11-16. doi:10.1038/ ng0993-11

Fahed AC, Gelb BD, Seidman JG, Seidman CE. 2013. Genetics of congenital heart disease: the glass half empty. Circ Res 112: 707-720. doi:10.1161/CIRCRESAHA.112 .300853

Falk RE, Casas KA. 2007. Chromosome 2q37 deletion: clinical and molecular aspects. Am J Med Genet Part C Semin Med Genet 145C: 357-371. doi:10.1002/ajmg.c.30153

Fan C, Liu M, Wang Q. 2003. Functional analysis of TBX5 missense mutations associated with Holt-Oram syndrome. J Biol Chem 278: 8780-8785. doi:10.1074/jbc .M208120200

Ferencz C, Boughman JA, Neill CA, Brenner JI, Perry LW. 1989. Congenital cardiovascular malformations: questions on inheritance. J Am Coll Cardiol 14: 756-763. doi:10.1016/0735-1097(89)90122-8

Fixler DE, Pastor P, Chamberlin M, Sigman E, Eifler CW. 1990. Trends in congenital heart disease in Dallas County births. 1971-1984. Circulation 81: 137-142. doi:10.1161/ 01.CIR.81.1.137

Formigari R, Di Donato RM, Gargiulo G, Di Carlo D, Feltri C, Picchio FM, Marino B. 2004. Better surgical prognosis for patients with complete atrioventricular septal defect and Down's syndrome. Ann Thorac Surg 78: 666-672. doi:10.1016/j.athoracsur.2003.12.021

Forsythe E, Beales PL. 2013. Bardet-Biedl syndrome. Eur J Hum Genet 21: 8-13. doi:10.1038/ejhg.2012.115

Fradin M, Merklen-Djafri C, Perrigouard C, Aral B, Muller J, Stoetzel C, Frouin E, Flori E, Doray B, Dollfus H, et al. 2013. Long-term follow-up and molecular characterization of a patient with a RECQL4 mutation spectrum disorder. Dermatology 226: 353-357. doi:10.1159/000 351311

Freeman SB, Bean LH, Allen EG, Tinker SW, Locke AE, Druschel C, Hobbs CA, Romitti PA, Royle MH, Torfs CP, et al. 2008. Ethnicity, sex, and the incidence of congenital heart defects: a report from the National Down Syndrome Project. Genet Med 10: 173-180. doi:10.1097/ GIM.0b013e3181634867

Fudge JC, Li S, Jaggers J, O'Brien SM, Peterson ED, Jacobs JP, Welke KF, Jacobs ML, Li JS, Pasquali SK. 2010. Congenital heart surgery outcomes in down syndrome: analysis of a national clinical database. Pediatrics 126: 315-322. doi:10 .1542/peds.2009-3245

Gao B, Yao R, Zhao Z, Xie L, Xiang R, Hu X, Wang Z. 2005. [Expression and pathological implication of transforming growth factor- $\beta 1$ mRNA and endothelin- 1 mRNA in intraacinar pulmonary arterioles of congenital heart disease accompanied with pulmonary hypertension]. Chinese J Pathol 34: 159-162.

Garavelli L, Zollino M, Mainardi PC, Gurrieri F, Rivieri F, Soli F, Verri R, Albertini E, Favaron E, Zignani M, et al. 2009. Mowat-Wilson syndrome: facial phenotype changing with age: study of 19 Italian patients and review of the literature. Am J Med Genet A 149: 417-426. doi:10.1002/ ajmg.a.32693

Garg V, Kathiriya IS, Barnes R, Schluterman MK, King IN, Butler CA, Rothrock CR, Eapen RS, Hirayama-Yamada $\mathrm{K}$, Joo K, et al. 2003. GATA4 mutations cause human congenital heart defects and reveal an interaction with TBX5. Nature 424: 443-447. doi:10.1038/nature01827

Garg V, Muth AN, Ransom JF, Schluterman MK, Barnes R, King IN, Grossfeld PD, Srivastava D. 2005. Mutations in NOTCH1 cause aortic valve disease. Nature 437: $270-$ 274. doi: $10.1038 /$ nature 03940

Garrod AS, Zahid M, Tian X, Francis RJ, Khalifa O, Devine W, Gabriel GC, Leatherbury L, Lo CW. 2014. Airway ciliary dysfunction and sinopulmonary symptoms in patients with congenital heart disease. Ann Am Thorac Soc 11: 1426-1432. doi:10.1513/AnnalsATS.201405-222OC

Geddes GC, Basel D, Frommelt P, Kinney A, Earing M. 2017. Genetic testing protocol reduces costs and increases rate of genetic diagnosis in infants with congenital heart disease. Pediatr Cardiol 38: 1465-1470. doi:10.1007/s00246017-1685-7

Gelb BD. 2004. Genetic basis of congenital heart disease. Curr Opin Cardiol 19: 110-115. doi:10.1097/00001573200403000-00007

Gelb BD, Chung WK. 2014. Complex genetics and the etiology of human congenital heart disease. Cold Spring Harb Perspect Med 4: a013953. doi:10.1101/cshperspect .a013953

Gelb B, Brueckner M, Chung W, Goldmuntz E, Kaltman J, Kaski JP, Kim R, Kline J, Mercer-Rosa L, Porter G, et al. 2013. The congenital heart disease genetic network study: rationale, design, and early results. Circ Res 112: 698-706. doi:10.1161/CIRCRESAHA.111.300297

Gelb BD, Roberts AE, Tartaglia M. 2015. Cardiomyopathies in Noonan syndrome and the other RASopathies. Prog Pediatr Cardiol 39: 13-19. doi:10.1016/j.ppedcard.2015 .01 .002

Gil MM, Accurti V, Santacruz B, Plana MN, Nicolaides KH. 2017. Analysis of cell-free DNA in maternal blood in screening for aneuploidies: updated meta-analysis. Ultrasound Obstet Gynecol 50: 302-314. doi:10.1002/uog .17484

Gilboa SM, Salemi JL, Nembhard WN, Fixler DE, Correa A, Petrini J, Damus K, Johnston R, Petrini J, Damus K, et al. 2010. Mortality resulting from congenital heart disease among children and adults in the United States, 1999 to 2006. Circulation 122: 2254-2263. doi:10.1161/CIRCU LATIONAHA.110.947002

Gilboa SM, Devine OJ, Kucik JE, Oster ME, Riehle-Colarusso T, Nembhard WN, Xu P, Correa A, Jenkins K, Mar- 
elli AJ, et al. 2016. Congenital heart defects in the United States: estimating the magnitude of the affected population in 2010. Circulation 134: 101-109. doi:10.1161/CIR CULATIONAHA.115.019307

Gillis E, Kumar AA, Luyckx I, Preuss C, Cannaerts E, van de Beek G, Wieschendorf B, Alaerts M, Bolar N, Vandeweyer $\mathrm{G}$, et al. 2017. Candidate gene resequencing in a large bicuspid aortic valve-associated thoracic aortic aneurysm cohort: SMAD6 as an important contributor. Front Physiol 8: 400. doi:10.3389/fphys.2017.00400

Glessner JT, Bick AG, Ito K, Homsy JG, Rodriguez-Murillo L, Fromer M, Mazaika E, Vardarajan B, Italia M, Leipzig J, et al. 2014. Increased frequency of de novo copy number variants in congenital heart disease by integrative analysis of single nucleotide polymorphism array and exome sequence data. Circ Res 115: 884-896. doi:10.1161/CIRCRE SAHA.115.304458

Goh ES-Y, Li C, Horsburgh S, Kasai Y, Kolomietz E, Morel CF. 2010. The Roberts syndrome/SC phocomelia spectrum - a case report of an adult with review of the literature. Am J Med Genet A 152: 472-478. doi:10.1002/ajmg .a.33261

Goldmuntz E, Clark BJ, Mitchell LE, Jawad AF, Cuneo BF, Reed L, McDonald-McGinn D, Chien P, Feuer J, Zackai $\mathrm{EH}$, et al. 1998. Frequency of 22q11 deletions in patients with conotruncal defects. J Am Coll Cardiol 32: 492-498. doi:10.1016/S0735-1097(98)00259-9

Goldmuntz E, Paluru P, Glessner J, Hakonarson H, Biegel JA, White PS, Gai X, Shaikh TH. 2011. Microdeletions and microduplications in patients with congenital heart disease and multiple congenital anomalies. Congenit Heart Dis 6: 592-602. doi:10.1111/j.1747-0803.2011 .00582.x

Goldstein H, Nielsen KG. 2008. Rates and survival of individuals with trisomy 13 and 18 data from a 10 -year period in Denmark. Clin Genet 34: 366-372. doi:10.1111/j.13990004.1988.tb02894.x

Gøtzsche CO, Krag-Olsen B, Nielsen J, Sørensen KE, Kristensen BO. 1994. Prevalence of cardiovascular malformations and association with karyotypes in Turner's syndrome. Arch Dis Child 71: 433-436. doi:10.1136/adc.71 .5 .433

Grace MR, Hardisty E, Dotters-Katz SK, Vora NL, Kuller JA. 2016. Cell-free DNA screening: complexities and challenges of clinical implementation. Obstet Gynecol Surv 71: 477-487. doi:10.1097/OGX.0000000000000342

Grampa V, Delous M, Zaidan M, Odye G, Thomas S, Elkhartoufi N, Filhol E, Niel O, Silbermann F, Lebreton C, et al. 2016. Novel NEK8 mutations cause severe syndromic renal cystic dysplasia through YAP dysregulation. PLoS Genet 12: e1005894. doi:10.1371/journal.pgen.1005894

Granados-Riveron JT, Ghosh TK, Pope M, Bu'Lock F, Thornborough C, Eason J, Kirk EP, Fatkin D, Feneley MP, Harvey RP, et al. 2010. $\alpha$-Cardiac myosin heavy chain (MYH6) mutations affecting myofibril formation are associated with congenital heart defects. Hum Mol Genet 19: 4007-4016. doi:10.1093/hmg/ddq315

Granadillo JL, Chung WK, Hecht L, Corsten-Janssen N, Wegner D, Nij Bijvank SWA, Toler TL, Pineda-Alvarez DE, Douglas G, Murphy JJ, et al. 2018. Variable cardiovascular phenotypes associated with SMAD2 pathogenic variants. Hum Mutat 39: 1875-1884. doi:10.1002/humu .23627

Grange DK, Lorch SM, Cole PL, Singh GK. 2006. Cantu syndrome in a woman and her two daughters: further confirmation of autosomal dominant inheritance and review of the cardiac manifestations. Am J Med Genet A 140: 1673-1680. doi:10.1002/ajmg.a.31348

Gravholt CH, Andersen NH, Conway GS, Dekkers OM, Geffner ME, Klein KO, Lin AE, Mauras N, Quigley CA, Rubin K, et al. 2017. Clinical practice guidelines for the care of girls and women with Turner syndrome: proceedings from the 2016 Cincinnati International Turner Syndrome Meeting. Eur J Endocrinol 177: G1-G70. doi:10 1530/EJE-17-0430

Grech V, Gatt M. 1999. Syndromes and malformations associated with congenital heart disease in a populationbased study. Int J Cardiol 68: 151-156. doi:10.1016/ S0167-5273(98)00354-4

Griffin HR, Töpf A, Glen E, Zweier C, Stuart AG, Parsons J, Peart I, Deanfield J, O'Sullivan J, Rauch A, et al. 2010. Systematic survey of variants in TBX1 in non-syndromic tetralogy of Fallot identifies a novel 57 base pair deletion that reduces transcriptional activity but finds no evidence for association with common variants. Heart 96: 16511655. doi:10.1136/hrt.2010.200121

Gripp KW, Hopkins E, Jenny K, Thacker D, Salvin J. 2013. Cardiac anomalies in Axenfeld-Rieger syndrome due to a novel FOXC1 mutation. Am J Med Genet A 161: 114-119. doi:10.1002/ajmg.a.35697

Grossfeld PD, Mattina T, Lai Z, Favier R, Jones KL, Cotter F, Jones C. 2004. The 11q terminal deletion disorder: a prospective study of 110 cases. Am J Med Genet 129A: 51-61. doi:10.1002/ajmg.a.30090

Guo Y, Shen J, Yuan L, Li F, Wang J, Sun K. 2010. Novel CRELD1 gene mutations in patients with atrioventricular septal defect. World J Pediatr 6: 348-352. doi:10.1007/ s12519-010-0235-7

Hahn A, Lauriol J, Thul J, Behnke-Hall K, Logeswaran T, Schänzer A, Böğürcü N, Garvalov BK, Zenker M, Gelb BD, et al. 2015. Rapidly progressive hypertrophic cardiomyopathy in an infant with Noonan syndrome with multiple lentigines: palliative treatment with a rapamycin analog. Am J Med Genet Part A 167: 744-751. doi:10.1002/ ajmg.a.36982

Hamilton MJ, Caswell RC, Canham N, Cole T, Firth HV, Foulds N, Heimdal K, Hobson E, Houge G, Joss S, et al. 2018. Heterozygous mutations affecting the protein kinase domain of $C D K 13$ cause a syndromic form of developmental delay and intellectual disability. J Med Genet 55: 28-38. doi:10.1136/jmedgenet-2017-104620

Hanchard NA, Swaminathan S, Bucasas K, Furthner D, Fernbach S, Azamian MS, Wang X, Lewin M, Towbin JA, D'Alessandro LCA, et al. 2016. A genome-wide association study of congenital cardiovascular left-sided lesions shows association with a locus on chromosome 20. Hum Mol Genet 25: 2331-2341. doi:10.1093/hmg/ ddw071

Hanna EJ, Nevin NC, Nelson J. 1994. Genetic study of congenital heart defects in Northern Ireland (1974-1978). J Med Genet 31: 858-863. doi:10.1136/jmg.31.11.858

Hannibal MC, Buckingham KJ, Ng SB, Ming JE, Beck AE, McMillin MJ, Gildersleeve HI, Bigham AW, Tabor HK, 
Mefford HC, et al. 2011. Spectrum of MLL2 (ALR) mutations in 110 cases of Kabuki syndrome. Am J Med Genet A 155: 1511-1516. doi:10.1002/ajmg.a.34074

Hartman RJ, Rasmussen SA, Botto LD, Riehle-Colarusso T, Martin CL, Cragan JD, Shin M, Correa A. 2011. The contribution of chromosomal abnormalities to congenital heart defects: a population-based study. Pediatr Cardiol 32: 1147-1157. doi:10.1007/s00246-011-0034-5

Hassed S, Li S, Mulvihill J, Aston C, Palmer S. 2017. AdamsOliver syndrome review of the literature: refining the diagnostic phenotype. Am J Med Genet A 173: 790-800. doi:10.1002/ajmg.a.37889

Hasten E, McDonald-McGinn DM, Crowley TB, Zackai E, Emanuel BS, Morrow BE, Racedo SE. 2018. Dysregulation of TBX1 dosage in the anterior heart field results in congenital heart disease resembling the 22q11.2 duplication syndrome. Hum Mol Genet 27: 1847-1857. doi:10.1093/ hmg/ddy078

Hennekam RCM. 2006. Rubinstein-Taybi syndrome. Eur J Hum Genet 14: 981-985. doi:10.1038/sj.ejhg.5201594

Herskind AM, Almind Pedersen D, Christensen K. 2013. Increased prevalence of congenital heart defects in monozygotic and dizygotic twins. Circulation 128: 1182-1188. doi:10.1161/CIRCULATIONAHA.113.002453

Hills C, Moller JH, Finkelstein M, Lohr J, Schimmenti L. 2006. Cri du chat syndrome and congenital heart disease: a review of previously reported cases and presentation of an additional 21 cases from the Pediatric Cardiac Care Consortium. Pediatrics 117: e924-e927. doi:10.1542/peds $.2005-1012$

Hilton E, Johnston J, Whalen S, Okamoto N, Hatsukawa Y, Nishio J, Kohara H, Hirano Y, Mizuno S, Torii C, et al. 2009. BCOR analysis in patients with OFCD and Lenz microphthalmia syndromes, mental retardation with ocular anomalies, and cardiac laterality defects. Eur J Hum Genet 17: 1325-1335. doi:10.1038/ejhg.2009.52

Hinton RB, Martin LJ, Tabangin ME, Mazwi ML, Cripe LH, Benson DW. 2007. Hypoplastic left heart syndrome is heritable. J Am Coll Cardiol 50: 1590-1595. doi:10 $.1016 /$ j.jacc.2007.07.021

Hoffman JI, Kaplan S. 2002. The incidence of congenital heart disease. J Am Coll Cardiol 39: 1890-1900. doi:10 .1016/S0735-1097(02)01886-7

Holt M, Oram S. 1960. Familial heart disease with skeletal malformations. Br Heart J 22: 236-242. doi:10.1136/hrt .22 .2 .236

Holtzinger A, Rosenfeld GE, Evans T. 2010. Gata4 directs development of cardiac-inducing endoderm from ES cells. Dev Biol 337: 63-73. doi:10.1016/j.ydbio.2009.10 .003

Homsy J, Zaidi S, Shen Y, Ware JS, Samocha KE, Karczewski KJ, DePalma SR, McKean D, Wakimoto H, Gorham J, et al. 2015. De novo mutations in congenital heart disease with neurodevelopmental and other congenital anomalies. Science 350: 1262-1266. doi:10.1126/science.aac9396

Horn D, Chyrek M, Kleier S, Lüttgen S, Bolz H, Hinkel G-K, Korenke GC, Rieß A, Schell-Apacik C, Tinschert S, et al. 2005. Novel mutations in BCOR in three patients with oculo-facio-cardio-dental syndrome, but none in Lenz microphthalmia syndrome. Eur J Hum Genet 13: 563569. doi:10.1038/sj.ejhg.5201391
Huang RT, Wang J, Xue S, Qiu XB, Shi HY, Li RG, Qu XK, Yang XX, Liu H, Li N, et al. 2017. TBX20 loss-of-function mutation responsible for familial tetralogy of Fallot or sporadic persistent truncus arteriosus. Int J Med Sci 14: 323-332. doi:10.7150/ijms.17834.

Huret JL, Leonard C, Forestier B, Rethoré MO, Lejeune J. 1988. Eleven new cases of del $(9 \mathrm{p})$ and features from 80 cases. J Med Genet 25: 741-749. doi:10.1136/jmg.25.11 .741

Incecik F, Hergüner OM, Alinç Erdem S, Altunbasak S. 2015. Neurofibromatosis type 1 and cardiac manifestations. Turk Kardiyol Dern Ars 43: 714-716. doi:10.5543/tkda .2015 .27557

Inoue $\mathrm{S}$, Moriya $\mathrm{M}$, Watanabe $\mathrm{Y}$, Miyagawa-Tomita S, Niihori T, Oba D, Ono M, Kure S, Ogura T, Matsubara Y, et al. 2014. New BRAF knockin mice provide a pathogenetic mechanism of developmental defects and a therapeutic approach in cardio-facio-cutaneous syndrome. Hum Mol Genet 23: 6553-6566. doi:10.1093/hmg/ddu376

Ip P, Chiu CSW, Cheung YF. 2002. Risk factors prolonging ventilation in young children after cardiac surgery: impact of noninfectious pulmonary complications. Pediatr Crit Care Med 3: 269-274. doi:10.1097/00130478-20020700000013

Ito S, Chapman KA, Kisling M, John AS. 2017. Appropriate use of genetic testing in congenital heart disease patients. Curr Cardiol Rep 19: 24. doi:10.1007/s11886-017-0834-1

Ivy DD, Shaffer EM, Johnson AM, Kimberling WJ, Dobin A, Gabow PA. 1995. Cardiovascular abnormalities in children with autosomal dominant polycystic kidney disease. J Am Soc Nephrol 5: 2032-2036.

Izumi K, Hayashi D, Grochowski CM, Kubota N, Nishi E, Arakawa M, Hiroma T, Hatata T, Ogiso Y, Nakamura T, et al. 2016. Discordant clinical phenotype in monozygotic twins with Alagille syndrome: possible influence of nongenetic factors. Am J Med Genet Part A 170: 471-475. doi:10.1002/ajmg.a.37429

Jenkins D, Seelow D, Jehee FS, Perlyn CA, Alonso LG, Bueno DF, Donnai D, Josifiova D, Mathijssen IMJ, Morton JEV, et al. 2007. RAB23 mutations in Carpenter syndrome imply an unexpected role for hedgehog signaling in cranialsuture development and obesity. Am J Hum Genet 80: 1162-1170. doi:10.1086/518047

Jerome LA, Papaioannou VE. 2001. DiGeorge syndrome phenotype in mice mutant for the T-box gene, Tbx1. Nat Genet 27: 286-291. doi:10.1038/85845

Jhang WK, Choi JH, Lee BH, Kim GH, Yoo HW. 2016. Cardiac manifestations and associations with gene mutations in patients diagnosed with RASopathies. Pediatr Cardiol 37: 1539-1547. doi:10.1007/s00246-016-1468-6

Jiang J-Q, Li R-G, Wang J, Liu XY, Xu YJ, Fang WY, Chen XZ, Zhang W, Wang XZ, Yang YQ. 2013. Prevalence and spectrum of GATA5 mutations associated with congenital heart disease. Int J Cardiol 165: 570-573. doi:10.1016/j .ijcard.2012.09.039

Jiang T, Huang M, Jiang T, Gu Y, Wang Y, Wu Y, Ma H, Jin G, Dai J, Hu Z. 2018. Genome-wide compound heterozygosity analysis highlighted 4 novel susceptibility loci for congenital heart disease in Chinese population. $\mathrm{Clin} \mathrm{Ge}$ net 94: 296-302. doi:10.1111/cge.13384

Jin SC, Homsy J, Zaidi S, Lu Q, Morton S, DePalma SR, Zeng X, Qi H, Chang W, Sierant MC, et al. 2017. Contribution 
of rare inherited and de novo variants in 2,871 congenital heart disease probands. Nat Genet 49: 1593-1601. doi:10 $.1038 /$ ng. 3970

Jones KL, Jones MC, Del Campo M. 2013. Smith's recognizable patterns of human malformation. In Smith's recognizable patterns of human malformation, 7th ed., pp. 783. Elsevier, New York.

Kaasinen E, Aittomaki K, Eronen M, Vahteristo P, Karhu A, Mecklin JP, Kajantie E, Aaltonen LA, Lehtonen R. 2010 Recessively inherited right atrial isomerism caused by mutations in growth/differentiation factor 1 (GDF1) Hum Mol Genet 19: 2747-2753. doi:10.1093/hmg/ ddq164

Kadakia S, Helman SN, Healy NJ, Saman M, Wood-Smith D. 2014. Carpenter syndrome: a review for the craniofacial surgeon. J Craniofac Surg 25: 1653-1657. doi:10.1097/ SCS.0000000000001121

Kamath BM, Bason L, Piccoli DA, Krantz ID, Spinner NB. 2003. Consequences of JAG1 mutations. J Med Genet 40: 891-895. doi:10.1136/jmg.40.12.891

Kamath BM, Spinner NB, Emerick KM, Chudley AE, Booth C, Piccoli DA, Krantz ID. 2004. Vascular anomalies in Alagille syndrome. Circulation 109: 1354-1358. doi:10 .1161/01.CIR.0000121361.01862.A4

Kamath BM, Bauer RC, Loomes KM, Chao G, Gerfen J, Hutchinson A, Hardikar W, Hirschfield G, Jara P, Krantz ID, et al. 2012. NOTCH2 mutations in Alagille syndrome. J Med Genet 49: 138-144. doi:10.1136/jmedgenet-2011100544

Karkera JD, Lee JS, Roessler E, Banerjee-Basu S, Ouspenskaia M V, Mez J, Goldmuntz E, Bowers P, Towbin J, Belmont JW, et al. 2007. Loss-of-function mutations in growth differentiation factor-1 (GDF1) are associated with congenital heart defects in humans. Am J Hum Genet 81: 987-994. doi:10.1086/522890

Kececioglu D, Kotthoff S, Vogt J. 1993. Williams-Beuren syndrome: a 30-year follow-up of natural and postoperative course. Eur Heart J 14: 1458-1464. doi:10.1093/eu rheartj/14.11.1458

Kennedy MP, Omran H, Leigh MW, Dell S, Morgan L, Molina PL, Robinson B V, Minnix SL, Olbrich H, Severin T, et al. 2007. Congenital heart disease and other heterotaxic defects in a large cohort of patients with primary ciliary dyskinesia. Circulation 115: 2814-2821. doi:10.1161/CIR CULATIONAHA.106.649038

Kerstjens-Frederikse WS, van de Laar IMBH, Vos YJ, Verhagen JMA, Berger RMF, Lichtenbelt KD, Klein WassinkRuiter JS, van der Zwaag PA, du Marchie Sarvaas GJ, Bergman KA, et al. 2016. Cardiovascular malformations caused by NOTCH1 mutations do not keep left: data on 428 probands with left-sided $\mathrm{CHD}$ and their families. Genet Med 18: 914-923.

Khairy P, Ionescu-Ittu R, Mackie AS, Abrahamowicz M, Pilote L, Marelli AJ. 2010. Changing mortality in congenital heart disease. J Am Coll Cardiol 56: 1149-1157. doi:10 $.1016 /$ j.jacc.2010.03.085

Kidd SA, Lachiewicz A, Barbouth D, Blitz RK, Delahunty C, McBrien D, Visootsak J, Berry-Kravis E. 2014. Fragile X syndrome: a review of associated medical problems. $P e-$ diatrics 134: 995-1005. doi:10.1542/peds.2013-4301

Kim DS, Kim JH, Burt AA, Crosslin DR, Burnham N, Kim CE, McDonald-McGinn DM, Zackai EH, Nicolson SC,
Spray TL, et al. 2016. Burden of potentially pathologic copy number variants is higher in children with isolated congenital heart disease and significantly impairs covariate-adjusted transplant-free survival. J Thorac Cardiovasc Surg 151: 1147-1151.e4. doi:10.1016/j.jtcvs.2015.09 .136

Kirk EP, Sunde M, Costa MW, Rankin SA, Wolstein O, Castro ML, Butler TL, Hyun C, Guo G, Otway R, et al. 2007. Mutations in cardiac T-box factor gene TBX20 are associated with diverse cardiac pathologies, including defects of septation and valvulogenesis and cardiomyopathy. Am J Hum Genet 81: 280-291. doi:10.1086/519530

Kleefstra T, Brunner HG, Amiel J, Oudakker AR, Nillesen WM, Magee A, Geneviève D, Cormier-Daire V, van Esch H, Fryns JP, et al. 2006. Loss-of-function mutations in Euchromatin Histone Methyl Transferase 1 (EHMT1) cause the $9 \mathrm{q} 34$ subtelomeric deletion syndrome. Am J Hum Genet 79: 370-377. doi:10.1086/505693

Kleefstra T, van Zelst-Stams WA, Nillesen WM, CormierDaire V, Houge G, Foulds N, van Dooren M, Willemsen MH, Pfundt R, Turner A, et al. 2009. Further clinical and molecular delineation of the $9 \mathrm{q}$ subtelomeric deletion syndrome supports a major contribution of EHMT1 haploinsufficiency to the core phenotype. J Med Genet 46: 598-606. doi:10.1136/jmg.2008.062950

Klena NT, Gibbs BC, Lo CW. 2017. Cilia and ciliopathies in congenital heart disease. Cold Spring Harb Perspect Biol 9: a028266. doi:10.1101/cshperspect.a028266

Kodo K, Nishizawa T, Furutani M, Arai S, Yamamura E, Joo K, Takahashi T, Matsuoka R, Yamagishi H. 2009. GATA6 mutations cause human cardiac outflow tract defects by disrupting semaphorin-plexin signaling. Proc Natl Acad Sci 106: 13933-13938. doi:10.1073/pnas.0904744106

Kodo K, Nishizawa T, Furutani M, Arai S, Ishihara K, Oda M, Makino S, Fukuda K, Takahashi T, Matsuoka R, et al. 2012. Genetic analysis of essential cardiac transcription factors in 256 patients with non-syndromic congenital heart defects. Circ J 76: 1703-1711. doi:10.1253/circj .CJ-11-1389

Kojuri J, Razeghinejad MR, Aslani A. 2007. Cardiac findings in Weill-Marchesani syndrome. Am J Med Genet A 143: 2062-2064. doi:10.1002/ajmg.a.31861

Koolen DA, Sharp AJ, Hurst JA, Firth HV, Knight SJ, Goldenberg A, Saugier-Veber P, Pfundt R, Vissers LE, Destrée A, et al. 2008. Clinical and molecular delineation of the 17q21.31 microdeletion syndrome. J Med Genet 45: 710720. doi:10.1136/jmg.2008.058701

Koolen DA, Pfundt R, Linda K, Beunders G, Veenstra-Knol HE, Conta JH, Fortuna AM, Gillessen-Kaesbach G, Dugan S, Halbach S, et al. 2016. The Koolen-de Vries syndrome: a phenotypic comparison of patients with a 17q21.31 microdeletion versus a KANSL1 sequence variant. Eur J Hum Genet 24: 652-659. doi:10.1038/ejhg .2015 .178

Kosho T, Okamoto N; Coffin-Siris Syndrome International Collaborators. 2014. Genotype-phenotype correlation of Coffin-Siris syndrome caused by mutations in SMARCB1, SMARCA4, SMARCE1, and ARIDIA. Am J Med Genet C Semin Med Genet 166: 262-275. doi:10 $.1002 /$ ajmg.c. 31407

Kouz K, Lissewski C, Spranger S, Mitter D, Riess A, LopezGonzalez V, Lüttgen S, Aydin H, von Deimling F, Evers C, 
et al. 2016. Genotype and phenotype in patients with Noonan syndrome and a RIT1 mutation. Genet Med 18: 1226-1234. doi:10.1038/gim.2016.32

Kuo CF, Lin YS, Chang SH, Chou IJ, Luo SF, See LC, Yu KH, Huang LS, Chu PH. 2018. Familial aggregation and heritability of congenital heart defects. Circ J 82: 232-238. doi:10.1253/circj.CJ-17-0250

Lacro RV, Jones KL, Benirschke K. 1988. Coarctation of the aorta in Turner syndrome: a pathologic study of fetuses with nuchal cystic hygromas, hydrops fetalis, and female genitalia. Pediatrics 81: 445-451.

LaHaye S, Corsmeier D, Basu M, Bowman JL, FitzgeraldButt S, Zender G, Bosse K, McBride KL, White P, Garg V. 2016. Utilization of whole exome sequencing to identify causative mutations in familial congenital heart disease. Circ Cardiovasc Genet 9: 320-329. doi:10.1161/ CIRCGENETICS.115.001324

Lal PS, Chavan B, Devendran VR, Varghese R, Murmu UC, Kumar RS. 2013. Surgical outcome of congenital heart disease in Down's syndrome. Asian Cardiovasc Thorac Ann 21: 166-169. doi:10.1177/0218492312450701

Landis BJ, Cooper DS, Hinton RB. 2016. CHD associated with syndromic diagnoses: peri-operative risk factors and early outcomes. Cardiol Young 26: 30-52. doi:10.1017/ S1047951115001389

Lange R, Guenther T, Busch R, Hess J, Schreiber C. 2007. The presence of Down syndrome is not a risk factor in complete atrioventricular septal defect repair. J Thorac Cardiovasc Surg 134: 304-310. doi:10.1016/j.jtcvs.2007.01 .026

Latham GJ, Ross FJ, Eisses MJ, Richards MJ, Geiduschek JM, Joffe DC. 2016. Perioperative morbidity in children with elastin arteriopathy. Pediatr Anesth 26: 926-935. doi:10 $.1111 /$ pan. 12967

Lazier J, Fruitman D, Lauzon J, Bernier F, Argiropoulos B, Chernos J, Caluseriu O, Simrose R, Thomas MA. 2016. Prenatal array comparative genomic hybridization in fetuses with structural cardiac anomalies. J Obstet Gynaecol Can 38: 619-626. doi:10.1016/j.jogc.2016.02.010

Lederer D, Grisart B, Digilio MC, Benoit V, Crespin M, Ghariani SC, Maystadt I, Dallapiccola B, Verellen-Dumoulin C. 2012. Deletion of KDM6A, a histone demethylase interacting with MLL2, in three patients with Kabuki syndrome. Am J Hum Genet 90: 119-124. doi:10.1016/j .ajhg.2011.11.021

Lee K, Khoshnood B, Chen L, Wall SN, Cromie WJ, Mittendorf RL. 2001. Infant mortality from congenital malformations in the United States, 1970-1997. Obstet Gynecol 98: 620-627.

Lehalle D, Gordon CT, Oufadem M, Goudefroye G, Boutaud L, Alessandri J-L, Baena N, Baujat G, Baumann C, BouteBenejean O, et al. 2014. Delineation of EFTUD2 haploinsufficiency-related phenotypes through a series of 36 patients. Hum Mutat 35: 478-485. doi:10.1002/humu .22517

Leppävirta J, Kallionpää RA, Uusitalo E, Vahlberg T, Pöyhönen M, Peltonen J, Peltonen S. 2018. Congenital anomalies in neurofibromatosis 1: a retrospective register-based total population study. Orphanet J Rare Dis 13: 5. doi:10 .1186/s13023-017-0756-4

Lesnik Oberstein SAJ, Kriek M, White SJ, Kalf ME, Szuhai K, den Dunnen JT, Breuning MH, Hennekam RCM. 2006.
Peters Plus syndrome is caused by mutations in B3GALTL, a putative glycosyltransferase. Am J Hum Genet 79: 562-566. doi:10.1086/507567

Leventopoulos G, Kitsiou-Tzeli S, Kritikos K, Psoni S, Mavrou A, Kanavakis E, Fryssira H. 2009. A clinical study of Sotos syndrome patients with review of the literature. Pediatr Neurol 40: 357-364. doi:10.1016/J .PEDIATRNEUROL.2008.11.013

Li D, Toland AE, Boak BB, Atkinson DL, Ensing GJ, Morris CA, Keating MT. 1997a. Elastin point mutations cause an obstructive vascular disease, supravalvular aortic stenosis. Hum Mol Genet 6: 1021-1028. doi:10.1093/hmg/6.7.1021

Li L, Krantz ID, Deng Y, Genin A, Banta AB, Collins CC, Qi M, Trask BJ, Kuo WL, Cochran J, et al. 1997b. Alagille syndrome is caused by mutations in human Jagged1, which encodes a ligand for Notch1. Nat Genet 16: 243251. doi:10.1038/ng0797-243

Li QY, Newbury-Ecob RA, Terrett JA, Wilson DI, Curtis ARJ, Ho Yi C, Gebuhr T, Bullen PJ, Robson SC, Strachan T, et al. 1997c. Holt-Oram syndrome is caused by mutations in TBX5, a member of the Brachyury (T) gene family. Nat Genet 15: 21-29. doi:10.1038/ng0197-21

Li Y, Klena NT, Gabriel GC, Liu X, Kim AJ, Lemke K, Chen Y, Chatterjee B, Devine W, Damerla RR, et al. 2015. Global genetic analysis in mice unveils central role for cilia in congenital heart disease. Nature 521: 520-524. doi:10 $.1038 /$ nature 14269

Liberalesso PBN, Cordeiro ML, Karuta SCV, Koladicz KRJ, Nitsche A, Zeigelboim BS, Raskin S, Rauchman M. 2017. Phenotypic and genotypic aspects of Townes-Brock syndrome: case report of patient in southern Brazil with a new SALL1 hotspot region nonsense mutation. BMC Med Genet 18: 125. doi:10.1186/s12881-017-0483-7

Limongelli G, Pacileo G, Marino B, Digilio MC, Sarkozy A, Elliott P, Versacci P, Calabro P, De Zorzi A, Di Salvo G, et al. 2007. Prevalence and clinical significance of cardiovascular abnormalities in patients with the LEOPARD syndrome. Am J Cardiol 100: 736-741. doi:10.1016/j .amjcard.2007.03.093

Lin HY, Lin SP, Chen YJ, Hsu CH, Kao HA, Chen MR, Hung HY, Ho CS, Chang JH, Huang FY, et al. 2007. Clinical characteristics and survival of trisomy 13 in a medical center in Taiwan, 1985-2004. Pediatr Int 49: 380-386. doi:10.1111/j.1442-200X.2007.02377.x

Lin AE, Krikov S, Riehle-Colarusso T, Frías JL, Belmont J, Anderka M, Geva T, Getz KD, Botto LD. 2014. Laterality defects in the national birth defects prevention study (1998-2007): birth prevalence and descriptive epidemiology. Am J Med Genet Part A 164: 2581-2591. doi:10 .1002/ajmg.a.36695

Lin AE, Ardinger HH, Ardinger RH, Cunniff C, Kelley RI. 1997. Cardiovascular malformations in Smit-LemliOpitz syndrome. Am J Med Genet 68: 270-278.

Lin AE, Birch PH, Korf BR, Tenconi R, Niimura M, Poyhonen M, Armfield Uhas K, Sigorini M, Virdis R, Romano C, et al. 2000. Cardiovascular malformations and other cardiovascular abnormalities in neurofibromatosis $1 . \mathrm{Am}$ J Med Genet 95: 108-117.

Lin AE, Alexander ME, Colan SD, Kerr B, Rauen KA, Noonan J, Baffa J, Hopkins E, Sol-Church K, Limongelli $\mathrm{G}$, et al. 2011. Clinical, pathological, and molecular analyses of cardiovascular abnormalities in Costello syn- 
drome: a Ras/MAPK pathway syndrome. Am J Med Genet A 155: 486-507. doi:10.1002/ajmg.a.33857

Lin AE, Michot C, Cormier-Daire V, L'Ecuyer TJ, Matherne GP, Barnes BH, Humberson JB, Edmondson AC, Zackai E, O'Connor MJ, et al. 2016. Gain-of-function mutations in SMAD4 cause a distinctive repertoire of cardiovascular phenotypes in patients with Myhre syndrome. Am J Med Genet A 170: 2617-2631. doi:10.1002/ajmg.a.37739

Lindstrand A, Malmgren H, Verri A, Benetti E, Eriksson M, Nordgren A, Anderlid BM, Golovleva I, Schoumans J, Blennow E. 2010. Molecular and clinical characterization of patients with overlapping $10 \mathrm{p}$ deletions. Am J Med Genet Part A 152A: 1233-1243. doi:10.1002/ajmg.a .33366

Lines MA, Huang L, Schwartzentruber J, Douglas SL, Lynch DC, Beaulieu C, Guion-Almeida ML, Zechi-Ceide RM, Gener B, Gillessen-Kaesbach G, et al. 2012. Haploinsufficiency of a spliceosomal GTPase encoded by EFTUD2 causes mandibulofacial dysostosis with microcephaly. Am J Hum Genet 90: 369-377. doi:10.1016/j.ajhg.2011 .12 .023

Loffredo CA, Chokkalingam A, Sill AM, Boughman JA, Clark EB, Scheel J, Brenner JI. 2004. Prevalence of congenital cardiovascular malformations among relatives of infants with hypoplastic left heart, coarctation of the aorta, and d-transposition of the great arteries. Am J Med Genet 124A: 225-230. doi:10.1002/ajmg.a.20366

Loughborough WW, Minhas KS, Rodrigues JCL, Lyen SM, Burt HE, Manghat NE, Brooks MJ, Stuart G, Hamilton MCK. 2018. Cardiovascular manifestations and complications of Loeys-Dietz syndrome: CT and MR imaging findings. Radiographics 38: 275-286. doi:10.1148/rg .2018170120

Lu F, Morrissette JJD, Spinner NB. 2003. Conditional JAG1 mutation shows the developing heart is more sensitive than developing liver to JAG1 dosage. Am J Hum Genet 72: 1065-1070. doi:10.1086/374386

MacCarrick G, Black JH, Bowdin S, El-Hamamsy I, Frischmeyer-Guerrerio PA, Guerrerio AL, Sponseller PD, Loeys B, Dietz HC. 2014. Loeys-Dietz syndrome: a primer for diagnosis and management. Genet Med 16: 576-587. doi:10.1038/gim.2014.11

Maillette de Buy Wenniger-Prick LJJM, Hennekam RCM. 2002. The Peters' plus syndrome: a review. Ann Genet 45: 97-103. doi:10.1016/S0003-3995(02)01120-6

Marcadier JL, Mears AJ, Woods EA, Fisher J, Airheart C, Qin W, Beaulieu CL, Dyment DA, Innes AM, Curry CJ, et al. 2016. A novel mutation in two Hmong families broadens the range of STRA6-related malformations to include contractures and camptodactyly. Am J Med Genet A 170: 11-18. doi:10.1002/ajmg.a.37389

Mazzeu JF, Pardono E, Vianna-Morgante AM, Richieri-Costa A, Ae Kim C, Brunoni D, Martelli L, de Andrade CEF, Colin G, Otto PA. 2007. Clinical characterization of autosomal dominant and recessive variants of Robinow syndrome. Am J Med Genet A 143: 320-325. doi:10.1002/ ajmg.a.31592

Malec E, Mroczek T, Pajak J, Januszewska K, Zdebska E. 1999. Results of surgical treatment of congenital heart defects in children with Down's syndrome. Pediatr Cardiol 20: 351-354. doi:10.1007/s002469900483
Manning N, Archer N. 2006. A study to determine the incidence of structural congenital heart disease in monochorionic twins. Prenat Diagn 26: 1062-1064. doi:10.1002/pd .1556

Manning M, Hudgins L. 2010. Array-based technology and recommendations for utilization in medical genetics practice for detection of chromosomal abnormalities. Genet Med 12: 742-745. doi:10.1097/GIM.0b013e3181 f8baad

Marelli AJ, Mackie AS, Ionescu-Ittu R, Rahme E, Pilote L. 2007. Congenital heart disease in the general population. Circulation 115: 163-172. doi:10.1161/CIRCULATION AHA.106.627224

Marin TM, Keith K, Davies B, Conner DA, Guha P, Kalaitzidis D, Wu X, Lauriol J, Wang B, Bauer M, et al. 2011. Rapamycin reverses hypertrophic cardiomyopathy in a mouse model of LEOPARD syndrome-associated PTPN11 mutation. J Clin Invest 121: 1026-1043. doi:10 $.1172 /$ JCI44972

Marino B, Digilio MC, Toscano A, Giannotti A, Dallapiccola B. 1999. Congenital heart diseases in children with Noonan syndrome: an expanded cardiac spectrum with high prevalence of atrioventricular canal. J Pediatr 135: 703-706. doi:10.1016/S0022-3476(99)70088-0

Marino B, Digilio MC, Toscano A, Anaclerio S, Giannotti A, Feltri C, De Ioris MA, Angioni A, Dallapiccola B. 2001. Anatomic patterns of conotruncal defects associated with deletion 22q11. Genet Med 3: 45-48. doi:10.1097/ 00125817-200101000-00010

Martinelli S, De Luca A, Stellacci E, Rossi C, Checquolo S, Lepri F, Caputo V, Silvano M, Buscherini F, Consoli F, et al. 2010. Heterozygous germline mutations in the CBL tumor-suppressor gene cause a Noonan syndrome-like phenotype. Am J Hum Genet 87: 250-257. doi:10.1016/j ajhg.2010.06.015

Matsson H, Eason J, Bookwalter CS, Klar J, Gustavsson P, Sunnegårdh J, Enell H, Jonzon A, Vikkula M, Gutierrez I, et al. 2008. Alpha-cardiac actin mutations produce atrial septal defects. Hum Mol Genet 17: 256-265. doi:10.1093/ hmg/ddm302

Mazzanti L, Cacciari E. 1998. Congenital heart disease in patients with Turner's syndrome. J Pediatr 133: 688692. doi:10.1016/S0022-3476(98)70119-2

McDaniell R, Warthen DM, Sanchez-Lara PA, Pai A, Krantz ID, Piccoli DA, Spinner NB. 2006. NOTCH2 mutations cause Alagille syndrome, a heterogeneous disorder of the notch signaling pathway. Am J Hum Genet 79: 169-173. doi:10.1086/505332

McDermott DA, Fong JC, Basson CT. 1993. Holt-Oram syndrome. University of Washington, Seattle.

McDermott DA, Bressan MC, He J, Lee JS, Aftimos S, Brueckner M, Gilbert F, Graham GE, Hannibal MC, Innis JW, et al. 2005. TBX5 genetic testing validates strict clinical criteria for Holt-Oram syndrome. Pediatr Res 58: 981-986. doi:10.1203/01.PDR.0000182593.95441.64

McElhinney DB, Clark BJ, Weinberg PM, Kenton ML, McDonald-McGinn D, Driscoll DA, Zackai EH, Goldmuntz E. 2001. Association of chromosome 22q11 deletion with isolated anomalies of aortic arch laterality and branching. J Am Coll Cardiol 37: 2114-2119. doi:10.1016/ S0735-1097(01)01286-4 
McElhinney DB, Krantz ID, Bason L, Piccoli DA, Emerick KM, Spinner NB, Goldmuntz E. 2002. Analysis of cardiovascular phenotype and genotype-phenotype correlation in individuals with a JAG1 mutation and/or Alagille syndrome. Circulation 106: 2567-2574. doi:10.1161/01.CIR .0000037221 .45902 .69

Meester JAN, Verstraeten A, Alaerts M, Schepers D, Van Laer L, Loeys BL. 2019. Overlapping but distinct roles for NOTCH receptors in human cardiovascular disease Clin Genet 95: 85-94. doi:10.1111/cge.13382

Mefford HC, Rosenfeld JA, Shur N, Slavotinek AM, Cox VA, Hennekam RC, Firth HV, Willatt L, Wheeler P, Morrow EM, et al. 2012. Further clinical and molecular delineation of the 15q24 microdeletion syndrome. J Med Genet 49: 110-118. doi:10.1136/jmedgenet-2011-100499

Merscher S, Funke B, Epstein JA, Heyer J, Puech A, Lu MM, Xavier RJ, Demay MB, Russell RG, Factor S, et al. 2001. TBX1 is responsible for cardiovascular defects in velocardio-facial/DiGeorge syndrome. Cell 104: 619-629. doi:10.1016/S0092-8674(01)00247-1

Michielon G, Marino B, Formigari R, Gargiulo G, Picchio F, Digilio MC, Anaclerio S, Oricchio G, Sanders SP, Di Donato RM. 2006. Genetic syndromes and outcome after surgical correction of tetralogy of Fallot. Ann Thorac Surg 81: 968-975. doi:10.1016/j.athoracsur.2005.09.033

Michielon G, Marino B, Oricchio G, Digilio MC, Iorio F, Filippelli S, Placidi S, Di Donato RM. 2009. Impact of DEL22q11, trisomy 21, and other genetic syndromes on surgical outcome of conotruncal heart defects. $J$ Thorac Cardiovasc Surg 138: 565-570.e2. doi:10.1016/j.jtcvs .2009 .03 .009

Miller EM, Hopkin R, Bao L, Ware SM. 2012. Implications for genotype-phenotype predictions in Townes-Brocks syndrome: case report of a novel SALL1 deletion and review of the literature. Am J Med Genet A 158: 533540. doi:10.1002/ajmg.a.34426

Mirra V, Werner C, Santamaria F. 2017. Primary ciliary dyskinesia: an update on clinical aspects, genetics, diagnosis, and future treatment strategies. Front Pediatr 5: 135. doi:10.3389/fped.2017.00135

Mitchell LE, Agopian AJ, Bhalla A, Glessner JT, Kim CE, Swartz MD, Hakonarson H, Goldmuntz E. 2015. Genome-wide association study of maternal and inherited effects on left-sided cardiac malformations. Hum Mol Genet 24: 265-273. doi:10.1093/hmg/ddu420

Mitter D, Chiaie BD, Lüdecke HJ, Gillessen-Kaesbach G, Bohring A, Kohlhase J, Caliebe A, Siebert R, Roepke A, Ramos-Arroyo MA, et al. 2010. Genotype-phenotype correlation in eight new patients with a deletion encompassing 2q31.1. Am J Med Genet Part A 152A: 1213-1224. doi:10.1002/ajmg.a.33344

Mohapatra B, Casey B, Li H, Ho-Dawson T, Smith L, Fernbach SD, Molinari L, Niesh SR, Jefferies JL, Craigen WJ, et al. 2009. Identification and functional characterization of NODAL rare variants in heterotaxy and isolated cardiovascular malformations. Hum Mol Genet 18: 861-871. doi:10.1093/hmg/ddn411

Moons P, Sluysmans T, De Wolf D, Massin M, Suys B, Benatar A, Gewillig M. 2009. Congenital heart disease in 111,225 births in Belgium: birth prevalence, treatment and survival in the 21st century. Acta Paediatr 98: 472477. doi:10.1111/j.1651-2227.2008.01152.x
Morris CA. 1993. Williams syndrome. University of Washington, Seattle.

Morris CA, Mervis CB. 2002. Williams syndrome and related disorders. Annu Rev Genomics Hum Genet 1: 461-484. doi:10.1146/annurev.genom.1.1.461

Muru K, Kalev I, Teek R, Sõnajalg M, Kuuse K, Reimand T, Ounap K. 2011. A boy with Holt-Oram syndrome caused by novel mutation c.1304delT in the TBX5 gene. Mol Syndromol 1: 307-310. doi:10.1159/000330109

Musewe NN, Alexander DJ, Teshima I, Smallhorn JF, Freedom RM. 1990. Echocardiographic evaluation of the spectrum of cardiac anomalies associated with trisomy 13 and trisomy 18. J Am Coll Cardiol 15: 673-677. doi:10.1016/0735-1097(90)90644-5

Nakajima Y, Yamagishi T, Hokari S, Nakamura H. 2000. Mechanisms involved in valvuloseptal endocardial cushion formation in early cardiogenesis: roles of transforming growth factor (TGF) $-\beta$ and bone morphogenetic protein (BMP). Anat Rec 258: 119-127. doi:10.1002/(SICI) 1097-0185(20000201)258:2<119::AID-AR1>3.0.CO;2-U

Nemani L, Barik R, Patnaik A, Mishra R, Rao A, Kapur P. 2014. Coffin-Siris syndrome with the rarest constellation of congenital cardiac defects: a case report with review of literature. Ann Pediatr Cardiol 7: 221-226. doi:10.4103/ 0974-2069.140859

Nguyen JM, Qualmann KJ, Okashah R, Reilly A, Alexeyev MF, Campbell DJ. 5p 2015. Deletions: current knowledge and future directions. Am J Med Genet C Semin Med Genet 169: 224. doi:10.1002/ajmg.c.31444.

Nielsen J, Wohlert M. 1991. Chromosome abnormalities found among 34910 newborn children: results from a 13-year incidence study in Århus, Denmark. Hum Genet 87: 81-83. doi:10.1007/BF01213097

Niessen K, Karsan A. 2008. Notch signaling in cardiac development. Circ Res 102: 1169-1181. doi:10.1161/CIRC RESAHA.108.174318

Nora JJ. 1994. From generational studies to a multilevel genetic-environmental interaction. J Am Coll Cardiol 23: 1468-1471. doi:10.1016/0735-1097(94)90393-X

Nora JJ, Nora AH, Optiz JM, Reynolds JF. 1988. Update on counseling the family with a first-degree relative with a congenital heart defect. Am J Med Genet 29: 137-142. doi:10.1002/ajmg.1320290117

Oda T, Elkahloun AG, Pike BL, Okajima K, Krantz ID, Genin A, Piccoli DA, Meltzer PS, Spinner NB, Collins FS, et al. 1997. Mutations in the human Jagged1 gene are responsible for Alagille syndrome. Nat Genet 16: 235-242. doi:10.1038/ng0797-235

O'Connor MJ, Tang X, Collins RT. 2015. Cardiac diagnoses, procedures, and healthcare utilisation in inpatients with Ellis-van Creveld syndrome. Cardiol Young 25: 95-101. doi:10.1017/S1047951113001819

Olson EN. 2006. Gene regulatory networks in the evolution and development of the heart. Science 313: 1922-1927. doi:10.1126/science.1132292

Oster MME, Lee KA, Honein MA, Riehle-Colarusso TT, Shin M, Correa A, Reller M, Strickland M, Riehle-Colarusso TT, Mahle W, et al. 2013. Temporal trends in survival among infants with critical congenital heart defects. Pediatrics 131: e1502-e1508. doi:10.1542/peds.2012-3435 
S.N. Nees and W.K. Chung

Øyen N, Poulsen G, Boyd HA, Wohlfahrt J, Jensen PKA, Melbye M. 2009. Recurrence of congenital heart defects in families. Circulation 120: 295-301. doi:10.1161/CIR CULATIONAHA.109.857987

Oyen N, Poulsen G, Wohlfahrt J, Boyd HA, Jensen PKA, Melbye M. 2010. Recurrence of discordant congenital heart defects in families. Circ Cardiovasc Genet 3: 122128. doi:10.1161/CIRCGENETICS.109.890103

Page DJ, Miossec MJ, Williams SG, Monaghan RM, Fotiou E, Cordell HJ, Sutcliffe L, Topf A, Bourgey M, Bourque G et al. 2019. Whole exome sequencing reveals the major genetic contributors to nonsyndromic tetralogy of Fallot. Circ Res 124: 553-563. doi:10.1161/CIRCRESAHA.118 .313250

Pandit B, Sarkozy A, Pennacchio LA, Carta C, Oishi K, Martinelli S, Pogna EA, Schackwitz W, Ustaszewska A, Landstrom A, et al. 2007. Gain-of-function RAF1 mutations cause Noonan and LEOPARD syndromes with hypertrophic cardiomyopathy. Nat Genet 39: 1007-1012. doi:10.1038/ng2073

Patel A, Costello JM, Backer CL, Pasquali SK, Hill KD, Wallace AS, Jacobs JP, Jacobs ML. 2016. Prevalence of noncardiac and genetic abnormalities in neonates undergoing cardiac operations: analysis of The Society of Thoracic Surgeons Congenital Heart Surgery Database. Ann Thorac Surg 102: 1607-1614. doi:10.1016/j.athoracsur .2016 .04 .008

Paulussen ADC, Steyls A, Vanoevelen J, van Tienen FH, Krapels IPC, Claes GR, Chocron S, Velter C, Tan-Sindhunata GM, Lundin C, et al. 2016. Rare novel variants in the ZIC3 gene cause X-linked heterotaxy. Eur J Hum Genet 24: 1783-1791. doi:10.1038/ejhg.2016.91

Perera JL, Johnson NM, Judge DP, Crosson JE. 2014. Novel and highly lethal NKX2.5 missense mutation in a family with sudden death and ventricular arrhythmia. Pediatr Cardiol 35: 1206-1212. doi:10.1007/s00246-014-0917-3

Peyvandi S, Lupo PJ, Garbarini J, Woyciechowski S, Edman S, Emanuel BS, Mitchell LE, Goldmuntz E. 2013a. 22q11.2 deletions in patients with conotruncal defects: data from 1,610 consecutive cases. Pediatr Cardiol 34: 1687-1694. doi:10.1007/s00246-013-0694-4

Peyvandi F, Kunicki T, Lillicrap D. 2013b. Genetic sequence analysis of inherited bleeding diseases. Blood 14: 34233431. doi:10.1182/blood-2013-05-505511

Phelan K, McDermid HE. 2012. The 22q13.3 deletion syndrome (Phelan-McDermid syndrome). Mol Syndromol 2: $186-201$.

Pierpont ME, Basson CT, Benson DW, Gelb BD, Giglia TM, Goldmuntz E, McGee G, Sable CA, Srivastava D, Webb CL. 2007. Genetic basis for congenital heart defects: current knowledge a scientific statement from the American Heart Association Congenital Cardiac Defects Committee, Council on Cardiovascular Disease in the Young: endorsed by the American Academy of Pediatrics. Circulation 115: 3015-3038. doi:10.1161/CIRCULATION AHA.106.183056

Pierpont MEM, Magoulas PL, Adi S, Kavamura MI, Neri G, Noonan J, Pierpont EI, Reinker K, Roberts AE, Shankar S, et al. 2014. Cardio-facio-cutaneous syndrome: clinical features, diagnosis, and management guidelines. Pediatrics 134: e1149-e1162. doi:10.1542/peds.2013-3189
Pierpont ME, Brueckner M, Chung WK, Garg V, Lacro RV, McGuire AL, Mital S, Priest JR, Pu WT, Roberts A, et al. 2018. Genetic basis for congenital heart disease: revisited: a scientific statement from the American Heart Association. Circulation 138: e653-e711. doi:10.1161/CIR .0000000000000606

Portnoï MF. 2009. Microduplication 22q11.2: a new chromosomal syndrome. Eur J Med Genet 52: 88-93. doi:10 $.1016 /$ j.ejmg.2009.02.008

Posch MG, Waldmuller S, Müller M, Scheffold T, Fournier D, Andrade-Navarro MA, De Geeter B, Guillaumont S, Dauphin C, Yousseff D, et al. 2011. Cardiac $\alpha$-myosin (MYH6) is the predominant sarcomeric disease gene for familial atrial septal defects. PLoS ONE 6: e28872. doi:10 .1371/journal.pone.0028872

Postma AV, van Engelen K, van de Meerakker J, Rahman T, Probst S, Baars MJH, Bauer U, Pickardt T, Sperling SR, Berger F, et al. 2011. Mutations in the sarcomere gene MYH7 in Ebstein anomaly. Circ Cardiovasc Genet 4: 43-50. doi:10.1161/CIRCGENETICS.110.957985

Preuss C, Capredon M, Wünnemann F, Chetaille P, Prince A, Godard B, Leclerc S, Sobreira N, Ling H, Awadalla P, et al. 2016. Family based whole exome sequencing reveals the multifaceted role of Notch signaling in congenital heart disease. PLoS Genet 12: e1006335. doi:10.1371/jour nal.pgen.1006335

Qian Y, Xiao D, Guo X, Chen H, Hao L, Ma X, Huang G, Ma D, Wang H. 2017. Multiple gene variations contributed to congenital heart disease via GATA family transcriptional regulation. J Transl Med 15: 69. doi:10.1186/s12967-0171173-0

Qiao X-H, Wang Q, Wang J, Liu X-Y, Xu Y-J, Huang R-T, Xue S, Li Y-J, Zhang M, Qu X-K, et al. 2018. A novel NR2F2 loss-of-function mutation predisposes to congenital heart defect. Eur J Med Genet 61: 197-203. doi:10 .1016/j.ejmg.2017.12.003

Quiros-Tejeira RE, Ament ME, Heyman MB, Martin MG, Rosenthal P, Hall TR, McDiarmid S V, Vargas JH. 1999. Variable morbidity in alagille syndrome: a review of 43 cases. J Pediatr Gastroenterol Nutr 29: 431-437. doi:10 .1097/00005176-199910000-00011

Rajagopal SK, Ma Q, Obler D, Shen J, Manichaikul A, Tomita-Mitchell A, Boardman K, Briggs C, Garg V, Srivastava D, et al. 2007. Spectrum of heart disease associated with murine and human GATA4 mutation. J Mol Cell Cardiol 43: 677-685. doi:10.1016/j.yjmcc.2007.06.004

Rajagopalan R, Grochowski CM, Gilbert MA, Falsey AM, Coleman K, Romero R, Loomes KM, Piccoli DA, Devoto M, Spinner NB. 2016. Compound heterozygous mutations in NEK8 in siblings with end-stage renal disease with hepatic and cardiac anomalies. Am J Med Genet A 170: 750-753. doi:10.1002/ajmg.a.37512

Rasmussen SA, Wong LYC, Yang Q, May KM, Friedman JM. 2003. Population-based analyses of mortality in trisomy 13 and trisomy 18. Pediatrics 111: 777-784. doi:10.1542/ peds.111.4.777

Rauen KA, Banerjee A, Bishop WR, Lauchle JO, McCormick F, McMahon M, Melese T, Munster PN, Nadaf S, Packer RJ, et al. 2011. Costello and cardio-facio-cutaneous syndromes: moving toward clinical trials in RASopathies. Am $J$ Med Genet Part C Semin Med Genet 157: 136-146. doi:10.1002/ajmg.c.30294 
Reamon-Buettner SM, Ciribilli Y, Inga A, Borlak J. 2008. A loss-of-function mutation in the binding domain of HAND1 predicts hypoplasia of the human hearts. Hum Mol Genet 17: 1397-1405. doi:10.1093/hmg/ddn027

Reamon-Buettner SM, Ciribilli Y, Traverso I, Kuhls B, Inga A, Borlak J. 2009. A functional genetic study identifies HAND1 mutations in septation defects of the human heart. Hum Mol Genet 18: 3567-3578. doi:10.1093/ hmg/ddp305

Redon R, Ishikawa S, Fitch KR, Feuk L, Perry GH, Andrews TD, Fiegler H, Shapero MH, Carson AR, Chen W, et al. 2006. Global variation in copy number in the human genome. Nature 444: 444-454. doi:10.1038/nature05329

Reller MD, Morris CD. 1998. Is Down syndrome a risk factor for poor outcome after repair of congenital heart defects? J Pediatr 132: 738-741. doi:10.1016/S0022-3476(98) 70372-5

Retterer K, Juusola J, Cho MT, Vitazka P, Millan F, Gibellini F, Vertino-Bell A, Smaoui N, Neidich J, Monaghan KG, et al. 2016. Clinical application of whole-exome sequencing across clinical indications. Genet Med 18: 696-704. doi:10 .1038 /gim.2015.148

Roberts AE, Araki T, Swanson KD, Montgomery KT, Schiripo TA, Joshi VA, Li L, Yassin Y, Tamburino AM, Neel BG, et al. 2007. Germline gain-of-function mutations in SOS1 cause Noonan syndrome. Nat Genet 39: 70-74. doi: $10.1038 / \mathrm{ng} 1926$

Roberts AE, Allanson JE, Tartaglia M, Gelb BD. 2013. Noonan syndrome. Lancet 381: 333-342. doi:10.1016/ S0140-6736(12)61023-X

Roessler E, Ouspenskaia M V, Karkera JD, Vélez JI, Kantipong A, Lacbawan F, Bowers P, Belmont JW, Towbin JA, Goldmuntz E, et al. 2008. Reduced NODAL signaling strength via mutation of several pathway members including FOXH1 is linked to human heart defects and holoprosencephaly. Am J Hum Genet 83: 18-29. doi:10 .1016/j.ajhg.2008.05.012

Romano AA, Allanson JE, Dahlgren J, Gelb BD, Hall B, Pierpont ME, Roberts AE, Robinson W, Takemoto CM Noonan JA. 2010. Noonan syndrome: clinical features, diagnosis, and management guidelines. Pediatrics 126: 746-759. doi:10.1542/peds.2009-3207

Rosenfeld JA, Lacassie Y, El-Khechen D, Escobar LF, Reggin J, Heuer C, Chen E, Jenkins LS, Collins AT, Zinner S, et al. 2011. New cases and refinement of the critical region in the 1q41q42 microdeletion syndrome. Eur J Med Genet 54: 42-49. doi:10.1016/j.ejmg.2010.10.002

Ruiz-Perez VL, Ide SE, Strom TM, Lorenz B, Wilson D, Woods K, King L, Francomano C, Freisinger P, Spranger S, et al. 2000. Mutations in a new gene in Ellis-van Creveld syndrome and Weyers acrodental dysostosis. Nat Genet 24: 283-286. doi: $10.1038 / 73508$

Ruiz-Perez VL, Tompson SWJ, Blair HJ, Espinoza-Valdez C, Lapunzina P, Silva EO, Hamel B, Gibbs JL, Young ID, Wright MJ, et al. 2003. Mutations in two nonhomologous genes in a head-to-head configuration cause Ellis-van Creveld syndrome. Am J Hum Genet 72: 728-732. doi: $10.1086 / 368063$

Salonen R, Paavola P. 1998. Meckel syndrome. J Med Genet 35: 497-501. doi:10.1136/jmg.35.6.497

Sampayo F, Pinto FF. 1994. The sex distribution of congenital cardiopathies. Acta Med Port 7: 413-418.
Satoda M, Pierpont MEM, Diaz GA, Gelb BD. 1999. Char syndrome, an inherited disorder with patent ductus arteriosus, maps to chromosome 6p12-p21. Circulation 99: 3036-3042.

Satoda M, Zhao F, Diaz GA, Burn J, Goodship J, Davidson HR, Pierpont MEM, Gelb BD. 2000. Mutations in TFAP2B cause Char syndrome, a familial form of patent ductus arteriosus. Nat Genet 25: 42-46. doi:10.1038/ 75578

Schott JJ, Benson DW, Basson CT, Pease W, Silberbach GM, Moak JP, Maron BJ, Seidman CE, Seidman JG. 1998. Congenital heart disease caused by mutations in the transcription factor NKX2-5. Science 281: 108-111. doi:10 $.1126 /$ science.281.5373.108

Scurr I, Wilson L, Lees M, Robertson S, Kirk E, Turner A, Morton J, Kidd A, Shashi V, Stanley C, et al. 2011. Cantú syndrome: report of nine new cases and expansion of the clinical phenotype. Am J Med Genet A 155: 508-518. doi:10.1002/ajmg.a.33885

Selicorni A, Colli AM, Passarini A, Milani D, Cereda A, Cerutti M, Maitz S, Alloni V, Salvini L, Galli MA, et al. 2009. Analysis of congenital heart defects in 87 consecutive patients with Brachmann-de Lange syndrome. Am J Med Genet A 149: 1268-1272. doi:10.1002/ajmg.a.32838

Shan J-P, Wang X-L, Qiao Y-G, Wan Yan HX, Huang WH, Pang SC, Yan B. 2014. Novel and functional DNA sequence variants within the GATA5 gene promoter in ventricular septal defects. World J Pediatr 10: 348-353. doi:10 .1007/s12519-014-0511-z

Shen L, Li X-F, Shen A-D, Wang Q, Liu CX, Guo YJ, Song ZJ, Li ZZ. 2010. Transcription factor HAND2 mutations in sporadic Chinese patients with congenital heart disease. Chin Med J (Engl) 123: 1623-1627.

Shuib S, McMullan D, Rattenberry E, Barber RM, Rahman F, Zatyka M, Chapman C, Macdonald F, Latif F, Davison V, et al. 2009. Microarray based analysis of 3p25-p26 deletions (3p- syndrome). Am J Med Genet Part A 149A: 2099-2105. doi:10.1002/ajmg.a.32824

Sifrim A, Hitz MP, Wilsdon A, Breckpot J, Al Turki SH, Thienpont B, McRae J, Fitzgerald TW, Singh T, Swaminathan GJ, et al. 2016. Distinct genetic architectures for syndromic and nonsyndromic congenital heart defects identified by exome sequencing. Nat Genet 48: 10601065. doi:10.1038/ng.3627

Sletten LJ, Pierpont MEM. 1996. Variation in severity of cardiac disease in Holt-Oram syndrome. Am J Med Genet 65: 128-132. doi:10.1002/(SICI)1096-8628(19961016)65 $: 2<128::$ AID-AJMG9>3.0.CO;2-O

Smemo S, Campos LC, Moskowitz IP, Krieger JE, Pereira AC, Nobrega MA. 2012. Regulatory variation in a TBX5 enhancer leads to isolated congenital heart disease. Hum Mol Genet 21: 3255-3263. doi:10.1093/hmg/dds165

Soemedi R, Wilson IJ, Bentham J, Darlay R, Töpf A, Zelenika D, Cosgrove C, Setchfield K, Thornborough C, GranadosRiveron J, et al. 2012. Contribution of global rare copynumber variants to the risk of sporadic congenital heart disease. Am J Hum Genet 91: 489-501. doi:10.1016/j.ajhg .2012 .08 .003

Southard AE, Edelmann LJ, Gelb BD, Redon R, Ishikawa S, Fitch K, Conrad D, Pinto D, Redon R, Park H, et al. 2012. Role of copy number variants in structural birth defects. Pediatrics 129: 755-763. doi:10.1542/peds.2011-2337 
Sperling S, Grimm CH, Dunkel I, Mebus S, Sperling HP Ebner A, Galli R, Lehrach H, Fusch C, Berger F, et al. 2005. Identification and functional analysis of CITED2 mutations in patients with congenital heart defects. Hum Mutat 26: 575-582. doi:10.1002/humu.20262

Spinner NB, Leonard LD, Krantz ID. 1993. Alagille syndrome. In GeneReviews. University of Washington, Seattle.

Springett A, Wellesley D, Greenlees R, Loane M, Addor MC Arriola L, Bergman J, Cavero-Carbonell C, Csaky-Szunyogh M, Draper ES, et al. 2015. Congenital anomalies associated with trisomy 18 or trisomy 13: a registry-based study in 16 European countries, 2000-2011. Am J Med Genet Part A 167: 3062-3069. doi:10.1002/ajmg.a.37355

Stallmeyer B, Fenge H, Nowak-Göttl U, Schulze-Bahr E. 2010. Mutational spectrum in the cardiac transcription factor gene NKX2.5 (CSX) associated with congenital heart disease. Clin Genet 78: 533-540. doi:10.1111/j .1399-0004.2010.01422.x

Steimle JD, Moskowitz IP. 2017. TBX5: a key regulator of heart development. Curr Top Dev Biol 122: 195-221. doi:10.1016/bs.ctdb.2016.08.008

Stevens CA, Bhakta MG. 1995. Cardiac abnormalities in the Rubinstein-Taybi syndrome. Am J Med Genet 59: $346-$ 348. doi:10.1002/ajmg.1320590313

St Louis JD, Jodhka U, Jacobs JP, He X, Hill KD, Pasquali SK, Jacobs ML. 2014. Contemporary outcomes of complete atrioventricular septal defect repair: analysis of the Society of Thoracic Surgeons Congenital Heart Surgery Database. $J$ Thorac Cardiovasc Surg 148: 2526-2531. doi:10.1016/j .jtcvs.2014.05.095

Stittrich A-B, Lehman A, Bodian DL, Ashworth J, Zong Z, Li H, Lam P, Khromykh A, Iyer RK, Vockley JG, et al. 2014. Mutations in NOTCH1 cause Adams-Oliver syndrome. Am J Hum Genet 95: 275-284. doi:10.1016/j.ajhg.2014.07 .011

Sun X, Meng Y, You T, Li P, Wu H, Yu M, Xie X. 2013. Association of growth/differentiation factor 1 gene polymorphisms with the risk of congenital heart disease in the Chinese Han population. Mol Biol Rep 40: 1291-1299. doi:10.1007/s11033-012-2172-0

Sun Y-M, Wang J, Qiu X-B, Yuan F, Li R-G, Xu Y-J, Qu X-K, Shi H-Y, Hou X-M, Huang R-T, et al. 2016. A HAND2 loss-of-function mutation causes familial ventricular septal defect and pulmonary stenosis. G3 (Bethesda) 6: 987992. doi:10.1534/g3.115.026518

Suspitsin EN, Imyanitov EN. 2016. Bardet-Biedl syndrome. Mol Syndromol 7: 62-71. doi:10.1159/000445491

Sutherland MJ, Ware SM. 2009. Disorders of left-right asymmetry: heterotaxy and situs inversus. Am J Med Genet Part C Semin Med Genet 151C: 307-317. doi:10.1002/ ajmg.c. 30228

Swinkels MEM, Simons A, Smeets DF, Vissers LE, Veltman JA, Pfundt R, de Vries BB, Faas BH, Schrander-Stumpel CT, McCann E, et al. 2008. Clinical and cytogenetic characterization of 13 Dutch patients with deletion 9p syndrome: delineation of the critical region for a consensus phenotype. Am J Med Genet Part A 146A: 1430-1438. doi:10.1002/ajmg.a.32310

Sybert VP, McCauley E. 2004. Turner's syndrome. N Engl J Med 351: 1227-1238. doi:10.1056/NEJMra030360
Tartaglia M, Mehler EL, Goldberg R, Zampino G, Brunner HG, Kremer H, van der Burgt I, Crosby AH, Ion A, Jeffery S, et al. 2001. Mutations in PTPN11, encoding the protein tyrosine phosphatase SHP-2, cause Noonan syndrome. Nat Genet 29: 465-468. doi:10.1038/ng772

Tartaglia M, Kalidas K, Shaw A, Song X, Musat DL, van der Burgt I, Brunner HG, Bertola DR, Crosby A, Ion A, et al. 2002. PTPN11 mutations in Noonan syndrome: molecular spectrum, genotype-phenotype correlation, and phenotypic heterogeneity. Am J Hum Genet 70: 1555-1563. doi:10.1086/340847

Tartaglia M, Gelb BD, Zenker M. 2011. Noonan syndrome and clinically related disorders. Best Pract Res Clin Endocrinol Metab 25: 161-179. doi:10.1016/j.beem.2010.09 .002 .

Thacoor A. 2017. Mitral valve prolapse and Marfan syndrome. Congenit Heart Dis 12: 430-434. doi:10.1111/ chd. 12467

Tham E, Lindstrand A, Santani A, Malmgren H, Nesbitt A, Dubbs HA, Zackai EH, Parker MJ, Millan F, Rosenbaum $\mathrm{K}$, et al. 2015. Dominant mutations in KAT6A cause intellectual disability with recognizable syndromic features. Am J Hum Genet 96: 507-513. doi:10.1016/j.ajhg.2015.01 .016

The Clinical Genome Resource Gene Curation Working Group. 2018. Gene clinical validity curation process: standard operating procedure. https://clinicalgenome.org/site/ assets/files/2165/gene_curation_sop_version_6_aug_2018_ final.pdf

Theis JL, Zimmermann MT, Evans JM, Eckloff BW, Wieben ED, Qureshi MY, O'Leary PW, Olson TM. 2015. Recessive MYH6 mutations in hypoplastic left heart with reduced ejection fraction. Circ Cardiovasc Genet 8: 564-571. doi:10.1161/CIRCGENETICS.115.001070

Thienpont B, Mertens L, de Ravel T, Eyskens B, Boshoff D, Maas N, Fryns JP, Gewillig M, Vermeesch JR, Devriendt K. 2007. Submicroscopic chromosomal imbalances detected by array-CGH are a frequent cause of congenital heart defects in selected patients. Eur Heart J 28: 27782784. doi:10.1093/eurheartj/ehl560

Thienpont B, Zhang L, Postma AV, Breckpot J, Tranchevent L-C, Van Loo P, Møllgård K, Tommerup N, Bache I, Tümer Z, et al. 2010. Haploinsufficiency of TAB2 causes congenital heart defects in humans. Am J Hum Genet 86: 839-849. doi:10.1016/j.ajhg.2010.04.011

Thorsson T, Russell WW, El-Kashlan N, Soemedi R, Levine J, Geisler SB, Ackley T, Tomita-Mitchell A, Rosenfeld JA, Töpf A, et al. 2015. Chromosomal imbalances in patients with congenital cardiac defects: a meta-analysis reveals novel potential critical regions involved in heart development. Congenit Heart Dis 10: 193-208. doi:10.1111/chd .12179

Tory K, Rousset-Rouvière C, Gubler M-C, Morinière V, Pawtowski A, Becker C, Guyot C, Gié S, Frishberg Y, Nivet $\mathrm{H}$, et al. 2009. Mutations of NPHP2 and NPHP3 in infantile nephronophthisis. Kidney Int 75: 839-847. doi:10 $.1038 / \mathrm{ki} .2008 .662$

Töpf A, Griffin HR, Glen E, Soemedi R, Brown DL, Hall D, Rahman TJ, Eloranta JJ, Jüngst C, Stuart AG, et al. 2014. Functionally significant, rare transcription factor variants in tetralogy of Fallot. PLoS ONE 9: e95453. doi:10.1371/ journal.pone.0095453 
Trider C-L, Arra-Robar A, van Ravenswaaij-Arts C, Blake K. 2017. Developing a CHARGE syndrome checklist: health supervision across the lifespan (from head to toe). Am J Med Genet A 173: 684-691. doi:10.1002/ajmg.a.38085

Tumanyan MR, Filaretova OV, Chechneva VV, Gulasaryan RS, Butrim IV, Bockeria LA. 2015. Repair of complete atrioventricular septal defect in infants with Down syndrome: outcomes and long-term results. Pediatr Cardiol 36: 71-75. doi:10.1007/s00246-014-0966-7

Turnpenny PD, Ellard S. 2012. Alagille syndrome: pathogenesis, diagnosis and management. Eur J Hum Genet 20: 251-257. doi:10.1038/ejhg.2011.181

Tutar E, Ekici F, Atalay S, Nacar N. 2005. The prevalence of bicuspid aortic valve in newborns by echocardiographic screening. Am Heart J 150: 513-515. doi:10.1016/j.ahj .2004 .10 .036

Van Den Berg DJ, Francke U. 1993. Roberts syndrome: a review of 100 cases and a new rating system for severity. Am J Med Genet 47: 1104-1123. doi:10.1002/ajmg .1320470735

van der Linde D, Konings EEM, Slager MA, Witsenburg M, Helbing WA, Takkenberg JJM, Roos-Hesselink JW. 2011. Birth prevalence of congenital heart disease worldwide: a systematic review and meta-analysis. J Am Coll Cardiol 58: 2241-2247. doi:10.1016/j.jacc.2011.08.025

Van Maldergem L, Siitonen HA, Jalkh N, Chouery E, De Roy M, Delague V, Muenke M, Jabs EW, Cai J, Wang LL, et al. 2006. Revisiting the craniosynostosis-radial ray hypoplasia association: Baller-Gerold syndrome caused by mutations in the RECQL4 gene. J Med Genet 43: 148-152. doi:10.1136/jmg.2005.031781

Van Praagh S, Truman T, Firpo A, Bang-Rodrigo A, Fried R, McManus B, Engle MA, Van Praagh R. 1989. Cardiac malformations in trisomy-18: a study of 41 postmortem cases. J Am Coll Cardiol 13: 1586-1597. doi:10.1016/ 0735-1097(89)90353-7

Verheije R, Kupchik GS, Isidor B, Kroes HY, Lynch SA, Hawkes L, Hempel M, Gelb BD, Ghoumid J, D’Amours $\mathrm{G}$, et al. 2019. Heterozygous loss-of-function variants of MEIS2 cause a triad of palatal defects, congenital heart defects, and intellectual disability. Eur J Hum Genet 27: 278-290. doi:10.1038/s41431-018-0281-5

Versacci P, Pugnaloni F, Digilio MC, Putotto C, Unolt M, Calcagni G, Baban A, Marino B. 2018. Some isolated cardiac malformations can be related to laterality defects. J Cardiovasc Dev Dis 5: 24. doi:10.3390/jcdd5020024

Vissers LELM, van Ravenswaaij CMA, Admiraal R, Hurst JA, de Vries BBA, Janssen IM, van der Vliet WA, Huys EHLPG, de Jong PJ, Hamel BCJ, et al. 2004. Mutations in a new member of the chromodomain gene family cause CHARGE syndrome. Nat Genet 36: 955-957. doi:10 $.1038 / \mathrm{ng} 1407$

Waterham HR, Hennekam RCM. 2012. Mutational spectrum of Smith-Lemli-Opitz syndrome. Am J Med Genet C Semin Med Genet 160: 263-284. doi:10.1002/ajmg.c .31346

Wapner RJ, Babiarz JE, Levy B, Stosic M, Zimmermann B, Sigurjonsson S, Wayham N, Ryan A, Banjevic M, Lacroute $\mathrm{P}$, et al. 2015. Expanding the scope of noninvasive prenatal testing: detection of fetal microdeletion syndromes. Am J Obstet Gynecol 212: 332.e1-332.e9. doi:10 .1016/j.ajog.2014.11.041
Warthen D, Moore E, Kamath B, Morrissette J, Sanchez P, Piccoli D, Krantz I, Spinner N. 2006. Jagged1 (JAG1) mutations in Alagille syndrome: increasing the mutation detection rate. Hum Mutat 27: 436-443. doi:10.1002/humu .20310

Wat MJ, Shchelochkov OA, Holder AM, et al. 2009. Chromosome 8p23.1 deletions as a cause of complex congenital heart defects and diaphragmatic hernia. Am J Med Genet A 149A: 1661. doi:10.1002/ajmg.a.32896

Wei D, Bao H, Zhou N, Zheng GF, Liu XY, Yang YQ. 2013. GATA5 loss-of-function mutation responsible for the congenital ventriculoseptal defect. Pediatr Cardiol 34: 504-511. doi:10.1007/s00246-012-0482-6

Weiss K, Terhal PA, Cohen L, Bruccoleri M, Irving M, Martinez AF, Rosenfeld JA, Machol K, Yang Y, Liu P, et al. 2016. De novo mutations in CHD4, an ATP-dependent chromatin remodeler gene, cause an intellectual disability syndrome with distinctive dysmorphisms. Am J Hum Genet 99: 934-941. doi:10.1016/j.ajhg.2016.08.001

Wells QS, Ausborn NL, Funke BH, Pfotenhauer JP, Fredi JL, Baxter S, Disalvo TD, Hong CC. 2011. Familial dilated cardiomyopathy associated with congenital defects in the setting of a novel VCL mutation (Lys815Arg) in conjunction with a known $M Y P B C 3$ variant. Cardiogenetics 1: 10. doi:10.4081/cardiogenetics.2011.e10

Wessels MW, Brooks AS, Hoogeboom J, Niermeijer MF, Willems PJ. 2001. Kabuki syndrome: a review study of three hundred patients. Clin Dysmorphol 11: 95-102.

Wessels MW, Herkert JC, Frohn-Mulder IM, Dalinghaus M, van den Wijngaard A, de Krijger RR, Michels M, de Coo IFM, Hoedemaekers YM, Dooijes D. 2015. Compound heterozygous or homozygous truncating $M Y B P C 3$ mutations cause lethal cardiomyopathy with features of noncompaction and septal defects. Eur J Hum Genet 23: 922928. doi:10.1038/ejhg.2014.211

Wilkinson JD, Lowe AM, Salbert BA, Sleeper LA, Colan SD, Cox GF, Towbin JA, Connuck DM, Messere JE, Lipshultz SE. 2012. Outcomes in children with Noonan syndrome and hypertrophic cardiomyopathy: a study from the Pediatric Cardiomyopathy Registry. Am Heart J 164: $442-$ 448. doi:10.1016/j.ahj.2012.04.018

Wren C, Oslizlok P, Bull C. 1990. Natural history of supravalvular aortic stenosis and pulmonary artery stenosis. $J$ Am Coll Cardiol 15: 1625-1630. doi:10.1016/0735-1097 (90)92837-R

Wu X, Simpson J, Hong JH, Kim KH, Thavarajah NK, Backx PH, Neel BG, Araki T. 2011. MEK-ERK pathway modulation ameliorates disease phenotypes in a mouse model of Noonan syndrome associated with the Raf1L613 V mutation. J Clin Invest 121: 1009-1025. doi:10.1172/ JCI44929

Wyllie JP, Wright MJ, Burn J, Hunter S. 1994. Natural history of trisomy 13. Arch Dis Child 71: 343-345. doi:10 $.1136 /$ adc.71.4.343

Xu Y-J, Di R-M, Qiao Q, Li X-M, Huang R-T, Xue S, Liu X-Y, Wang J, Yang Y-Q. 2018. GATA6 loss-of-function mutation contributes to congenital bicuspid aortic valve. Gene 663: 115-120. doi:10.1016/j.gene.2018.04.018

Xu W, Ahmad A, Dagenais S, Iyer RK, Innis JW. 2012. Chromosome 4q deletion syndrome: narrowing the cardiovascular critical region to $4 \mathrm{q} 32.2-\mathrm{q} 34.3$. Am J Med Genet Part A 158A: 635-640. doi:10.1002/ajmg.a.34425 
S.N. Nees and W.K. Chung

Yagi H, Furutani Y, Hamada H, Sasaki T, Asakawa S, Minoshima S, Ichida F, Joo K, Kimura M, Imamura S, et al. 2003. Role of TBX1 in human del22q11.2 syndrome. Lancet 362: 1366-1373. doi:10.1016/S0140-6736(03)14632-6

Yates AR, Hoffman TM, Shepherd E, Boettner B, McBride KL. 2011. Pediatric sub-specialist controversies in the treatment of congenital heart disease in trisomy 13 or 18. J Genet Couns 20: 495-509. doi:10.1007/s10897011-9373-x

Yoshiba S, Hamada H. 2014. Roles of cilia, fluid flow, and $\mathrm{Ca}^{2+}$ signaling in breaking of left-right symmetry. Trends Genet 30: 10-17. doi:10.1016/j.tig.2013.09.001

Yuan SM. 2018. Pulmonary artery hypertension in childhood: the transforming growth factor- $\beta$ superfamily-related genes. Pediatr Neonatol 59: 112-119. doi:10.1016/j .pedneo.2016.12.008

Zaidi S, Choi M, Wakimoto H, Ma L, Jiang J, Overton JD, Romano-Adesman A, Bjornson RD, Breitbart RE, Brown $\mathrm{KK}$, et al. 2013. De novo mutations in histone-modifying genes in congenital heart disease. Nature 498: 220-223. doi:10.1038/nature12141

Zhang Y, Ai F, Zheng J, Peng B. 2017. Associations of GATA4 genetic mutations with the risk of congenital heart disease: a meta-analysis. Medicine (Baltimore) 96: e6857. doi:10.1097/MD.0000000000006857

Zhang E, Hong N, Chen S, Fu Q, Li F, Yu Y, Sun K. 2018. Targeted sequencing identifies novel GATA6 variants in a large cohort of patients with conotruncal heart defects. Gene 641: 341-348. doi:10.1016/j.gene.2017.10.083

Zhu X, Li J, Ru T, Wang Y, Xu Y, Yang Y, Wu X, Cram DS, $\mathrm{Hu}$ Y. 2016. Identification of copy number variations associated with congenital heart disease by chromosomal microarray analysis and next-generation sequencing. Prenat Diagn 36: 321-327. doi:10.1002/pd.4782

Zhu N, Welch CL, Wang J, Allen PM, Gonzaga-Jauregui C, Ma L, King AK, Krishnan U, Rosenzweig EB, Ivy DD, et al. 2018. Rare variants in SOX17 are associated with pulmonary arterial hypertension with congenital heart disease. Genome Med 10: 56. doi:10.1186/s13073-0180566-x

Ziesenitz VC, Loukanov T, Gläser C, Gorenflo M. 2016. Variable expression of Alagille syndrome in a family with a new JAG1 gene mutation. Cardiol Young 26: 164-167. doi:10.1017/S1047951114002753

Zorn AM, Barish GD, Williams BO, Lavender P, Klymkowsky MW, Varmus HE. 1999. Regulation of Wnt signaling by Sox proteins: XSox $17 \alpha / \beta$ and XSox3 physically interact with $\beta$-catenin. Mol Cell 4: 487-498. doi:10.1016/ S1097-2765(00)80200-2

Zweier C, Thiel CT, Dufke A, Crow YJ, Meinecke P, Suri M, Ala-Mello S, Beemer F, Bernasconi S, Bianchi P, et al. 2005. Clinical and mutational spectrum of Mowat-Wilson syndrome. Eur J Med Genet 48: 97-111. doi:10.1016/J .EJMG.2005.01.003 


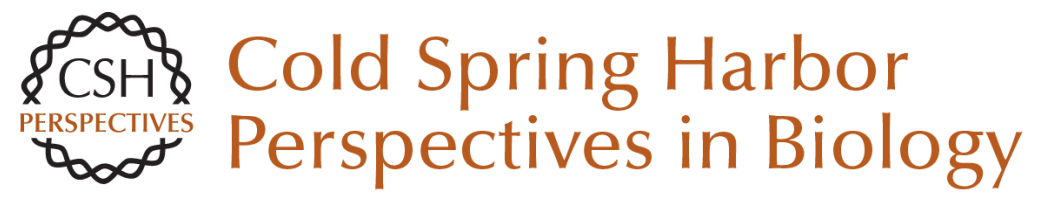

\section{Genetic Basis of Human Congenital Heart Disease}

Shannon N. Nees and Wendy K. Chung

Cold Spring Harb Perspect Biol 2020; doi: 10.1101/cshperspect.a036749 originally published online December 9, 2019

\section{Subject Collection Heart Development and Disease}

Epicardium in Heart Development

Yingxi Cao, Sierra Duca and Jingli Cao

Cardiac Neural Crest

Hiroyuki Yamagishi

The Endocardium and Heart Valves Bailey Dye and Joy Lincoln

Long Noncoding RNAs in Cardiac Development Michael Alexanian and Samir Ounzain

Genetic Basis of Human Congenital Heart Disease Shannon N. Nees and Wendy K. Chung

Cardiopharyngeal Progenitor Specification:

Multiple Roads to the Heart and Head Muscles Benjamin Swedlund and Fabienne Lescroart

Genetic and Epigenetic Control of Heart Development

Brynn N. Akerberg and William T. Pu

Formation and Growth of Cardiac Lymphatics during Embryonic Development, Heart Regeneration, and Disease

Dana Gancz, Gal Perlmoter and Karina Yaniv
In Vivo and In Vitro Genetic Models of Congenital Heart Disease

Uddalak Majumdar, Jun Yasuhara and Vidu Garg

Development of the Cardiac Conduction System

Samadrita Bhattacharyya and Nikhil V. Munshi

3D Anatomy of the Developing Heart:

Understanding Ventricular Septation

Timothy J. Mohun and Robert H. Anderson

Cardiac Morphogenesis: Specification of the

Four-Chambered Heart

Vincent Christoffels and Bjarke Jensen

The Chicken as a Model Organism to Study Heart

Development

Johannes G. Wittig and Andrea Münsterberg

The First Heartbeat--Origin of Cardiac Contractile

Activity

Richard C.V. Tyser and Shankar Srinivas

Xenopus: Experimental Access to Cardiovascular

Development, Regeneration Discovery, and

Cardiovascular Heart-Defect Modeling Stefan Hoppler and Frank L. Conlon

Reptiles as a Model System to Study Heart

Development

Bjarke Jensen and Vincent M. Christoffels

For additional articles in this collection, see http://cshperspectives.cshlp.org/cgi/collection/

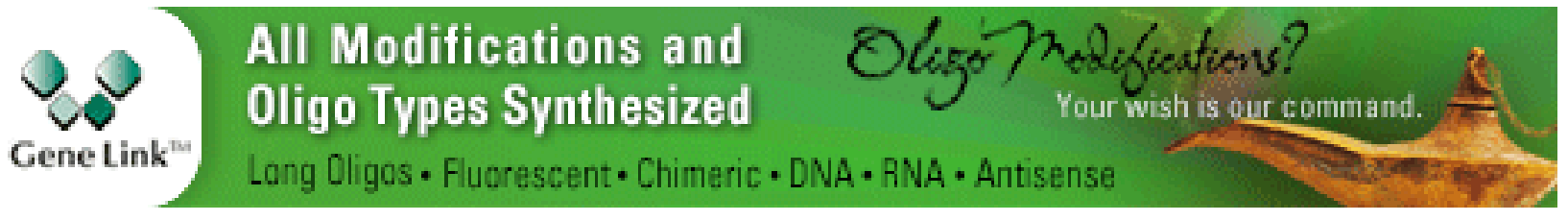

Copyright @ 2020 Cold Spring Harbor Laboratory Press; all rights reserved 